\title{
Remote Sensing of Global Croplands for Food Security
}

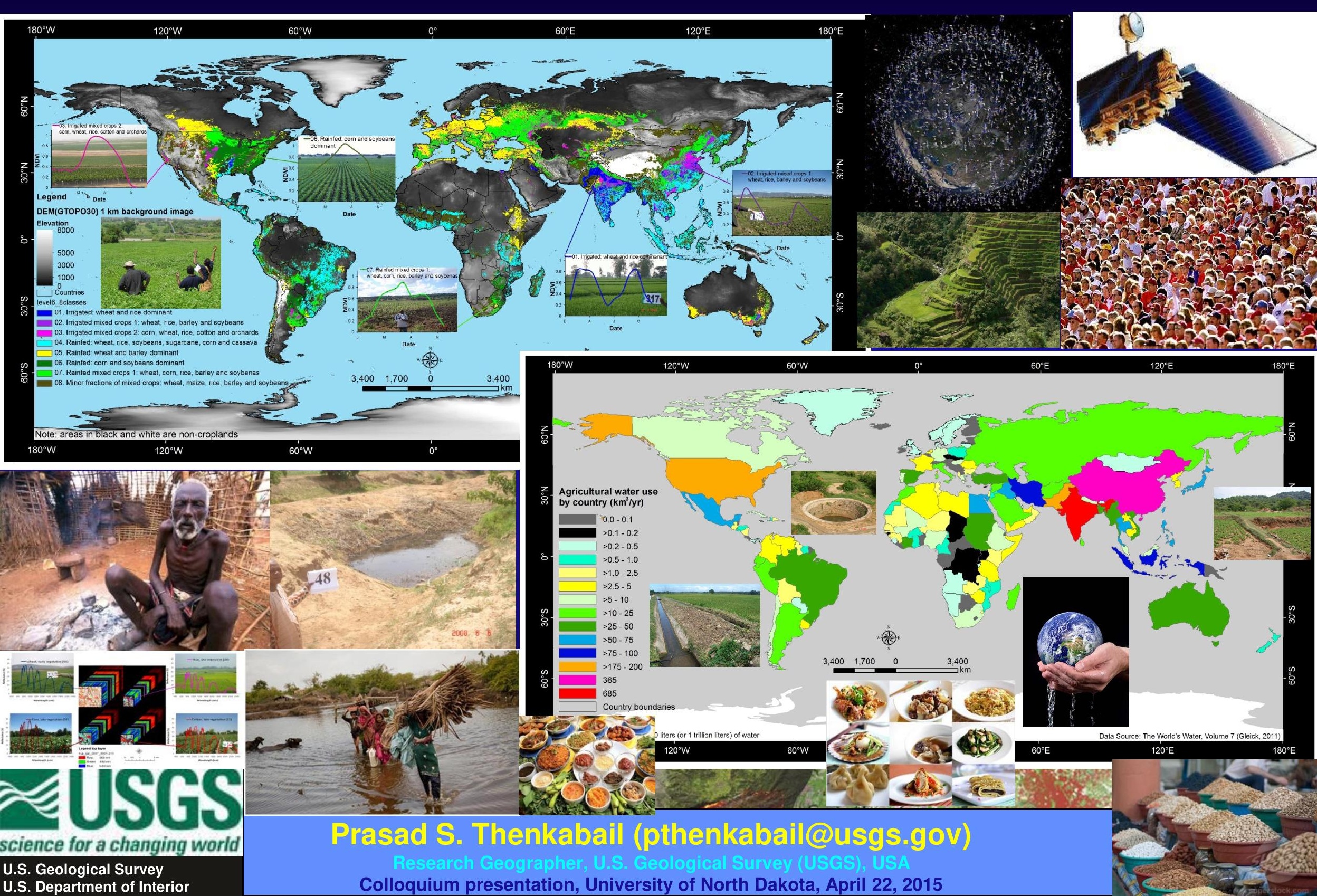




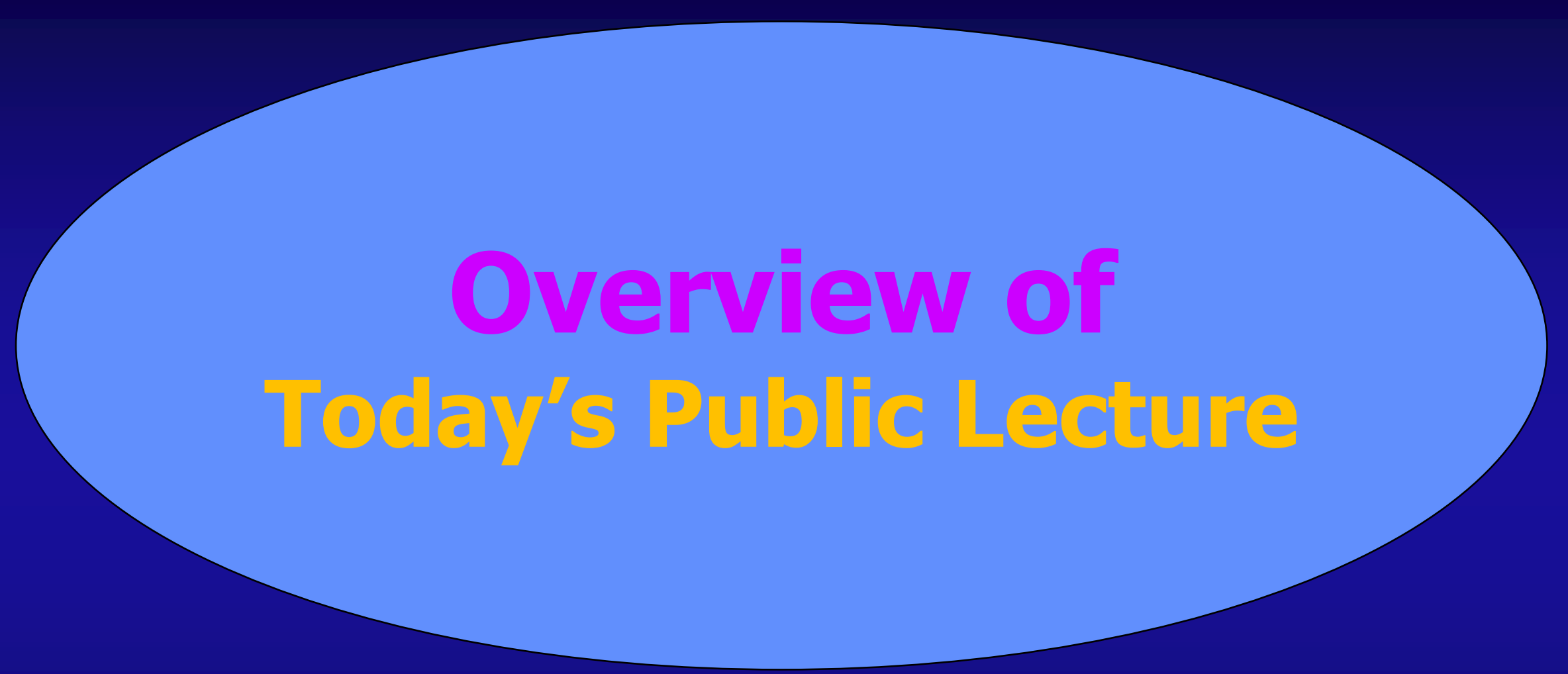

$\approx$ \#SGS

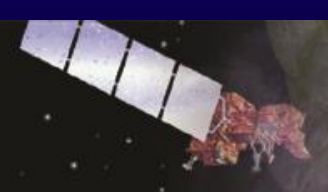

S. Geological Survey

U.S. Department of Interior 
Global Food Security in the $21^{\text {st }}$ Century: Increasing Need of Cropland Areas and Agriculture Water for Food Security

\section{Overview of Today's Lecture}

1. Context

2. Looking Back: How did we manage all these years?

3. Looking ahead: Big issues of Food Security in the 21 st Century

4. Why "Business as Usual" is not a solution anymore

5. Setting the Stage: New paradigm for ensuring global food security 5.1 Role of Global Croplands and Earth Observation (EO) Data 5.2 Role of Global Cropland Water Use and EO Data

6. Solutions and Way Forward

7. Refierences

$\approx$ USGS

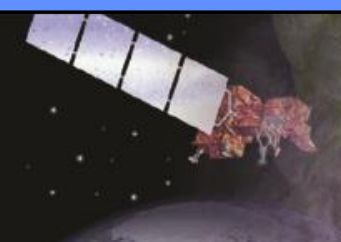




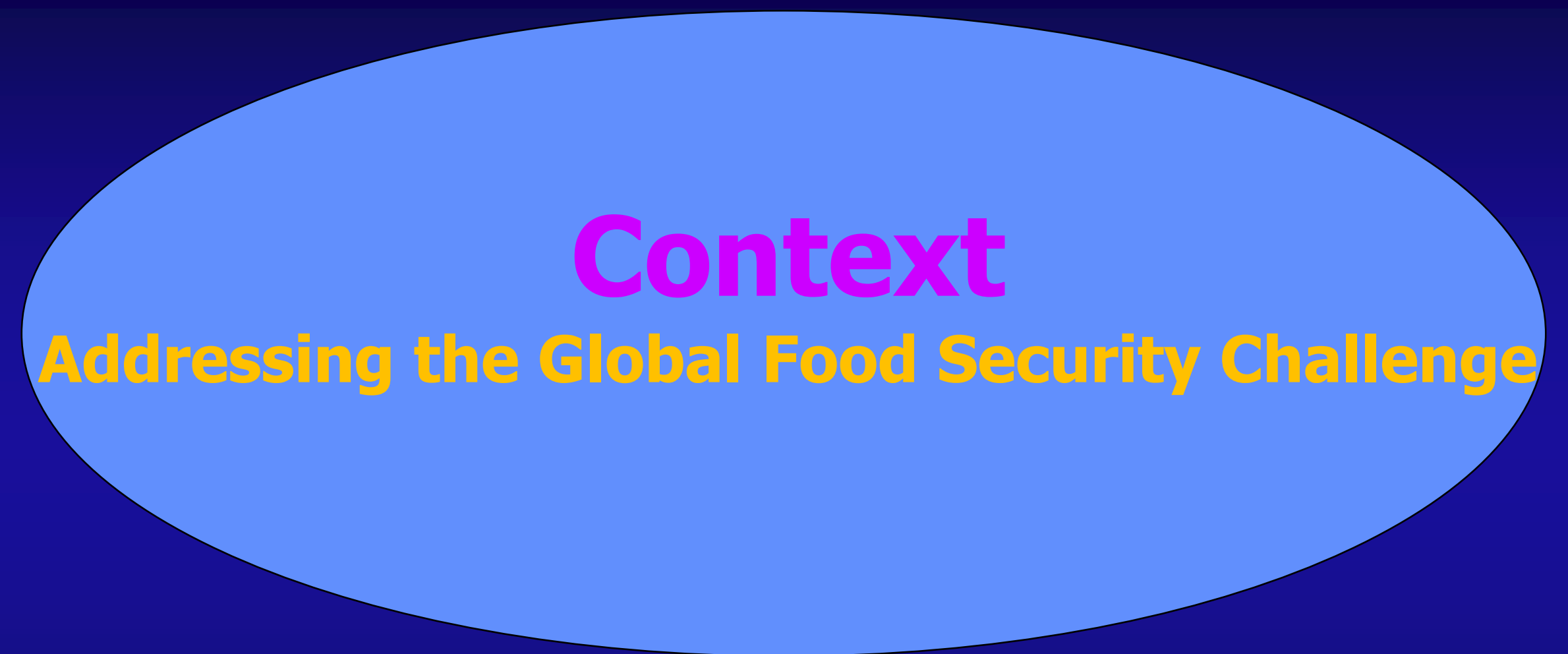

$\approx$ \#SGS

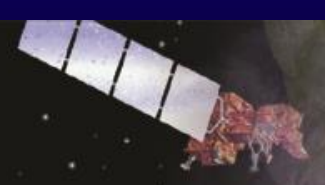

S. Geological Survey

U.S. Department of Interior 
Global Food Security in the $21^{\text {st }}$ Century: Increasing Need of Cropland Areas and Agriculture Water for Food Security

\section{Context: Big Picture}

Key components, issues, and questions pertaining to Global Food Security

In a World of limited resources pertaining to

Cropland Areas: $12 \%$ croplands; $24 \%$ grazing lands;

Water Resources: 92\% water use for agriculture;

And a World of ballooning

Populations: 9.4 billion by 2050

And a World where there is an urgent need to preserve

Environments: 400 ppmv in 2014;

Flora/Fauna or Biodiversity: fast dwindling;

And a World where resource demands for other needs increase

Urbanization

Industry, Trade, and the complexity of a virtual world

Environmental flows

Health and recreation

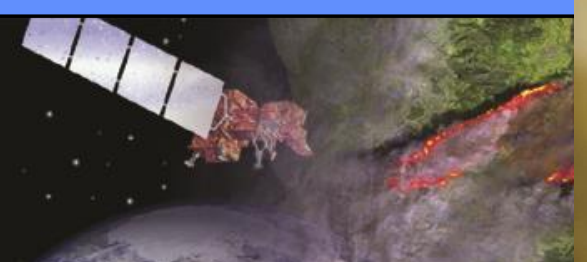

$\mathrm{CO}_{2}$ Hits Climate Milestone First Full Month with Levels Above 400 ppm

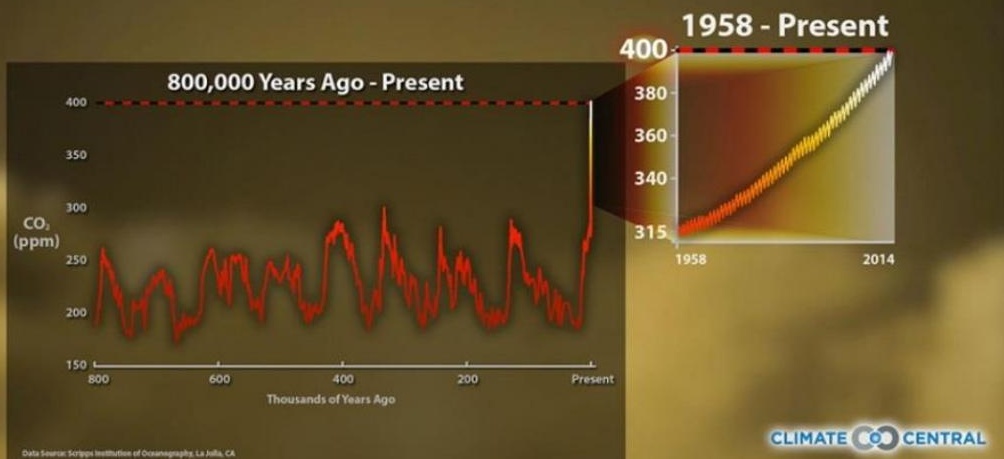




\section{Context: Current Picture (e.g., 2012 Drought|Climate Variability)}

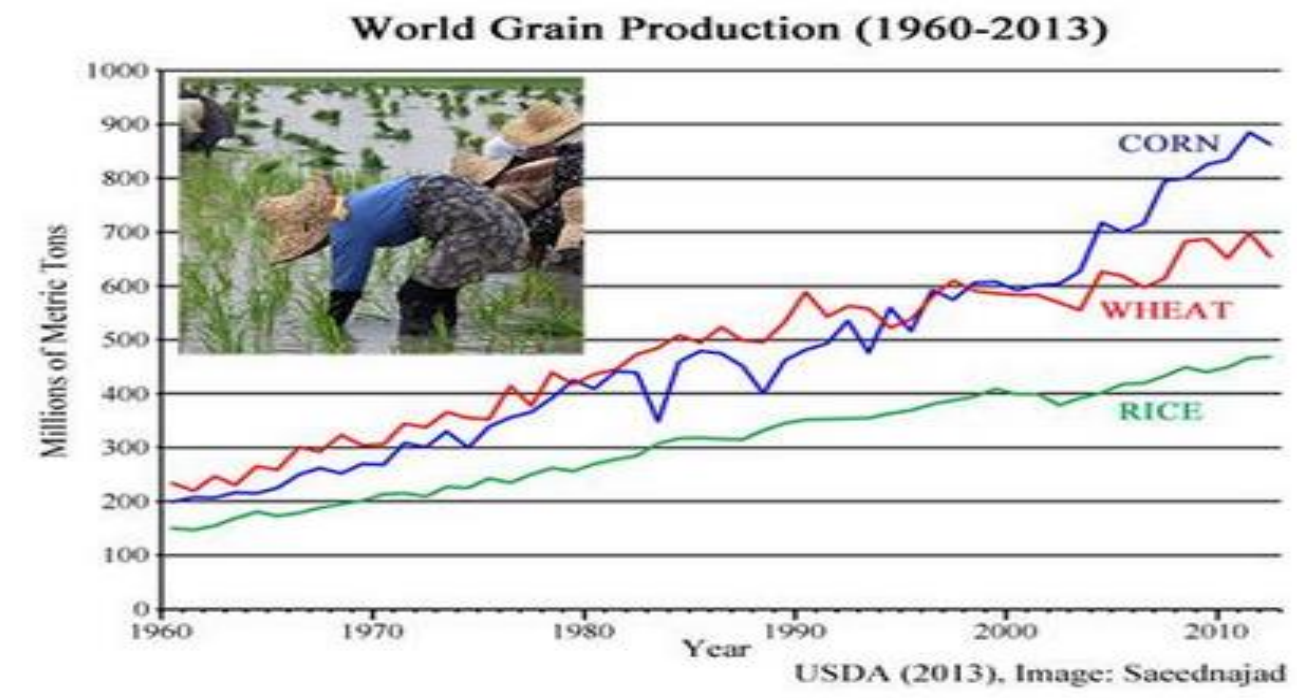

\section{U.S. Drought Monitor}
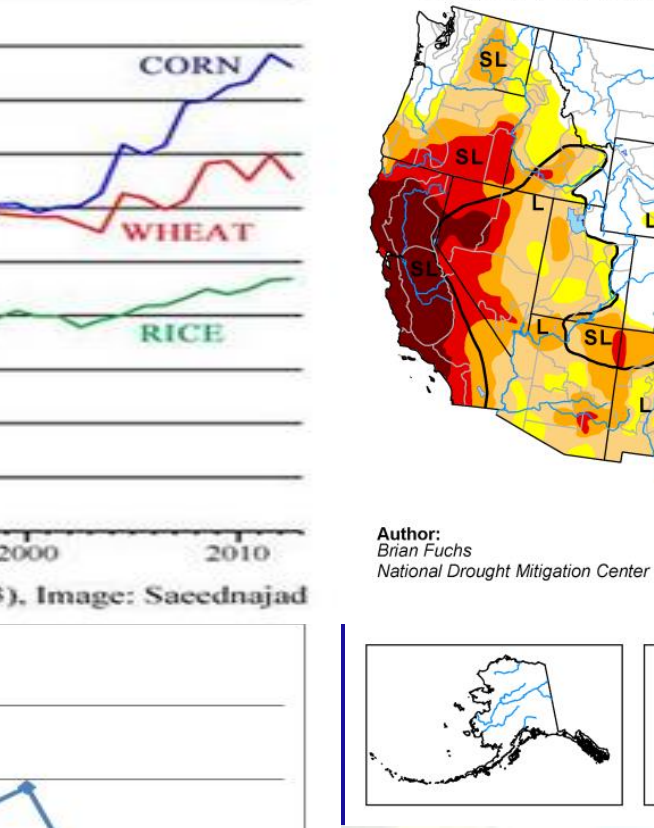

US Corn Prices Since 2004

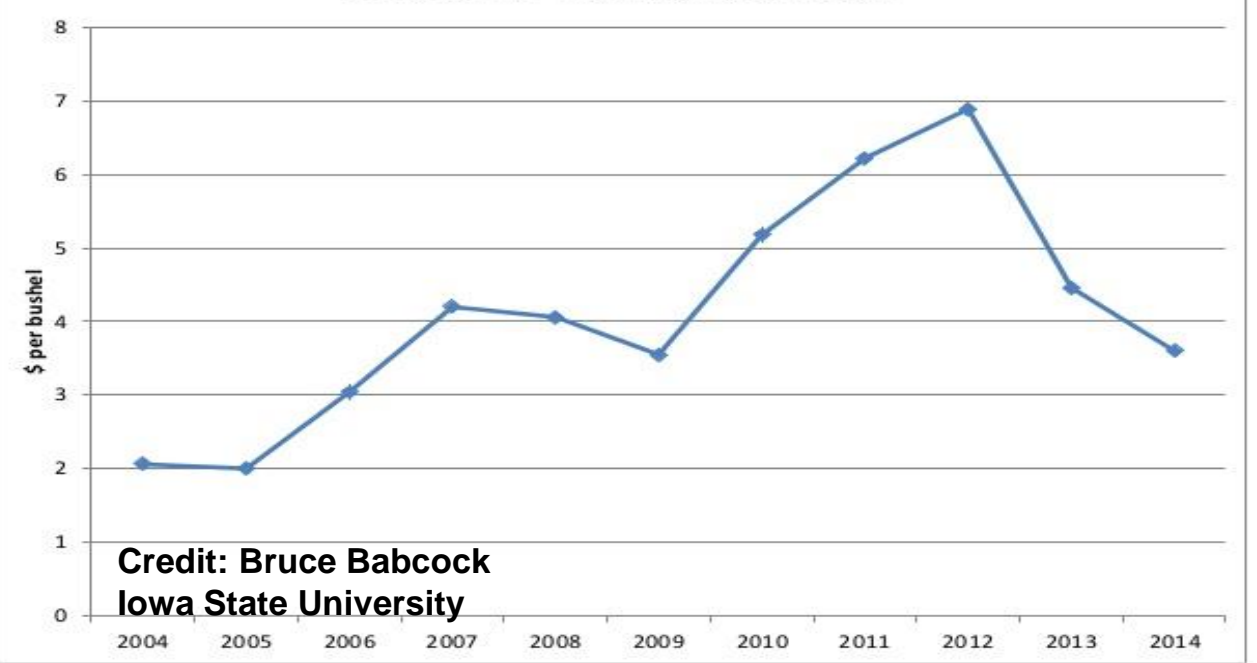

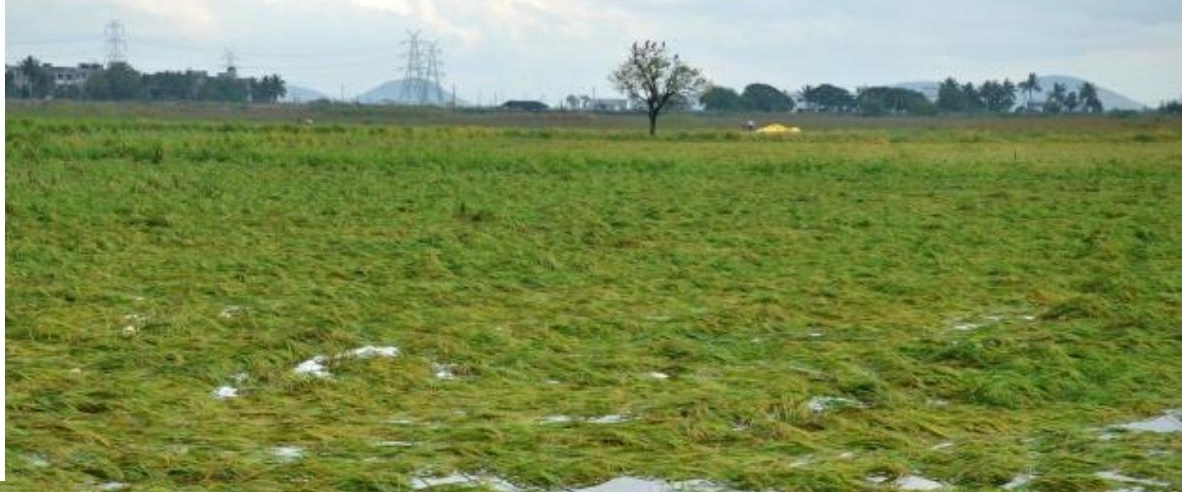

India got 48 year recordunseasonal rains in March, 2015 resulting in crop damage of about 200 million US dollars

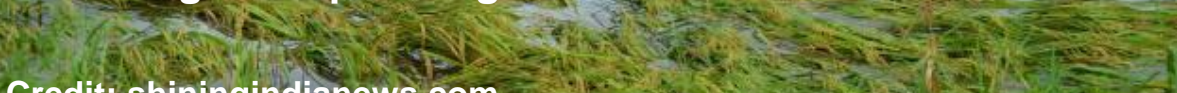
Credit: shiningindianews.com

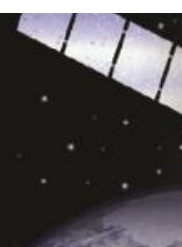

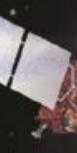

October 28, 2014

(Released Thursday, Oct. 30, 2014) Valid 8 a.m. EDT

$\sim$ Delineates dominant in

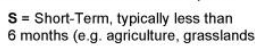
$L=$ Long- - Term, typically greater than
6 monthts (e. hy hyrology, ecology) Intensity Do Abnormally Dry
D1 Moderate Prought
D2 Severe Drought D2 Severe Drought
D3 Exreme Drought
D4 Exceptional rrought

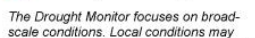

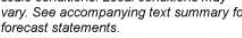
USDA $\simeq$ बiser http://droughtmonitor.unl.edu/ 
Global Food Security in the $21^{\text {st }}$ Century: Increasing Need of Cropland Areas and Agriculture Water for Food Security Context: How Does Climate Variability Influence Food Production

1. Will there be enough water to grow food?;

2. Will the water be available when it is needed (e.g., during the growing period)?;

3. What happens if the fertile croplands are taken for urban development?

4. Can we grow enough food by addressing environmentallhealth concerns?

Source: Future drought conditions, courtesy of Aiguo Dai/Wiley Interdisciplinary Reviews.
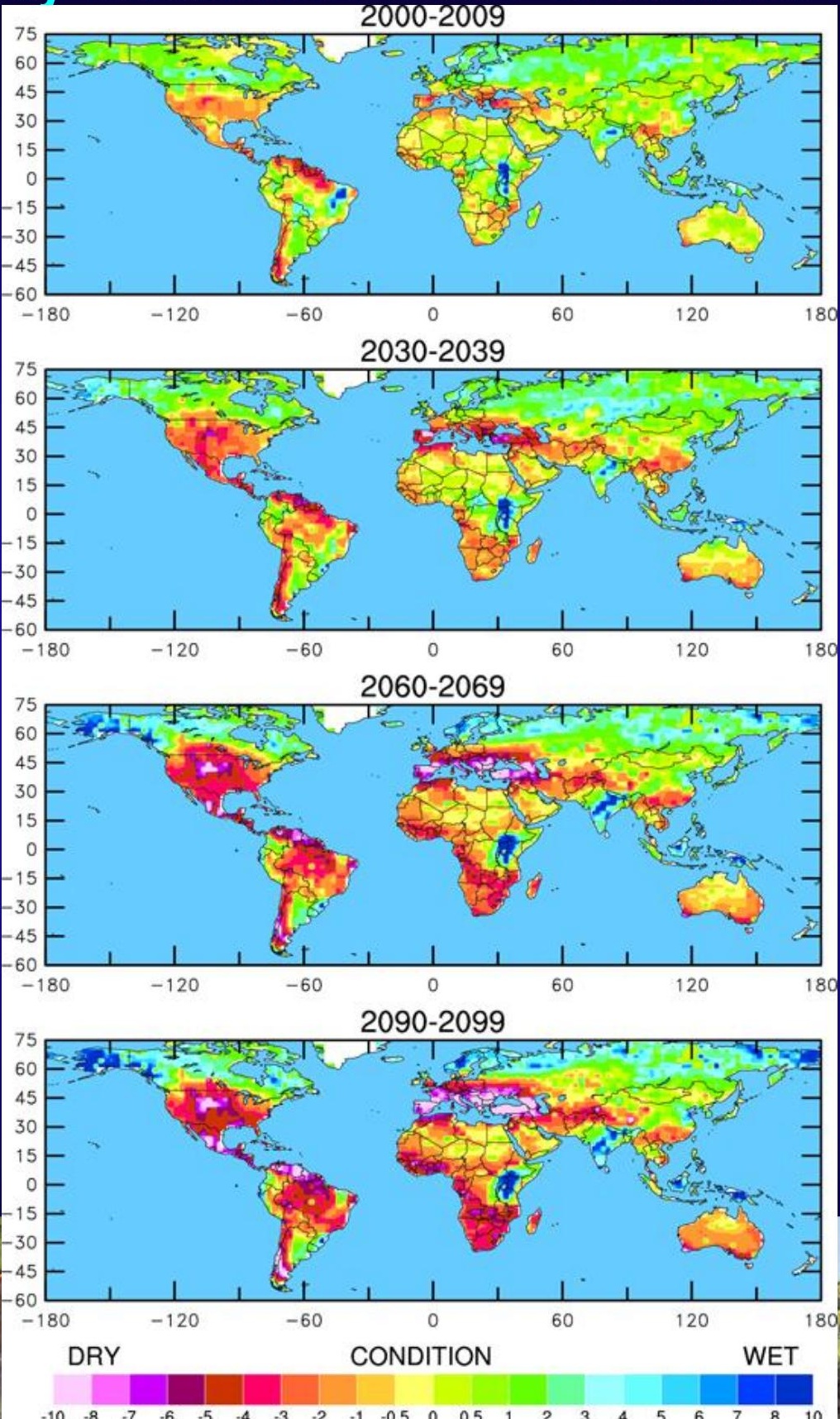


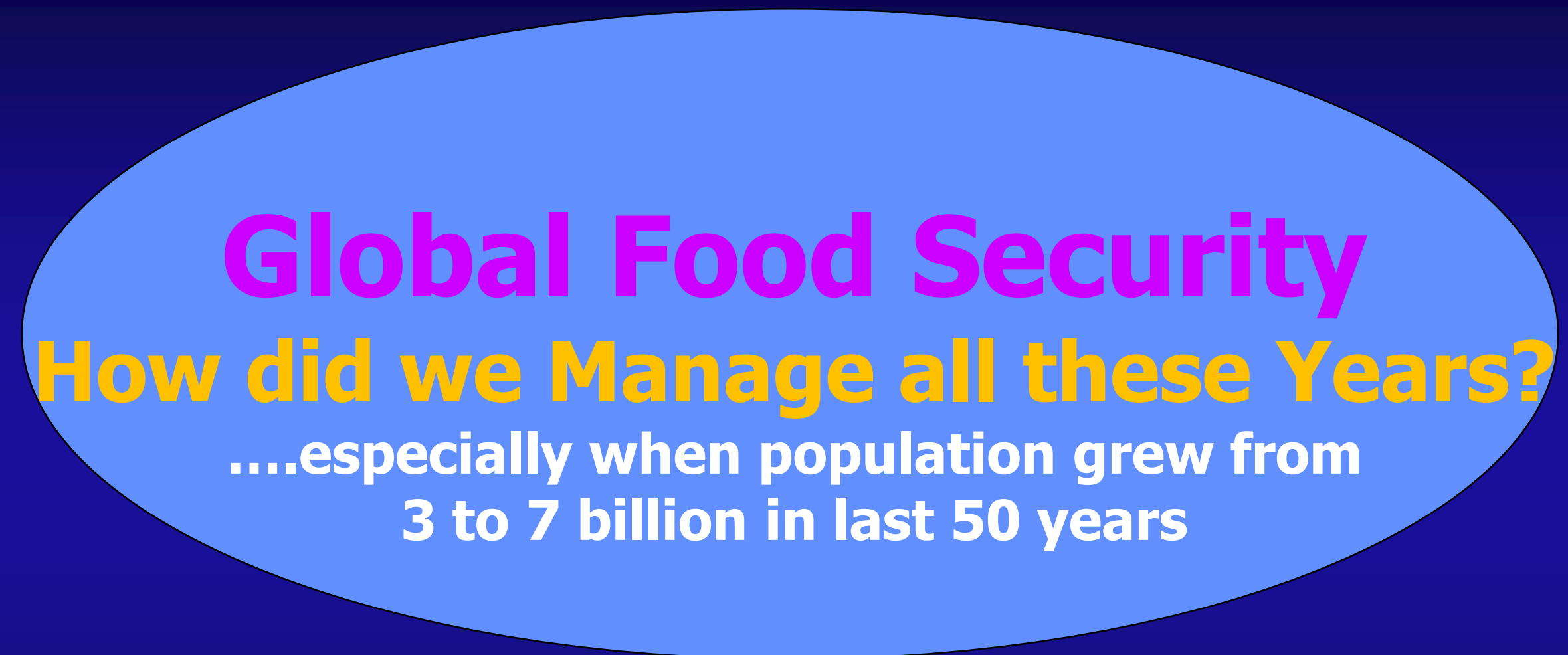

$\approx U S G S$

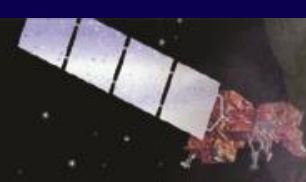

U.S. Geological Surve

U.S. Department of Interior 
Global Food Security in the 21 $1^{\text {st }}$ Century: Increasing Need of Cropland Areas and Agriculture Water for Food Security How Did we Feed the World between 1960-present: Green Revolution was Key when world added an additional 4 billion people in just 50 years!
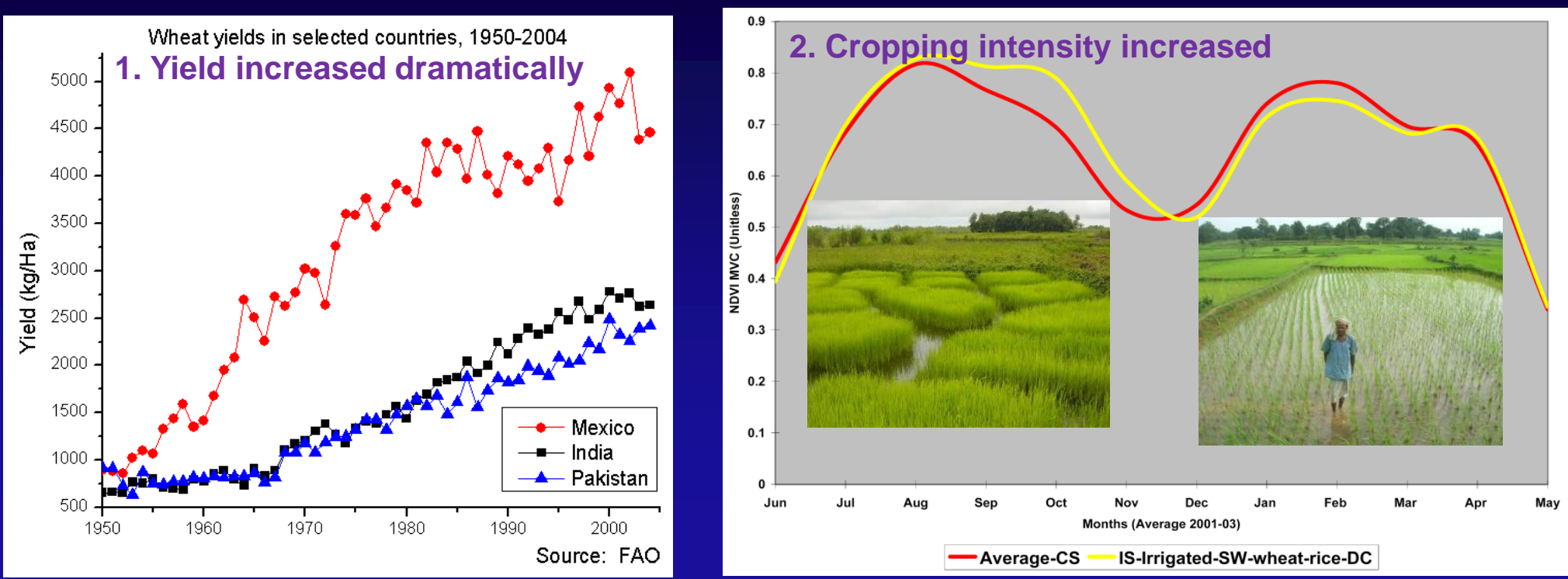

3. Irrigation took over

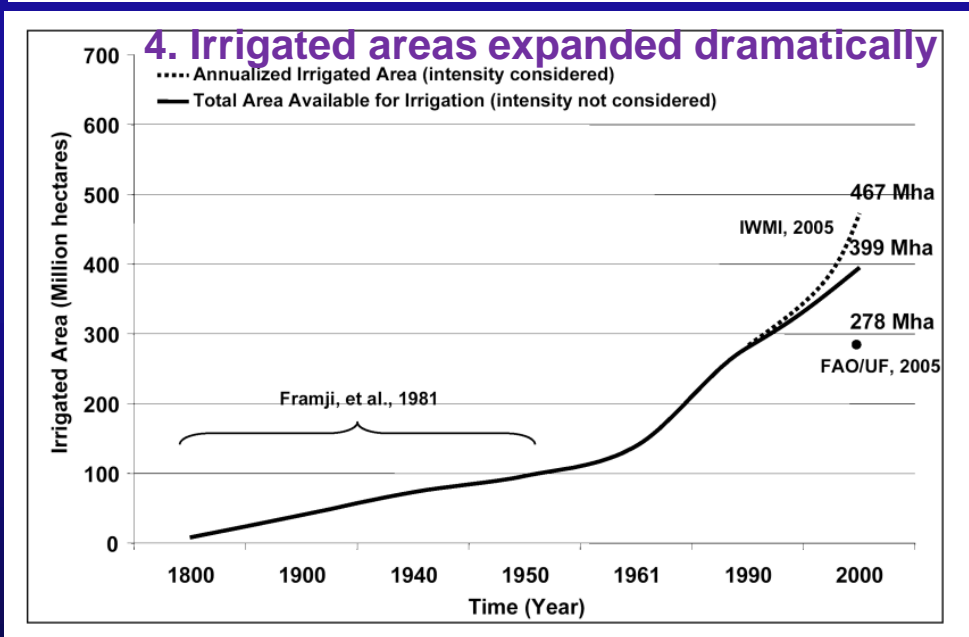

....also

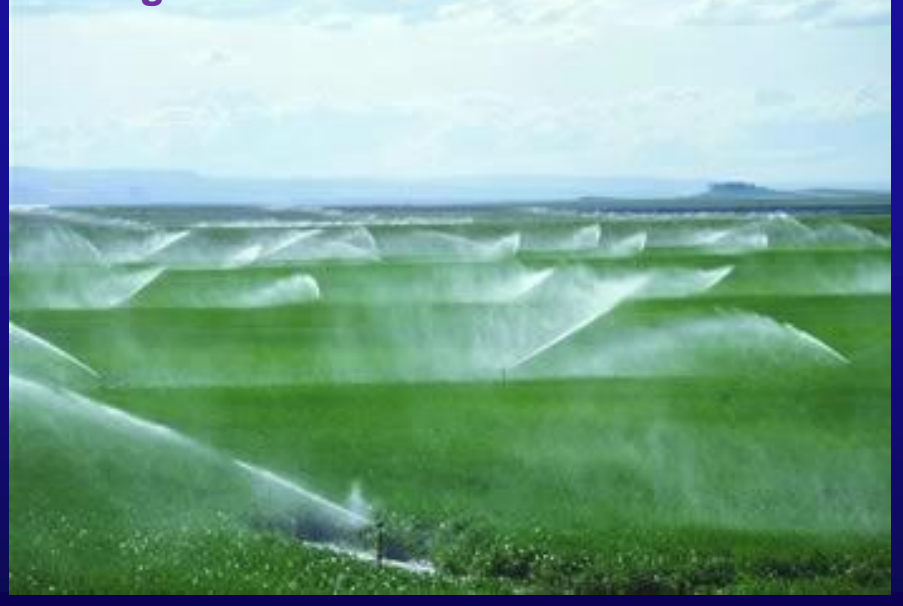
cropland management involving herbicides, pesticides, fertilizers, drainage....... combination of these factors lead to green revolution
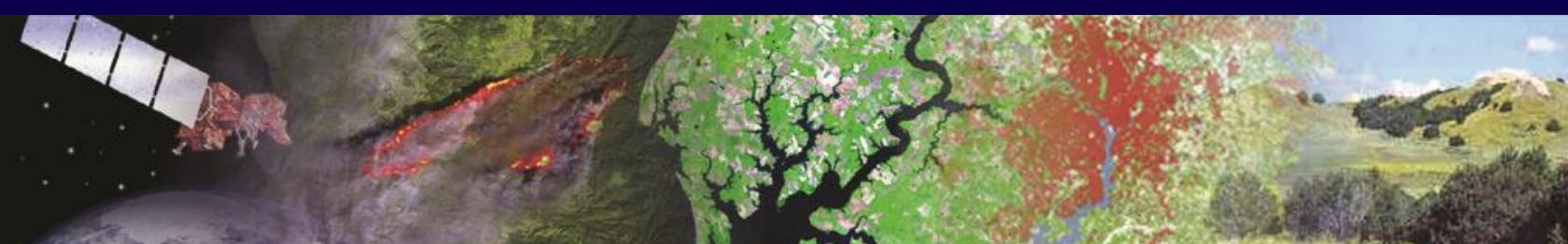


\section{U.S. Corn: Yield per Acre} 1866 to 2010

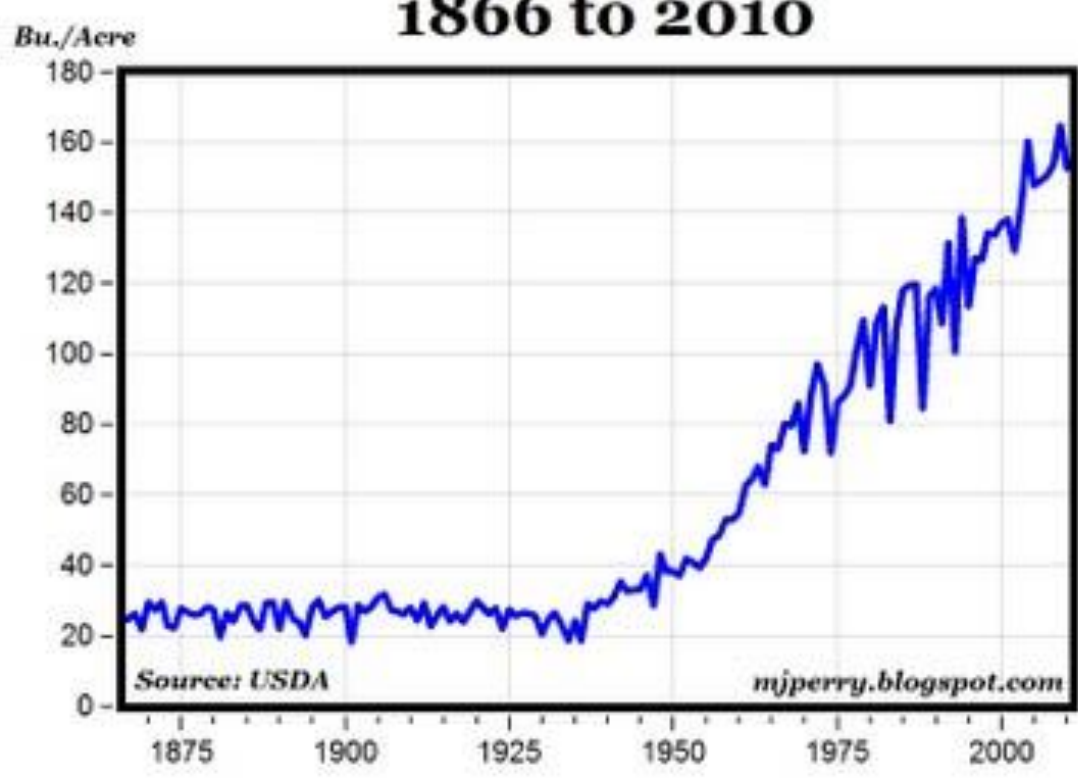

Source: USDA NASS
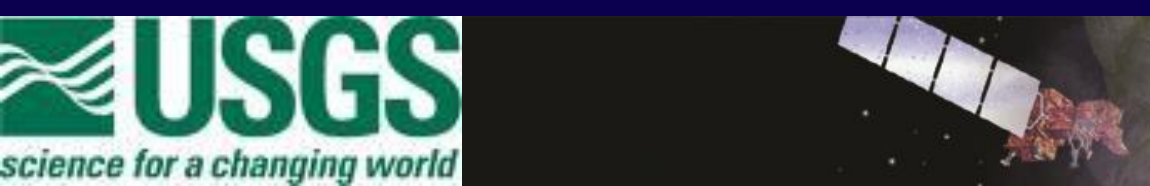

In the United States, for Example, Key Crop Yields increased by 300 to $400 \%$ during Green Revolution Era

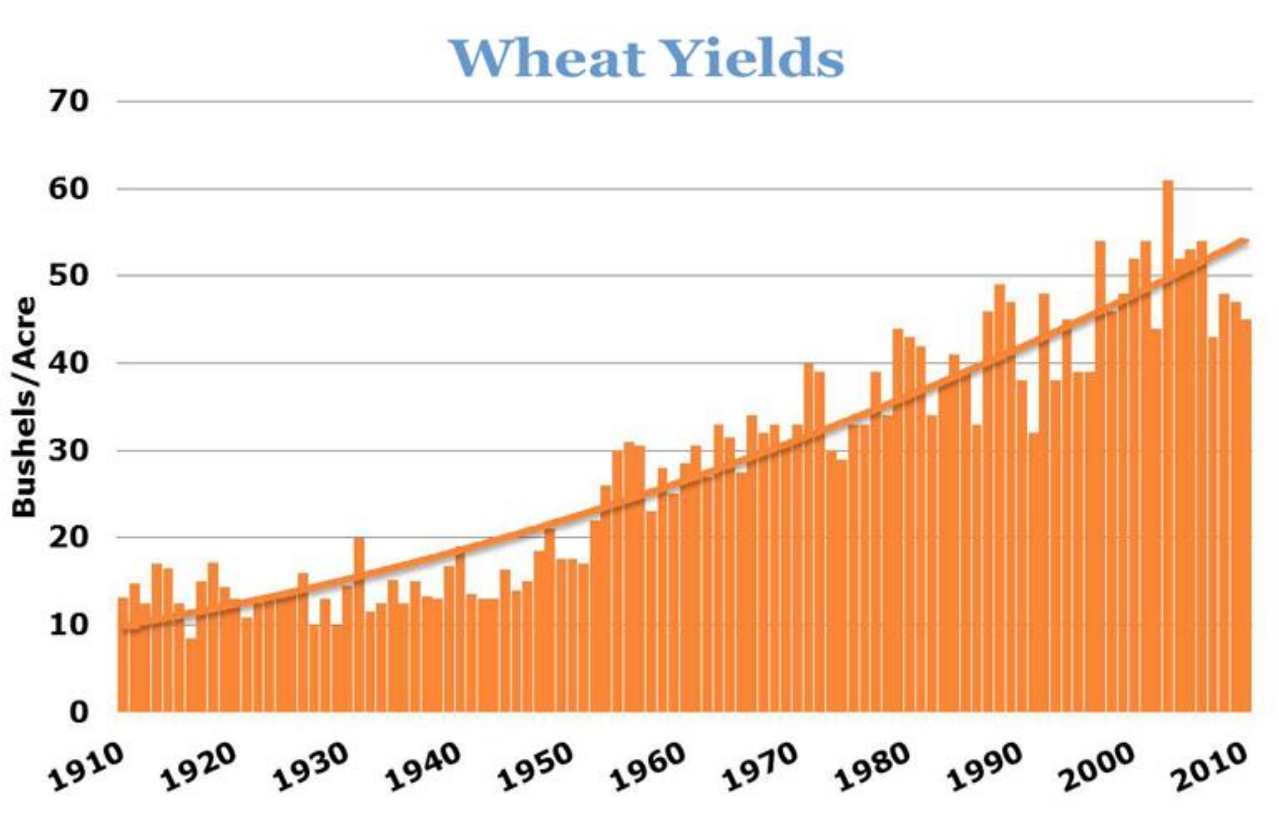


Global Food Security in the 21 $1^{\text {st }}$ Century: Increasing Need of Cropland Areas and Agriculture Water for Food Security Green Revolution: Increases in Productivity per Unit of Land between 1950-2010

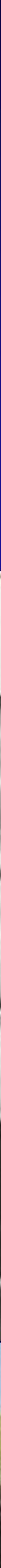




\section{Global Food Security in the 21 $1^{\text {st }}$ Century: Increasing Need of Cropland Areas and Agriculture Water for Food Security \\ Global Food Production During the Green Revolution Era}

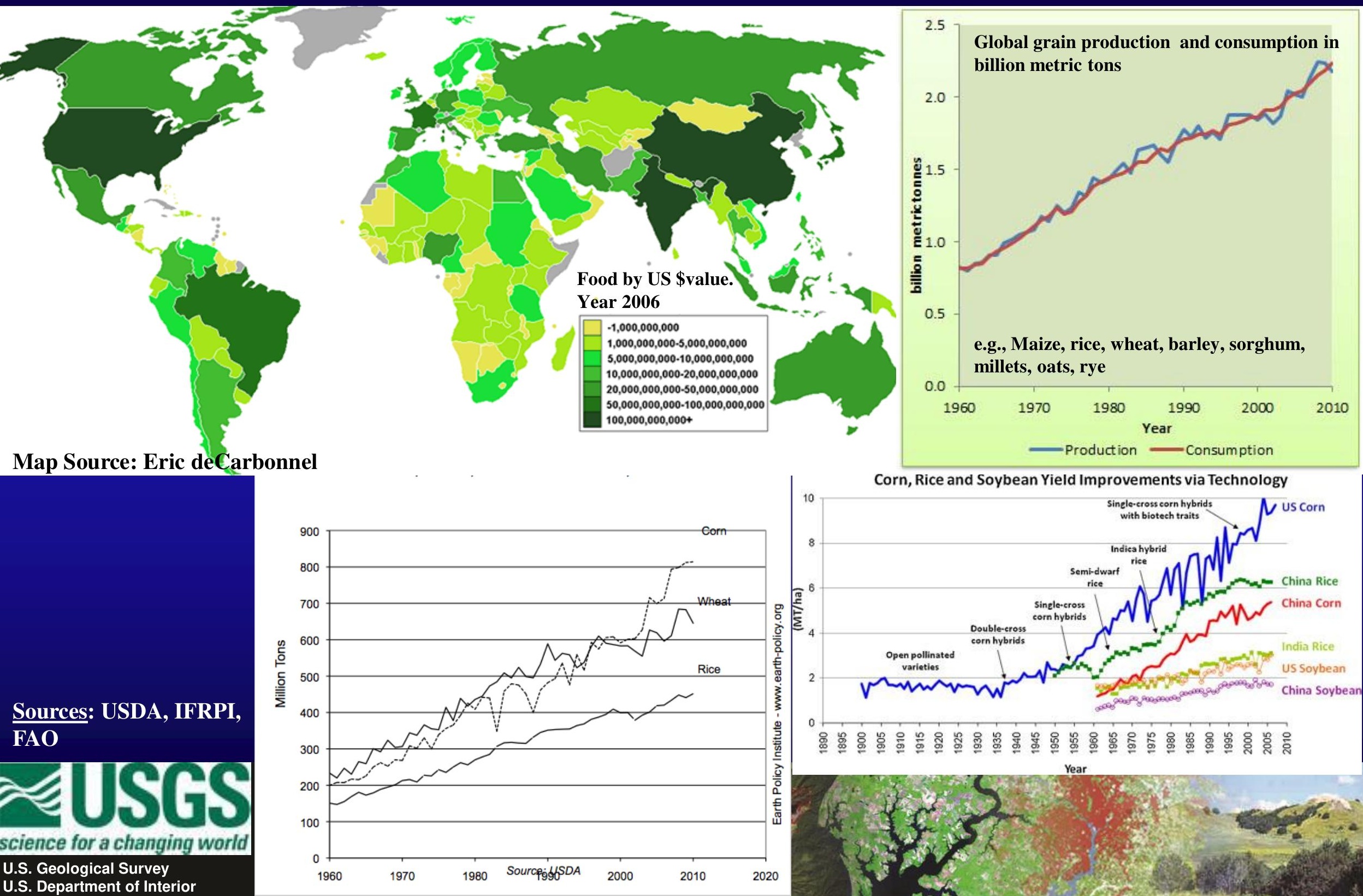


Global Food Security in the 21 ${ }^{\text {st }}$ Century: Increasing Need of Cropland Areas and Agriculture Water for Food Security Global Food Security during the Green Revolution Era ( 1960-2010)

\section{In the last 50 years population which grew 3 billion in year 1960 to 7.3 billion in year The food demands of this ballooning population was met by:}

Green Revolution

"Almost certainly, however, the first essential component of social justice is adequate food for all mankind" - Norman Borlaug, Nobel laureate and Father of Green Revolution

"Peace can only last where human rights are respected, where the people are fed, and where individuals and nations are free." The $14^{\text {th }}$ Dalai Lama

"Food security is fundamental for human welfare, human advancement, and human dignity" Mahatma Gandhi

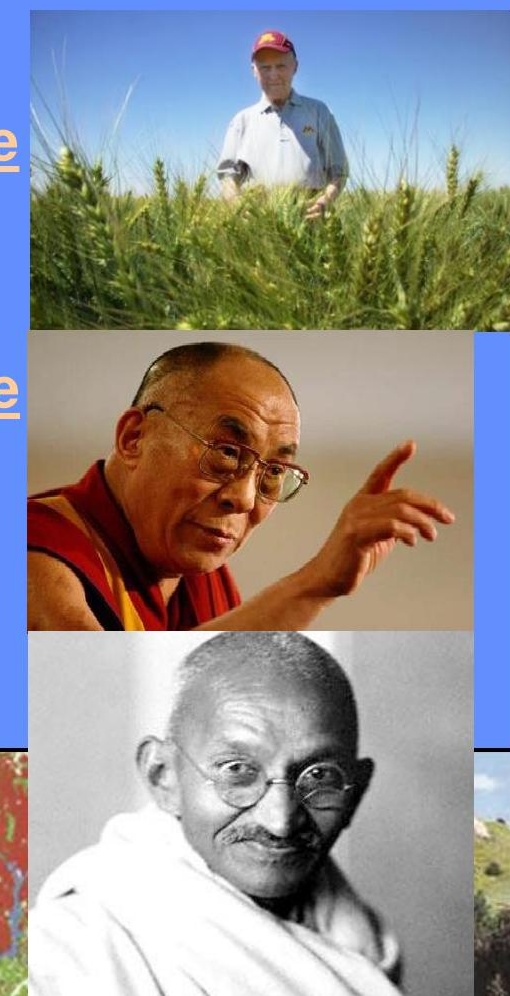




\section{Undernourished versus Overnourished}

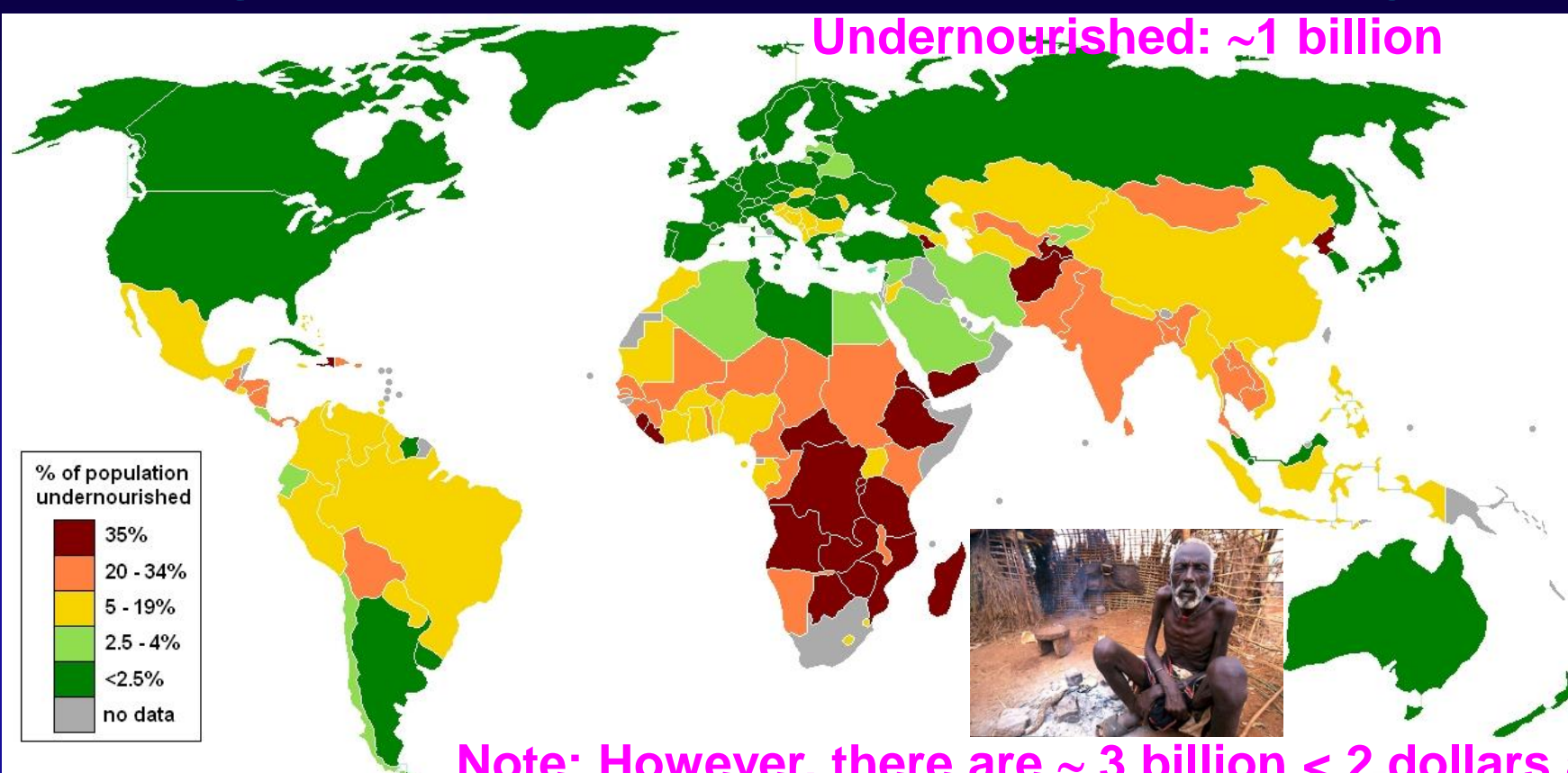

Undernourishment in 2010, by region (millions)

Note: However, there are $\sim 3$ billion $<2$ dollars a dav
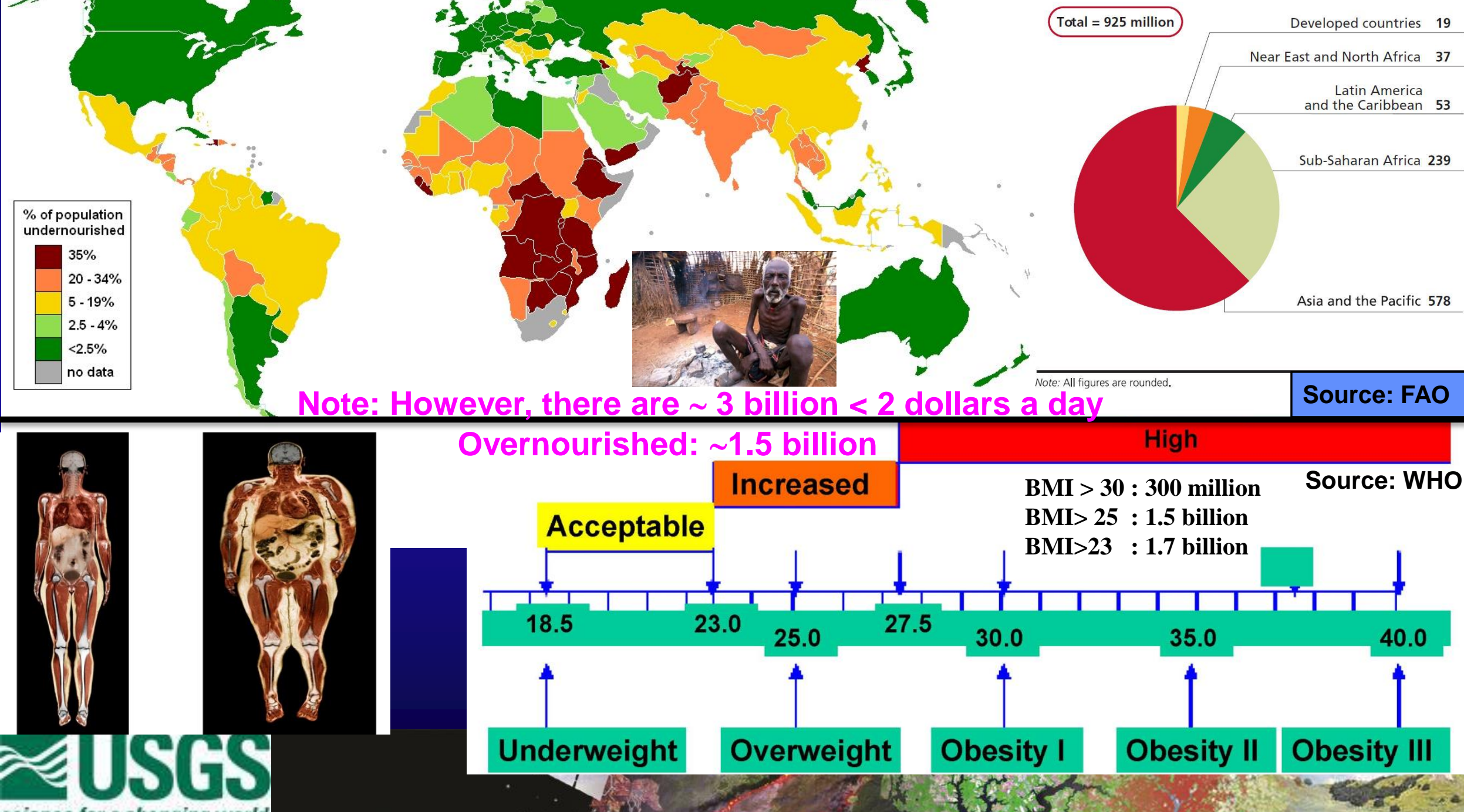

Overnourished: 1.5 billion Increased

High

science for a changing world

S. Geological Survey

U.S. Department of Interior

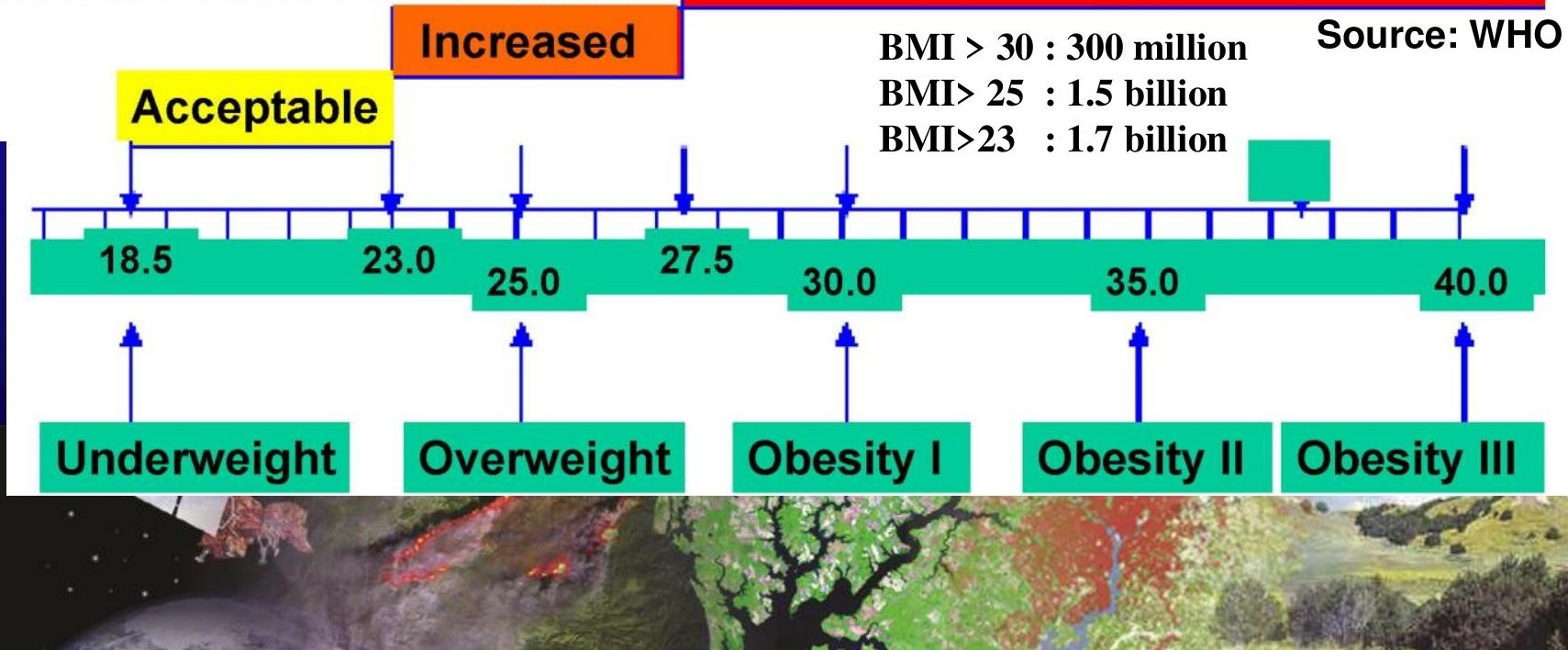




\section{Global Food}

Security

So What are the Big Issues in Years ahead?

....especially when population will grow from

7 to 9 or 10 billion in next 50 years

$\approx$ USGS

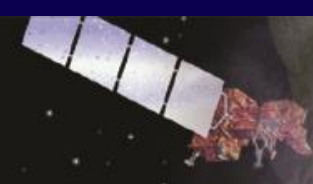

U.S. Geological Survey

U.S. Department of Interior 


\section{Current Global Population Density (people/km²)}

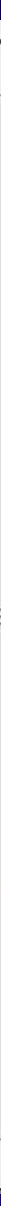

Source: LandScan 2007 from Oak Ridge National Laboratory and Gridded Population of the World v 3.0 from the NASA -funded Socioeconomic Data and Applications Center at the Center for International Earth Science Information Network.

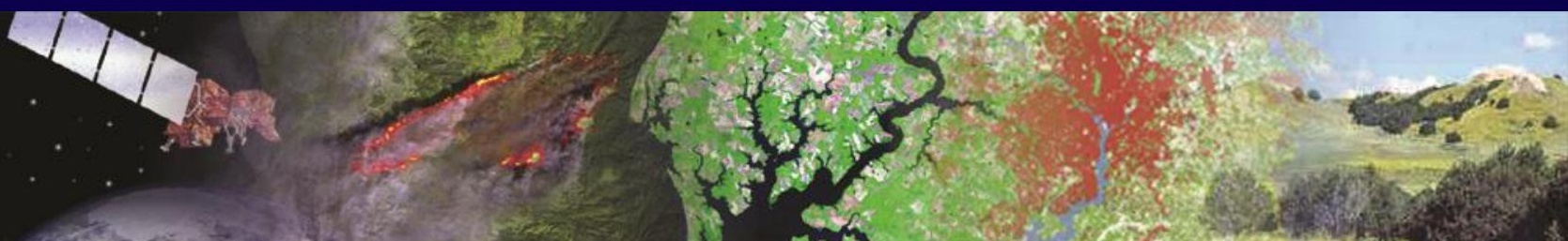




\section{Projected Global Population Scenarios: Variants}

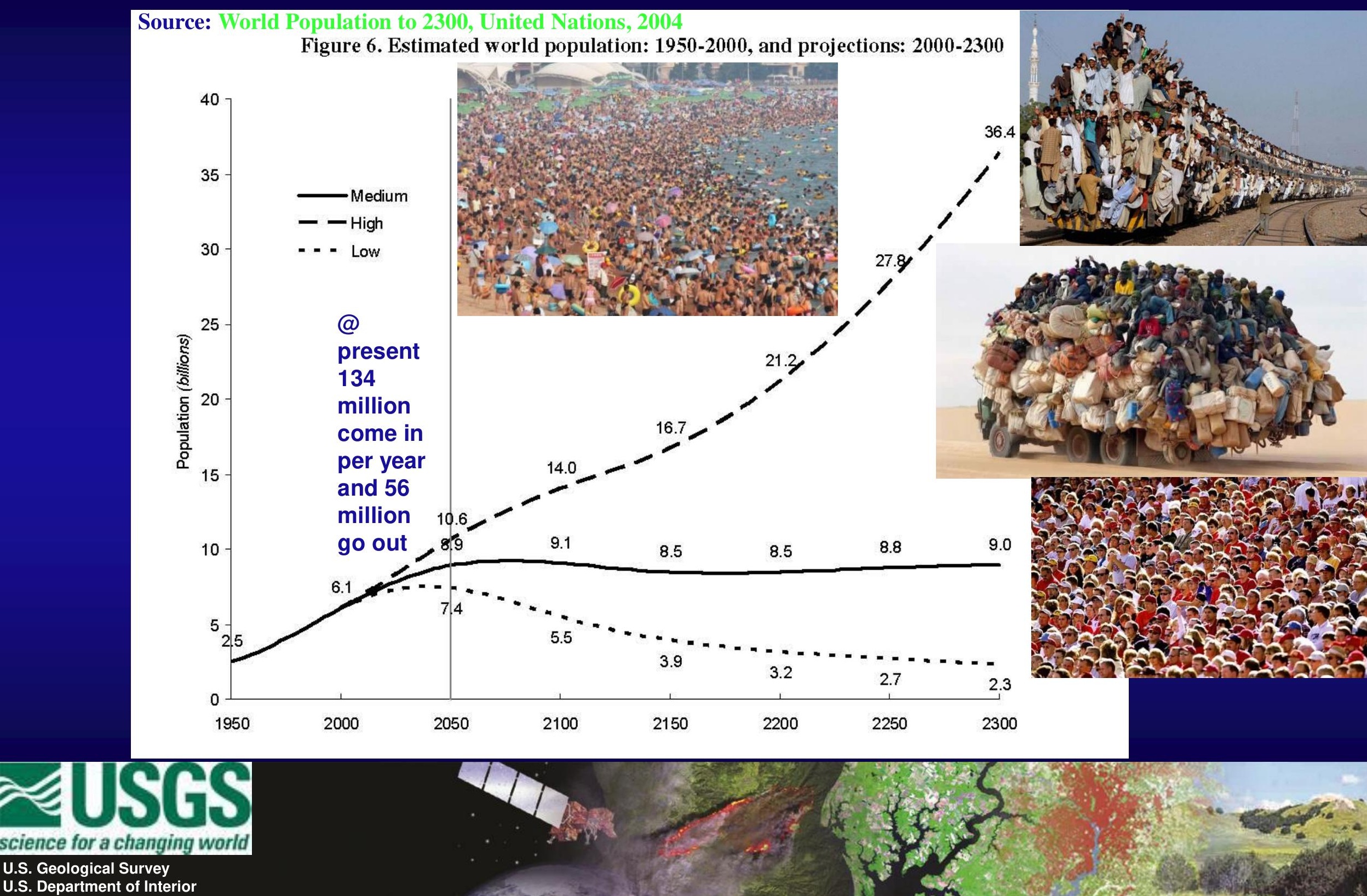


Global Food Security in the 21 ${ }^{\text {st }}$ Century: Increasing Need of Cropland Areas and Agriculture Water for Food Security

\section{Global Population Growth Simulation: 1950 through 2100}

\section{World Population 1950}

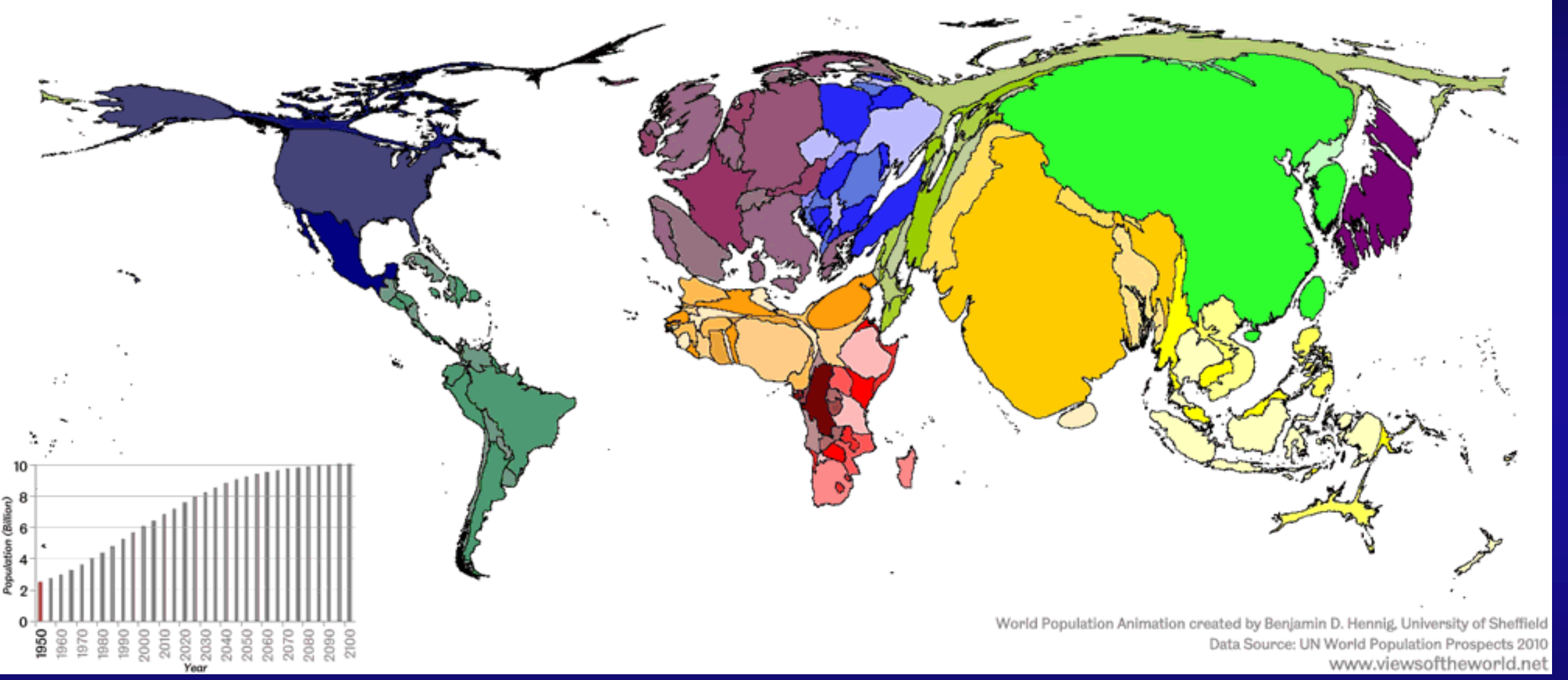

$\approx U S G S$

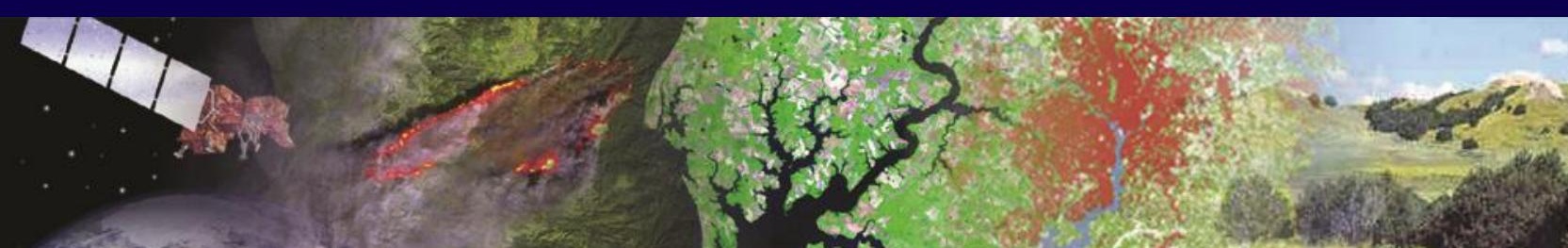

U.S. Geological Survey

U.S. Department of Interior 


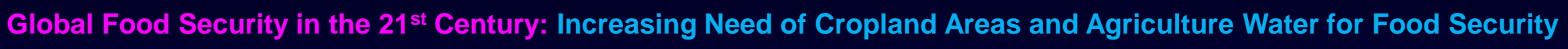

\section{Population Dynamics Scenario: 1950-2300}

\begin{tabular}{|l|l|l|l|l|l|}
\hline & Year & Year & Year & Year & Year \\
\hline & 1950 & 2000 & 2050 & 2100 & 2300 \\
\hline & Millions & Millions & Millions & Millions & Millions \\
\hline Japan & 84 & 127 & 109 & $* *$ & $* *$ \\
\hline & & & & & \\
\hline Germany & 68 & 82 & $* *$ & $* *$ & $* *$ \\
\hline United Kir & 50 & $* *$ & $* *$ & $* *$ & $* *$ \\
\hline Russia & 102 & 145 & 101 & $* *$ & $* *$ \\
\hline & & & & & \\
\hline USA & 157 & 285 & 408 & 437 & 493 \\
\hline & & & & & \\
\hline Brazil & 54 & 172 & 233 & 212 & 222 \\
\hline Mexico & 28 & 99 & 140 & 128 & 127 \\
\hline & & & & & \\
\hline Nigeria & 30 & 114 & 258 & 302 & 282 \\
\hline Ethiopia & $* *$ & 66 & 171 & 222 & 206 \\
\hline Congo DR & $* *$ & $* *$ & 151 & 203 & 183 \\
\hline Uganda & $* *$ & $* *$ & 103 & 167 & 155 \\
\hline Egypt & 22 & 68 & 127 & 132 & 125 \\
\hline & & & & & \\
\hline Yemen & $* *$ & $* *$ & 84 & 144 & 130 \\
\hline Iran & $* *$ & 66 & 105 & 98 & 101 \\
\hline & & & & & \\
\hline
\end{tabular}

$* * *$ Not in top 19 countries in the year

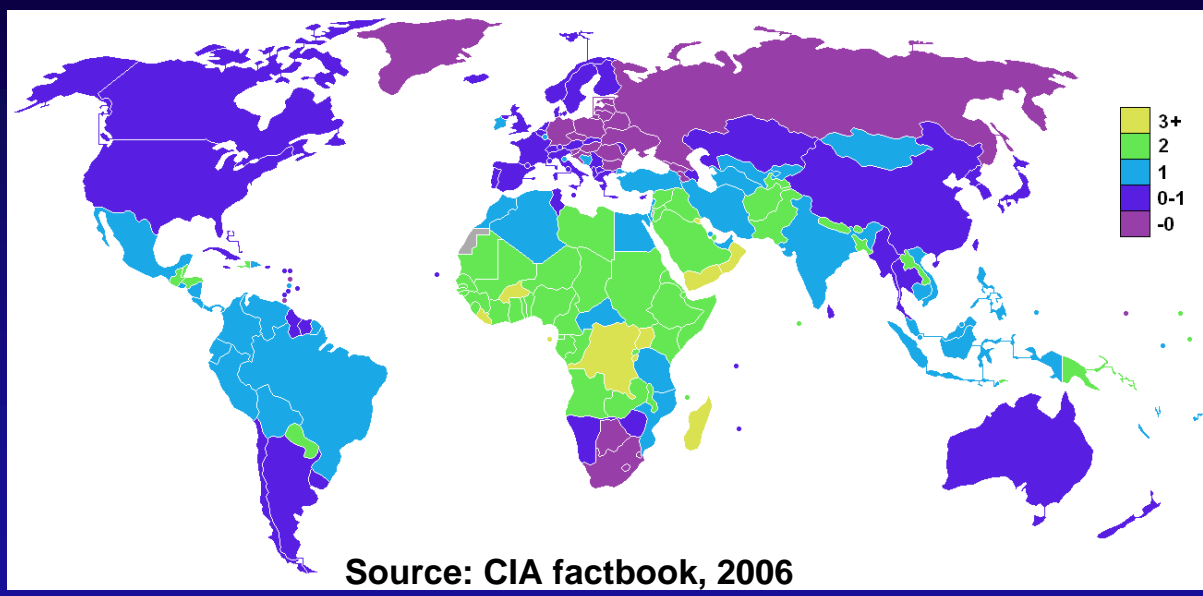

\begin{tabular}{|c|c|c|c|c|c|}
\hline & Year & Year & Year & Year & Year \\
\hline & 1950 & 2000 & 2050 & 2100 & 2300 \\
\hline & Millions & Millions & Millions & Millions & Millions \\
\hline China & 554 & 1275 & 1395 & 1181 & 1285 \\
\hline India & 357 & 1016 & 1531 & 1458 & 1371 \\
\hline Bangladesh & 42 & 138 & 254 & 260 & 242 \\
\hline Pakistan & 40 & 142 & 349 & 408 & 359 \\
\hline Indonesia & 79.5 & 211 & 293 & 272 & 276 \\
\hline Africa & 221 & 795 & 1803 & 2254 & 2112 \\
\hline Asia & 1398 & 3679 & 5222 & 5019 & 4943 \\
\hline Latin America and Carribean & 167 & 520 & 767 & 732 & 722 \\
\hline Oceania & 12.8 & 31 & 45.8 & 46.1 & 48.4 \\
\hline North America & 171 & 315 & 447 & 473 & 534 \\
\hline Europe & 547 & 728 & 631 & 538 & 611 \\
\hline Total & 2516.8 & 6068 & 8915.8 & 9062.1 & 8970.4 \\
\hline
\end{tabular}




\section{Daily Calories: A Global Picture}

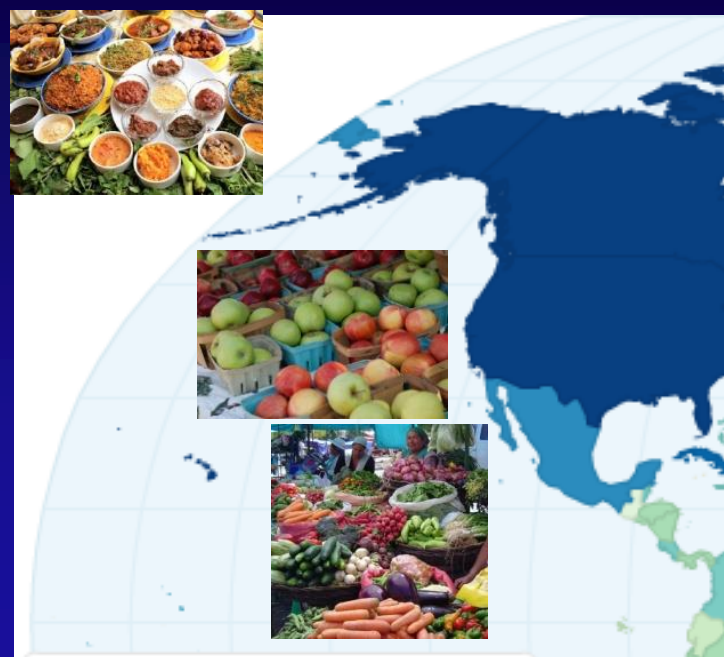

Daily Calorie Intake Per Capita

$\square$ Less than 1,890

$\square 1,890-2,170$

$\square 2,170-2,390$

$\square 2,390-2,620$

$\square 2,620-2,850$

$\square 2,850-3,050$

$\square 3,050-3,270$

$3,270-3,480$

$3,480-3,770$

$\square$ No data

in kcal/person/day

Source: FAO, 2010

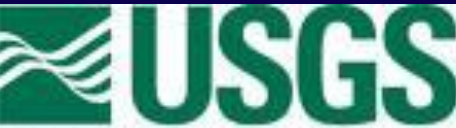

science for a changing world

U.S. Geological Survey

U.S. Department of Interior
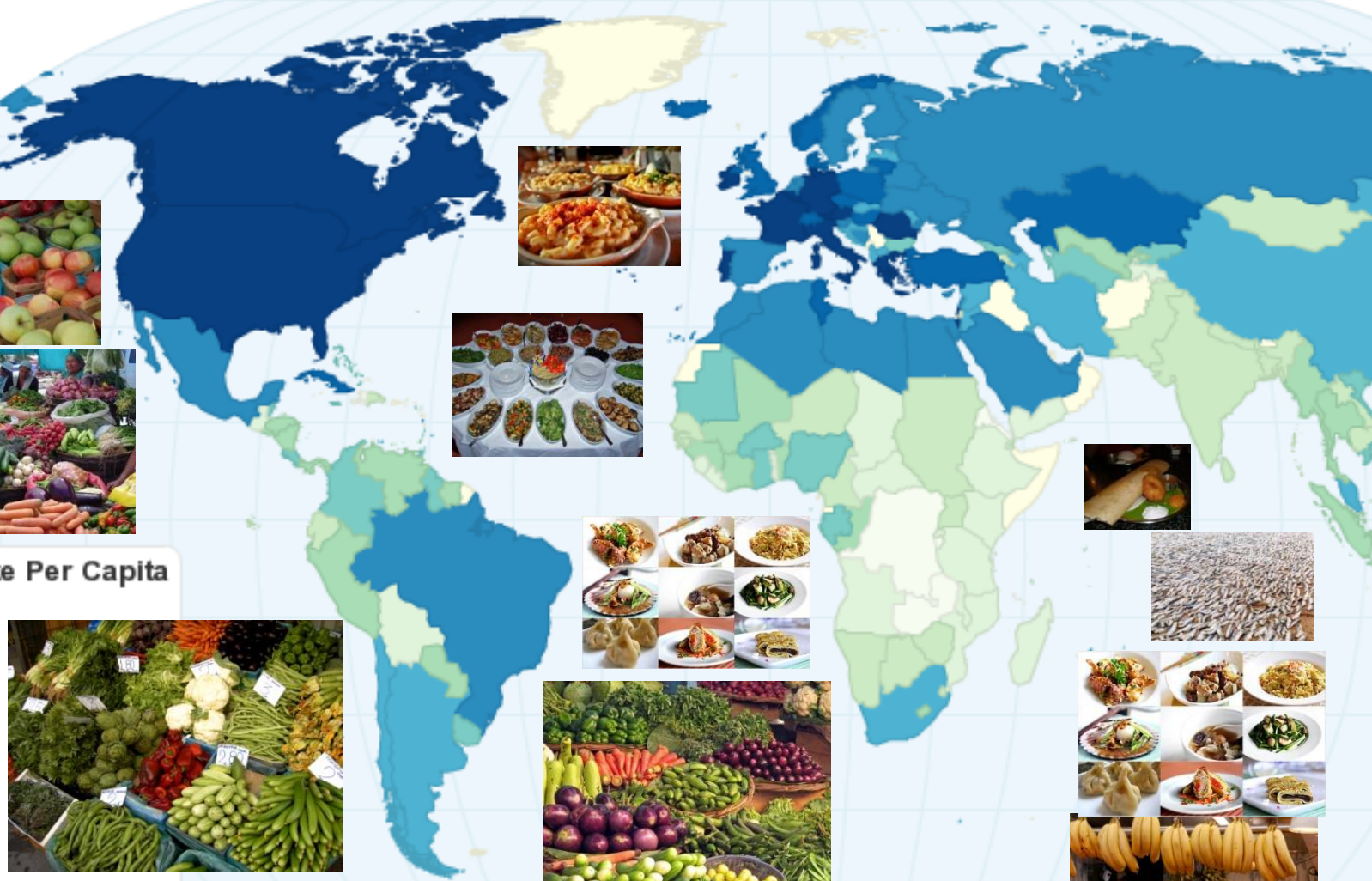

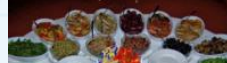 1.}

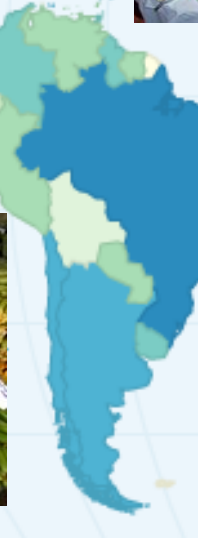

(a)

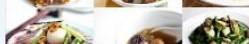
Qcoly Sep

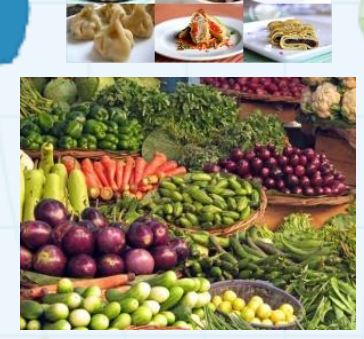

World: $2780 \mathrm{kcal} /$ person/day Developed countries: $3420 \mathrm{kcal} /$ person/day Developing World: $2630 \mathrm{kcal} / \mathrm{person} / \mathrm{day}$ Sub-Saharan Africa: 2240 kcal/person/day Central Africa: $1820 \mathrm{kcal} / \mathrm{person} / \mathrm{day}$

Kilocalorie: A unit of measurement of dietary energy. One kcal equals 1,000 calories and one $\mathrm{kJ}$ equals 1,000 joules. In the International System of Units (ISU), the universal unit of dietary energy is the joule (J). One $\mathrm{kcal}=4.184$ kJ.
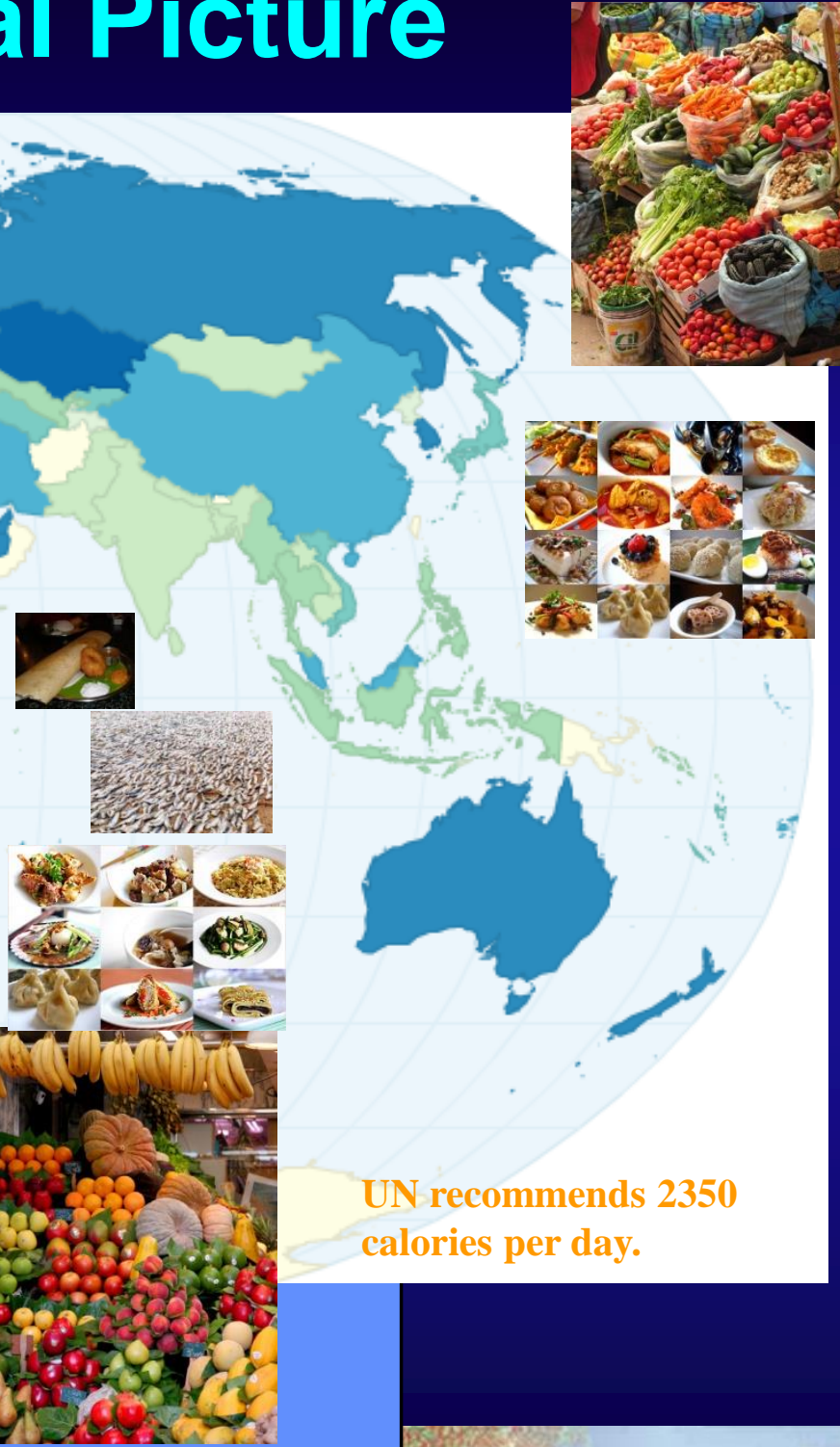

UN recommends 2350 calories per day.

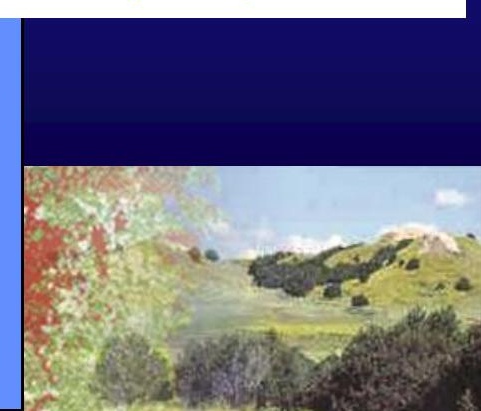


Global Food Security in the 21 $1^{\text {st }}$ Century: Increasing Need of Cropland Areas and Agriculture Water for Food Security

\section{Addressing the Global Food Security Challenge}

\section{Next 50 years World needs to meet}

the food demand of a population

which will grow from 7 bilion in year

2011 to 9 or 10 billion by 2050. Three

factors need to be noted:

1. Population growth (e.g., additional 2 to 3 billion);

2. Increasing nutritional demand (e.g., more meat);

3. Change in demographics (e.g., swift rise in population in Africa) 


\section{Global Food Security Why "business as usual" is not a solution}

Geological Survey

U.S. Department of Interior 


\section{Increasing Cropland Areas Difficult}

Ramankutty et al., 2002

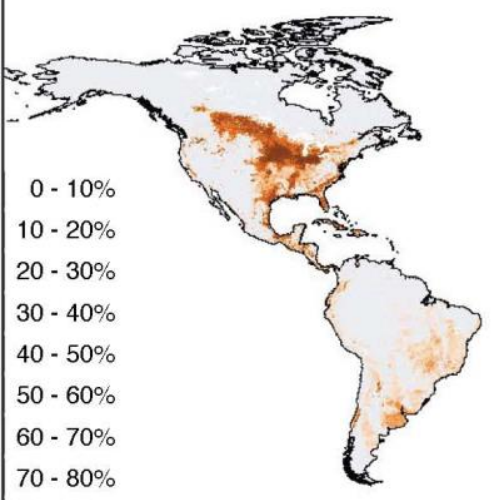

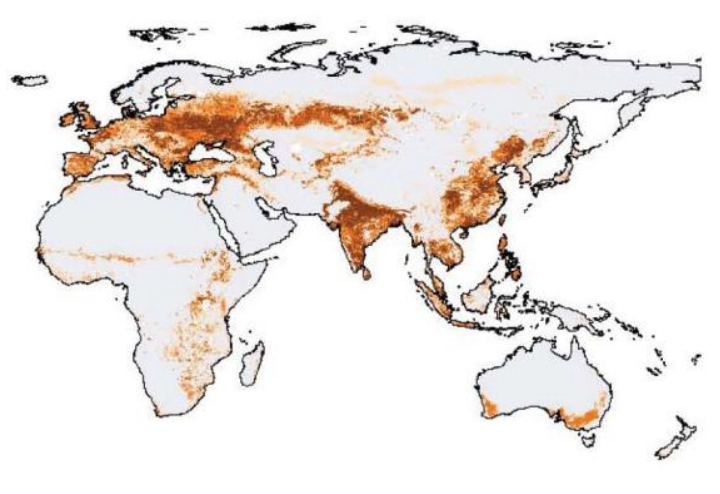

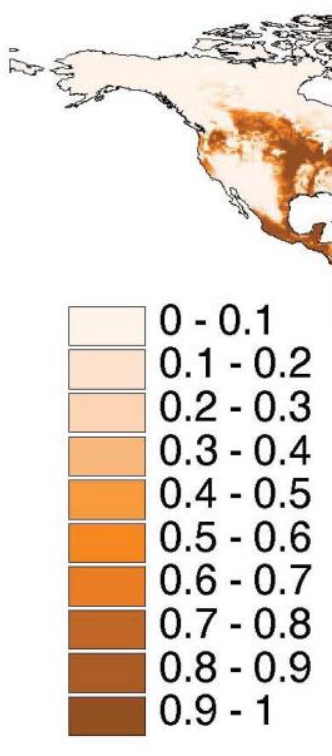

current

croplands

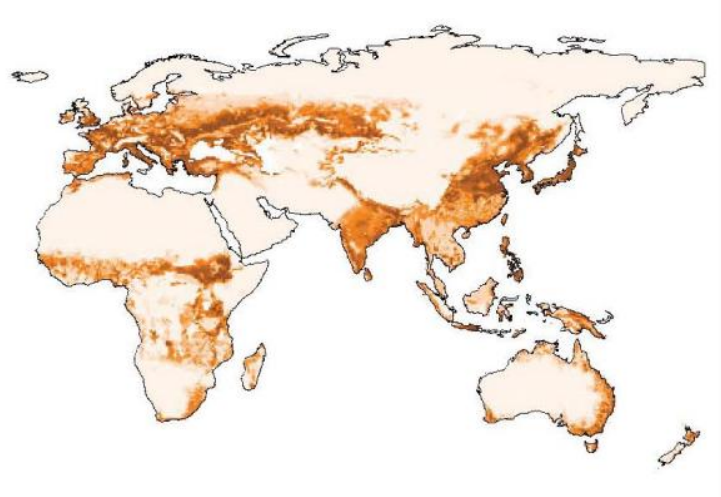

Note: additional area of 1 billion hecatres ( size of United States) of croplands is required to feed the additional population by 2050 .

\section{potential croplands}

\section{..only@Very High environmental/ecological costs....further high demand for land for alternatives uses (e.g., industry, urban, bio-fuel)} Source: Ramankutty et al., 2002; Foley, 2011 
Global Food Security in the 21 ${ }^{\text {st }}$ Century: Increasing Need of Cropland Areas and Agriculture Water for Food Security Croplands and Pasture lands already cover $1 / 3^{\text {rd }}$ of the Ice Free Planet

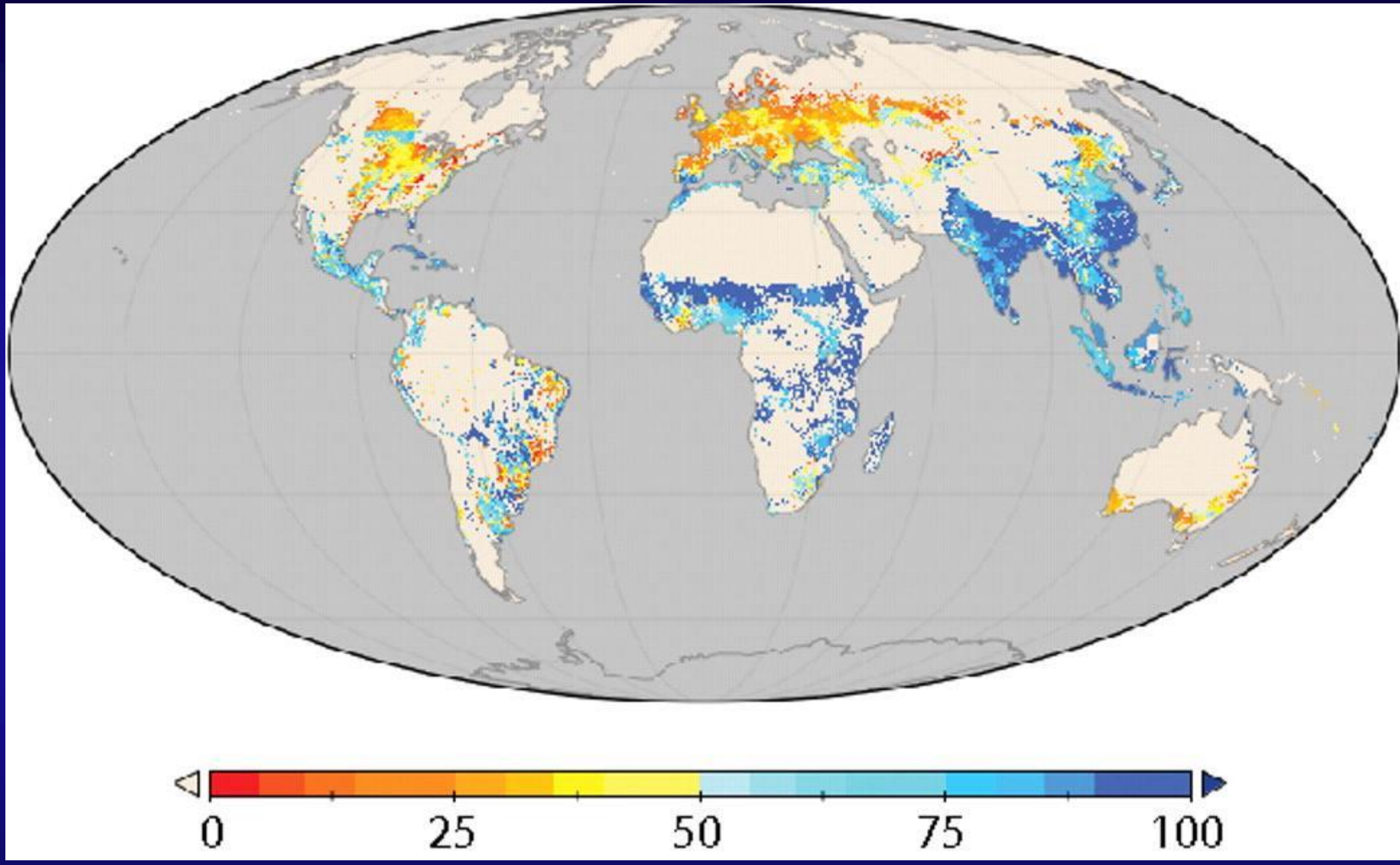

Source: Monfreda, C., N. Ramankutty, and J. A. Foley (In Press), Farming the Planet. 2: The Geographic Distribution of Crop Areas, Yields, Physiological Types, and NPP in the Year 2000, Global Biogeochemical 
Global Food Security in the $21^{\text {st }}$ Century: Increasing Need of Cropland Areas and Agriculture Water for Food Security Global Greenhouse Gas (GHG) Emissions will only Increase

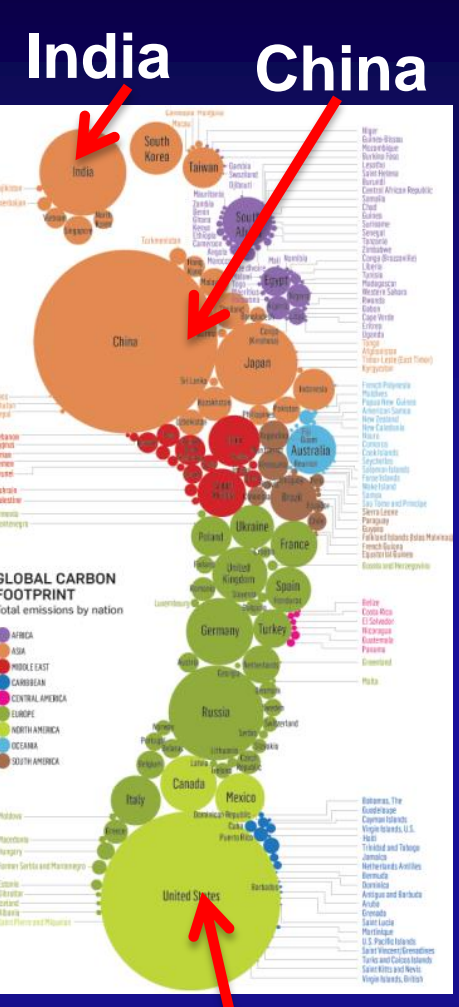

\section{USA}

China: $28 \%$ USA: $14 \%$ EU: $10 \%$ India: 7\%

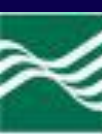
USGS science for a changing world U.S. Geological Survey U.S. Department of Interior
World GHG Emissions Flow Chart Sector

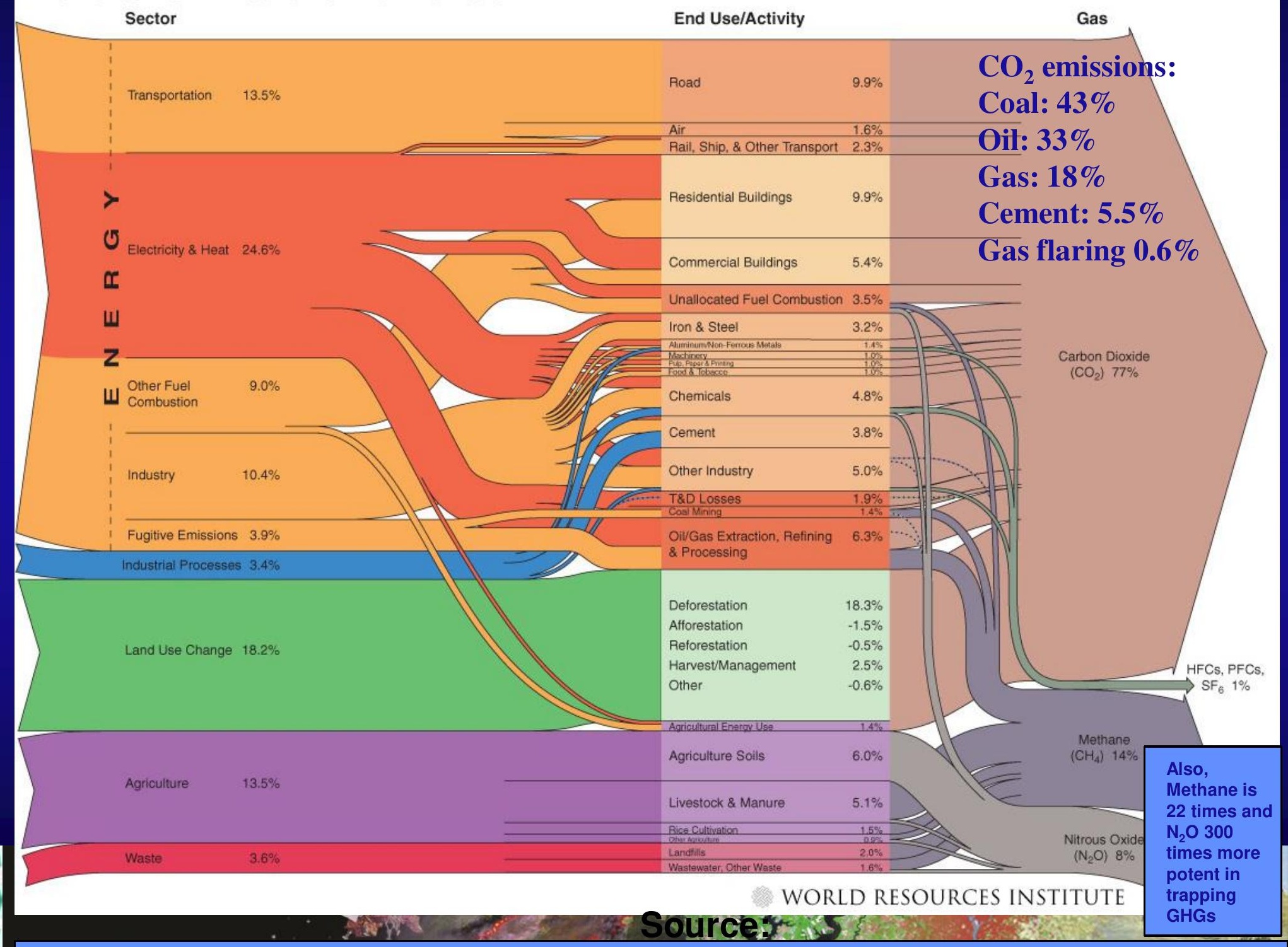

..economic growth must pay for environmental/ecological damages 
Global Food Security in the $21^{\text {st }}$ Century: Increasing Need of Cropland Areas and Agriculture Water for Food Security Global Greenhouse Gas (GHG) Emissions will only Increase

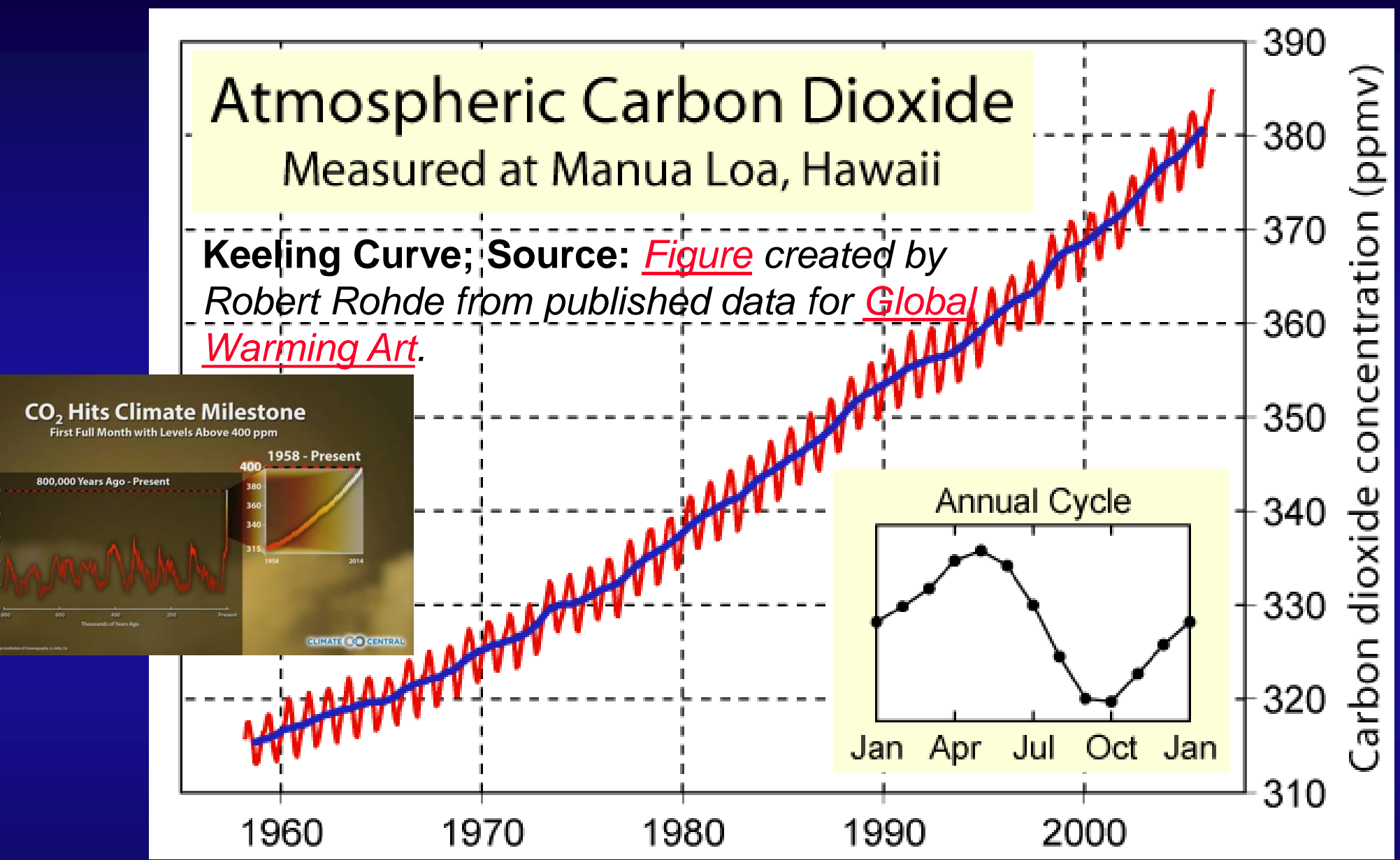

Agriculture contributes to $\sim 14 \%$ of 31.6 billion Metric Tons (Gt) of $\mathrm{CO}_{2}$ in 2011 . However, note the "breathing cycle" of the planet wherein summer months in Northern Hemisphere where plant activity is highest helps suck in the CO2 in atmosphere. 
Global Food Security in the 21 ${ }^{\text {st }}$ Century: Increasing Need of Cropland Areas and Agriculture Water for Food Security

\section{Environmental/Ecological Damage Can be Irreversible}
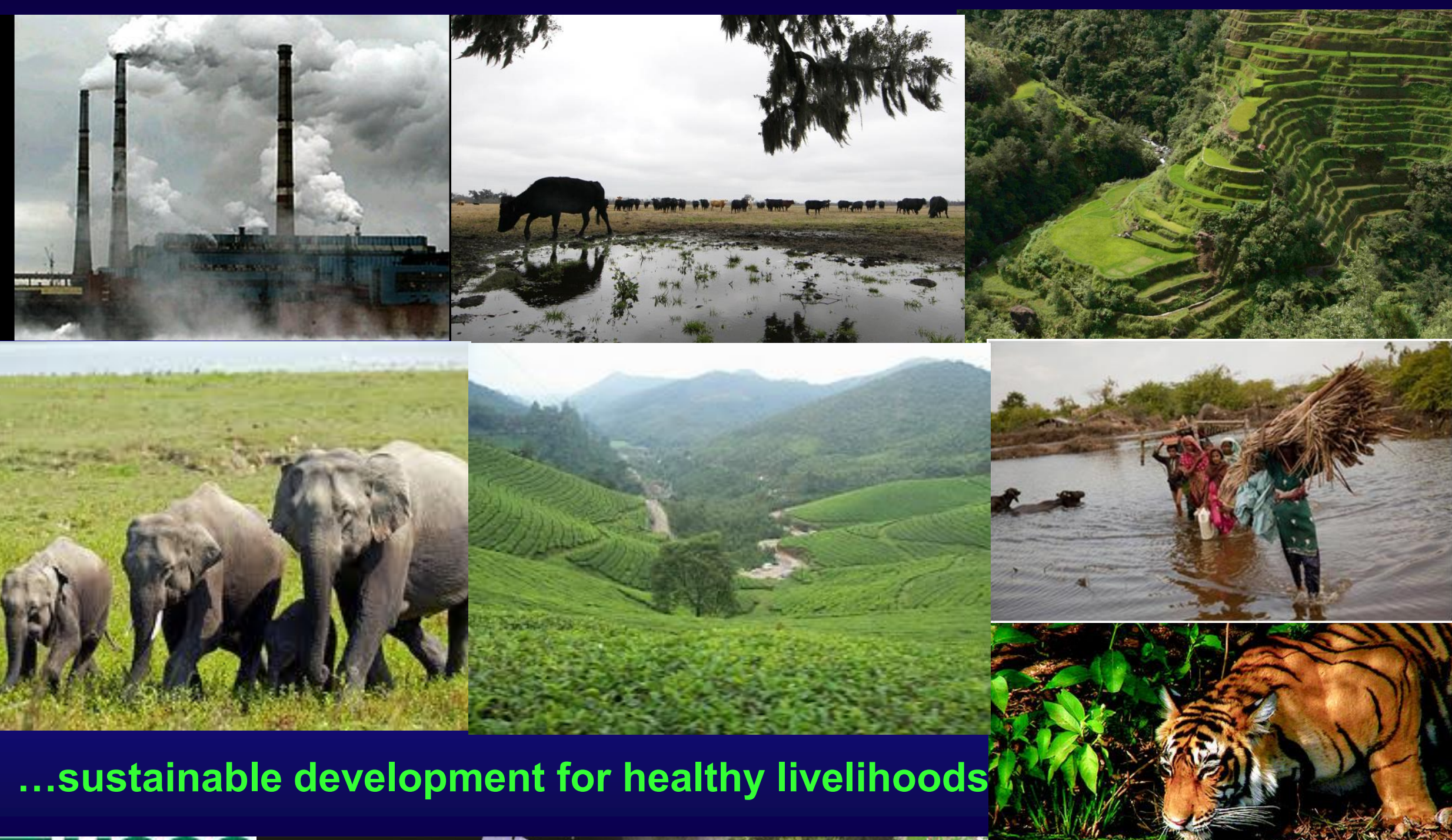

....sustainable development for healthy livelihoods 
Global Food Security in the $21^{\text {st }}$ Century: Increasing Need of Cropland Areas and Agriculture Water for Food Security

\section{Addressing the Global Food Security Challenge}

Next 50 years World needs to meet the food demand of a population which will grow from 7 billion in year 2011 to 9 or 10 billion by 2050. There is a consensus view that:

1. Increasing cropland areas is NOT a solution;

2. Increasing water allocations (e.g., more irrigation) is NOT a solution.

So a New paradicm to increase food

production that is ecologically, environmentally friendly with: (a) less croplands, and (b) less water allocations for croplands 


\section{Global Food Security Setting a Stage for A New Paradigm}

₹USGS

4

U.S. Department of Interior

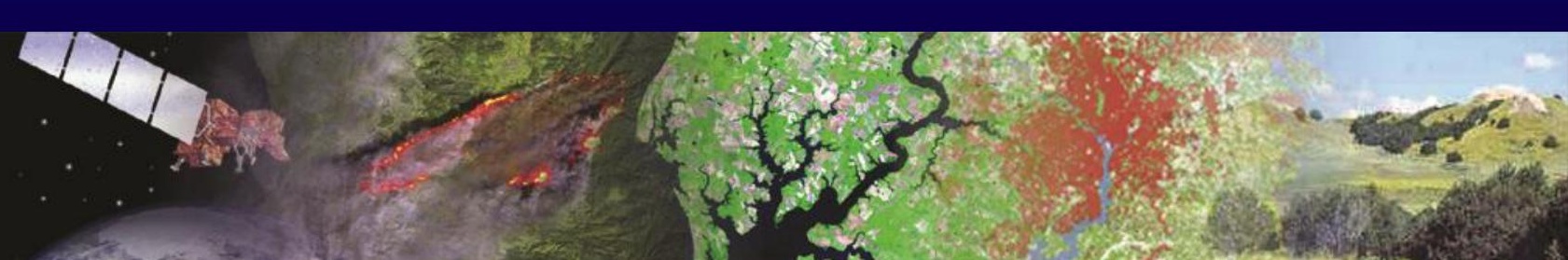


Global Food Security in the 21 $1^{\text {st }}$ Century: Increasing Need of Cropland Areas and Agriculture Water for Food Security

\section{Addressing the Global Food Security Challenge}

A critical and urgent question facing humanity in the twentyfirst century is, how can we continue to feed the World's ballooning populations in the twenty-first century:

1. Without increasing cropland areas;

2. Without increasing allocations for cropland water use;

Indeed, an even better question to ask is how can we continue to feed the World's ballooning populations in the twenty-first century by

Reducing the existing cropland areas for food production? (e.g., taken away for bio-fuels, urbanization), andlor

2. Reducing the existing water allocations for food production? (e.g., water needed to produce unit of grain in increasing as a result of increasing temperature in a changing climate)
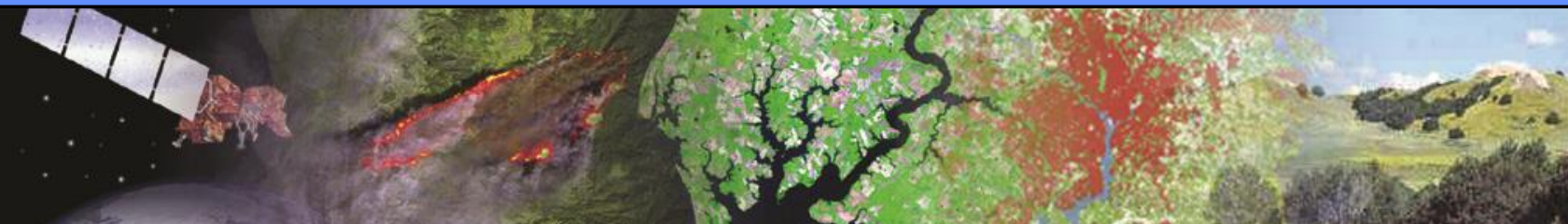


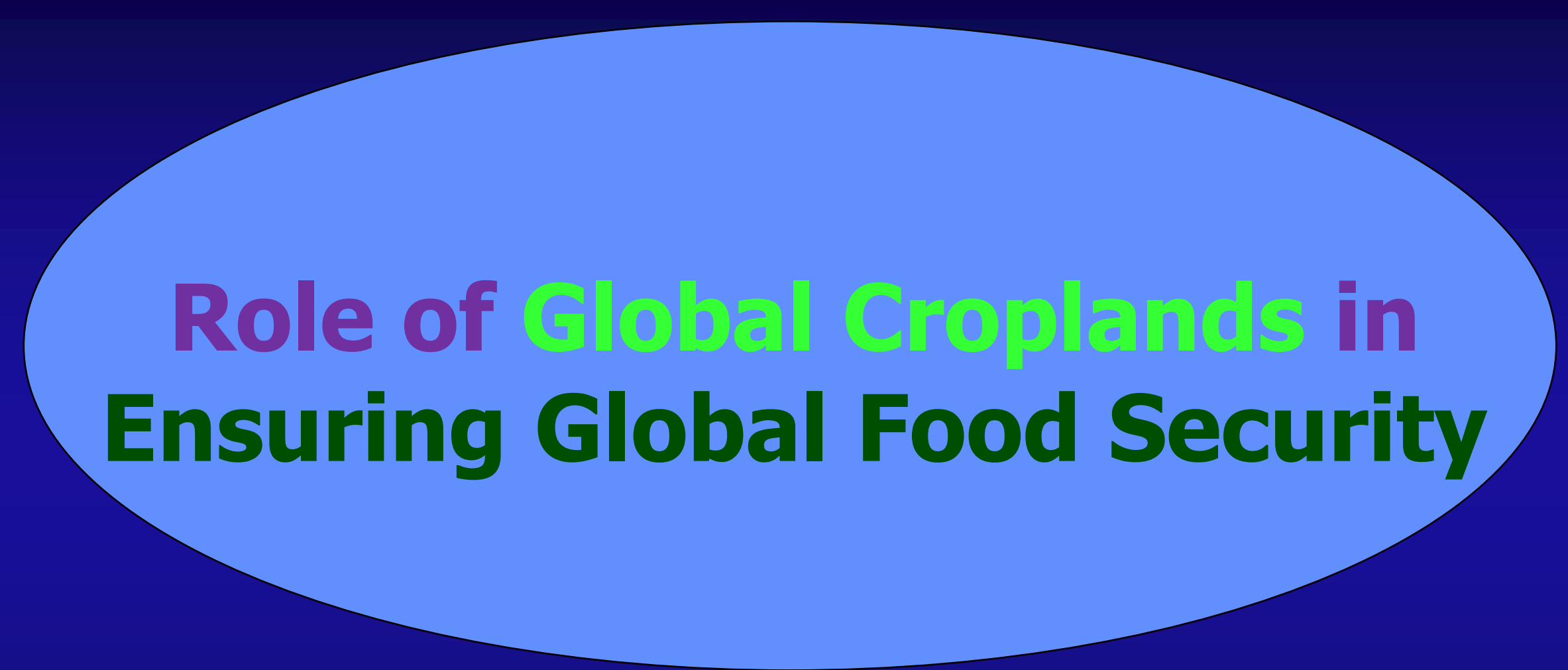

science for a changing world

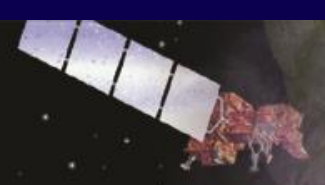

U.S. Geological Survey

U.S. Department of Interior 


\section{History and Current State of Global Croplands}

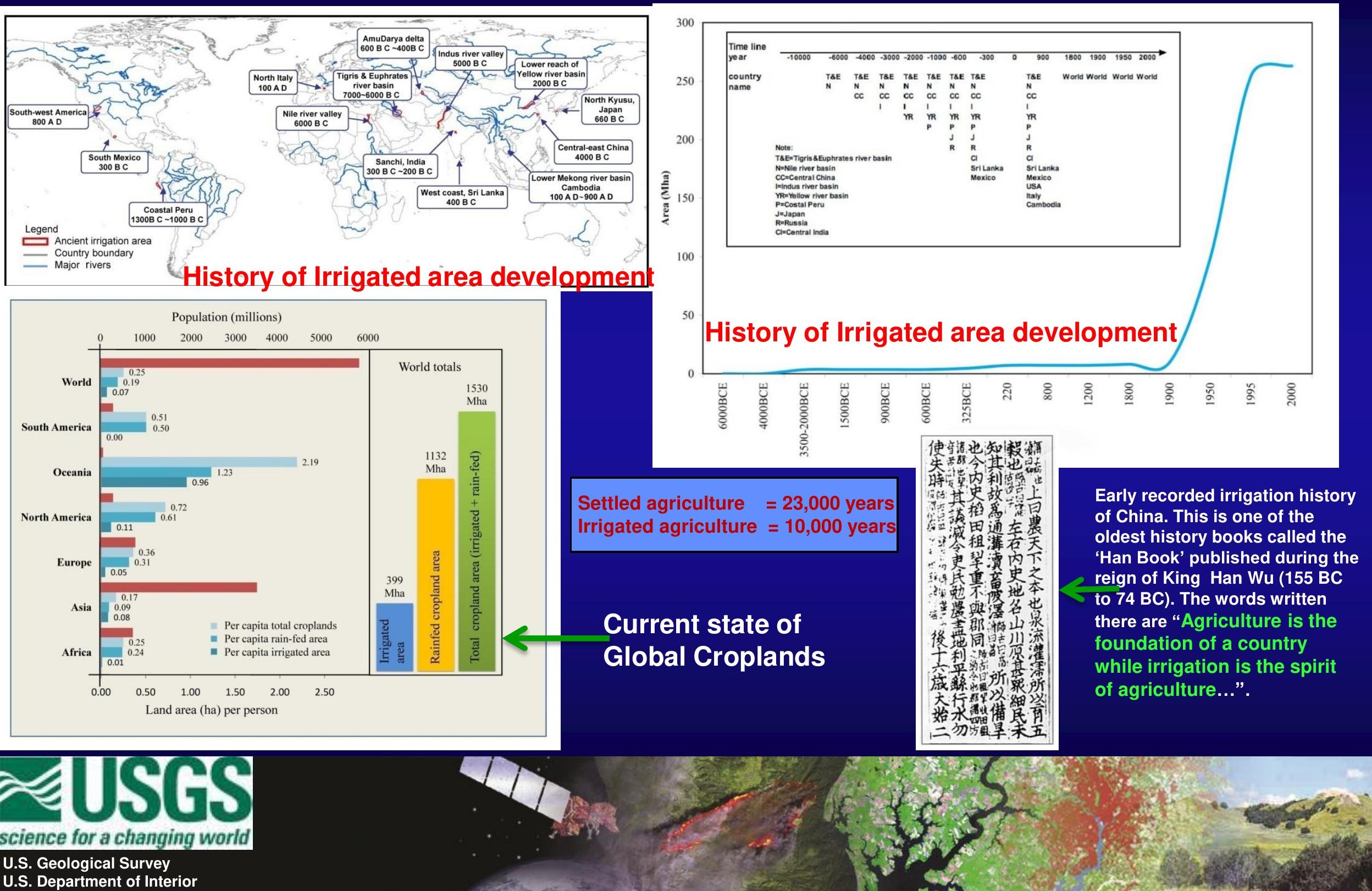


Global Food Security in the 21 $1^{\text {st }}$ Century: Increasing Need of Cropland Areas and Agriculture Water for Food Security

\section{History and Current State of Global Croplands}

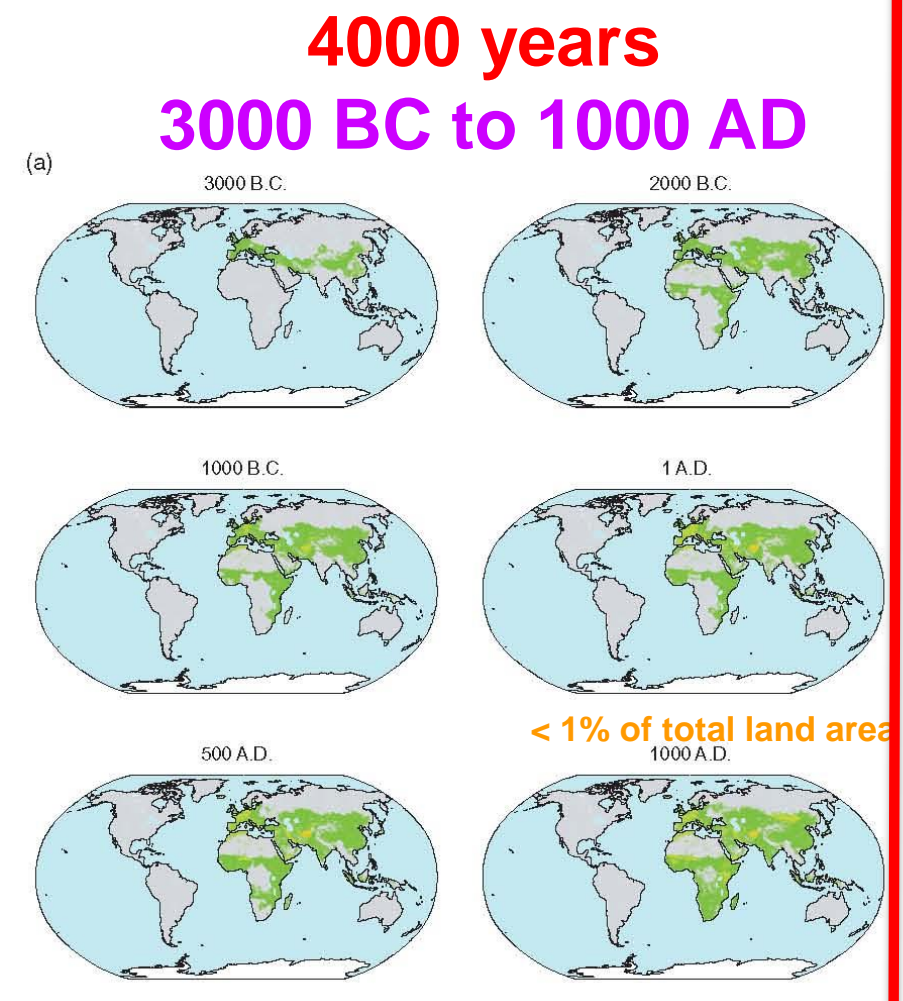

$\mathrm{km}^{2} /$ grid cell

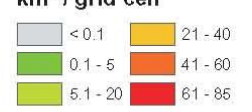

Figure 2 Historical pasture area (a) $3000 \mathrm{BC}$ to AD 1000 and (b) AD 1500-2000.

\author{
Past 500 years \\ 1500 AD to 2000 AD
}

(b)
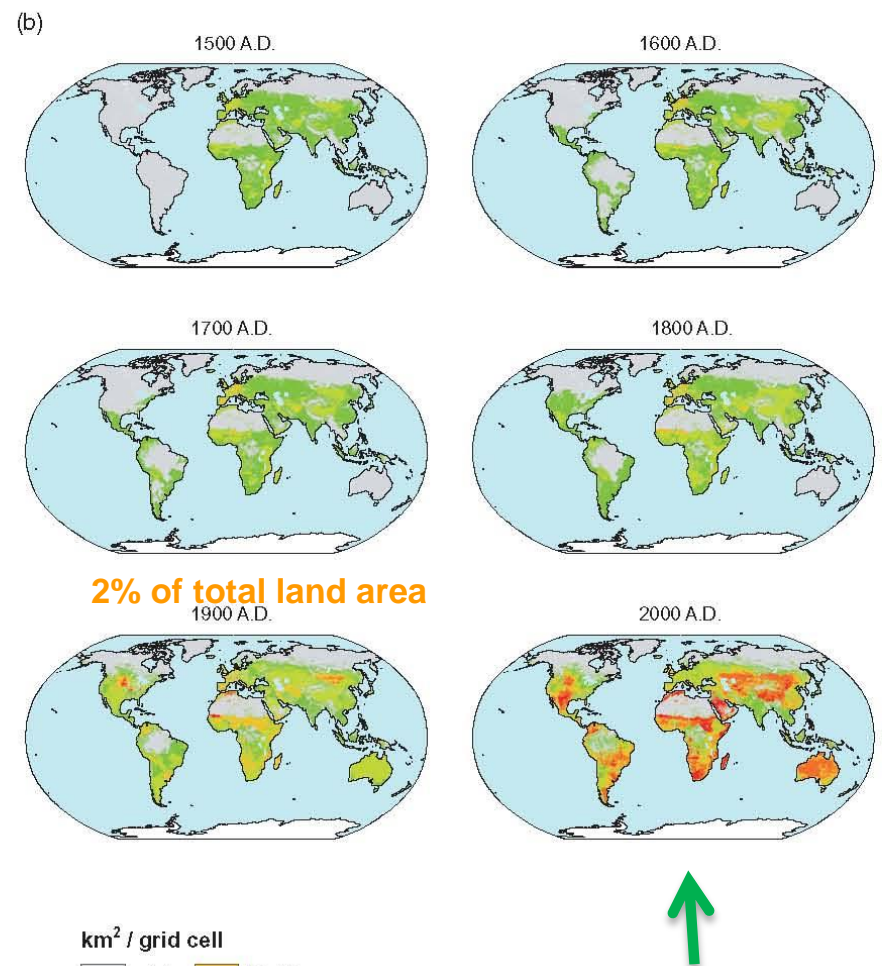

$\mathrm{km}^{2} /$ grid cell

$\square<0.1$
$\square$
$0.1-5$
$\square .1-20$
$\square$ $\begin{aligned} & 21-40 \\ & 41-60 \\ & 61-85\end{aligned}$ $\sim 1.5$ to 1.7 billion ha. ( 10.3 to $12 \%$ of total land area)

\section{Goldewijk et al., 2011 011}


Global Food Security-support Data @ 30 m (GFSAD30) Project GCE $1 \mathrm{~km}$ Multi-study Crop Mask (aka GCE V1.0) http://geography.wr.usgs.gov/science/croplands/index.html

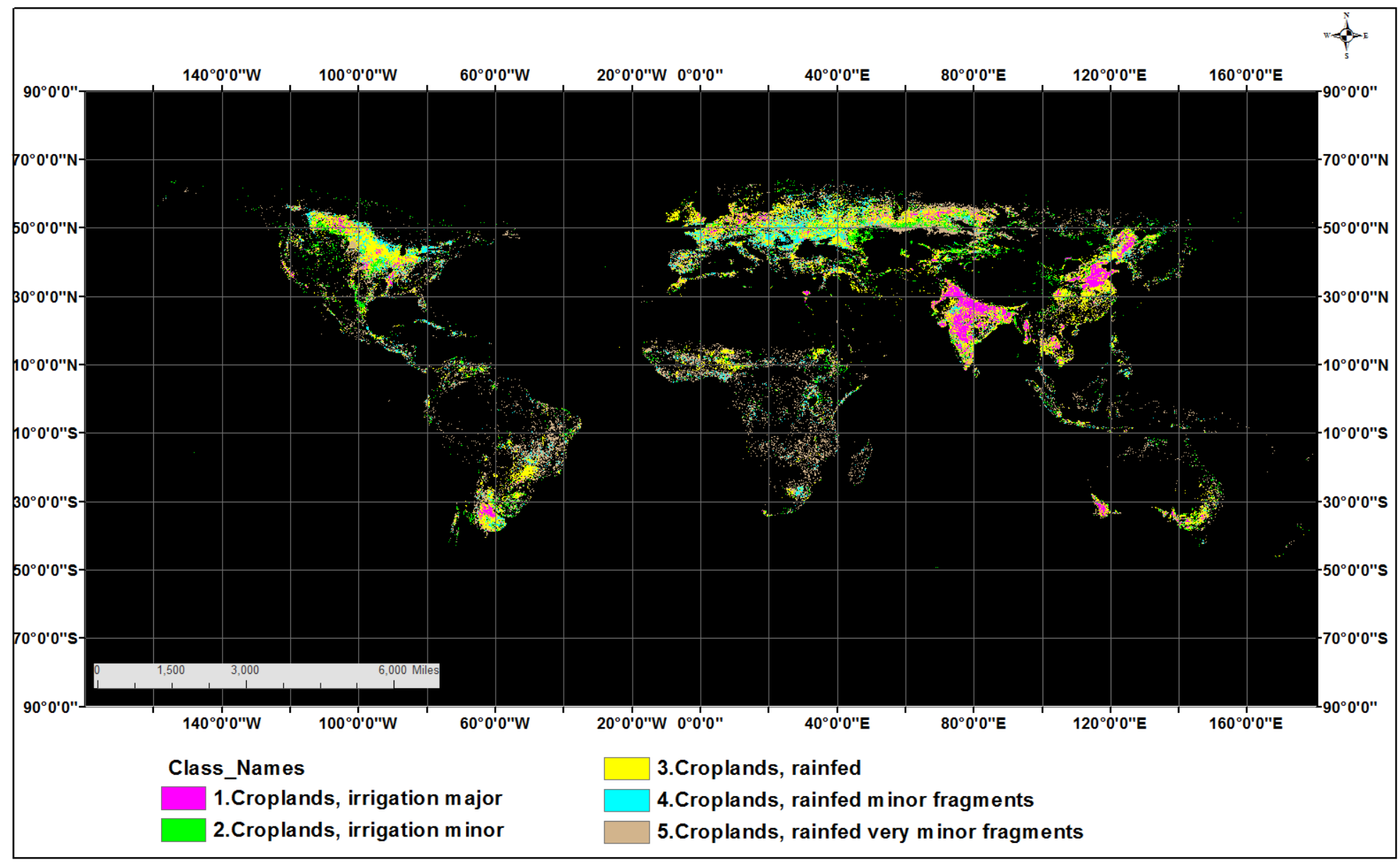

$\sim 2.3$ billion hectares full pixel area (FPAs) with $34 \%$ irrigated and $66 \%$ rainfed.

Teluguntla, P., Thenkabail, P.S., Xiong, J., Gumma, M.K., Giri, C., Milesi, C., Ozdogan, M., Congalton, R., Tilton, J., Sankey, T.R., Massey, R., Phalke, A., and Yadav, K. 2015. Global Cropland Area Database (GCAD) derived from Remote Sensing in Support of Food Security in the Twenty-first Century: Current Achievements and Future Possibilities. Chapter 7, Vol. II. Land Resources: Monitoring, Modelling, and Mapping, Remote Sensing Handbook edited by Prasad S. Thenkabail. Accepted. http://geography.wr.usgs.gov/science/croplands/pulbs2014.html 
Global Food Security in the $21^{\text {st }}$ Century: Increasing Need of Cropland Areas and Agriculture Water for Food Security

Global Agricultural Cropland Monitoring System http://geography.wr.usgs.gov/science/croplands/index.html

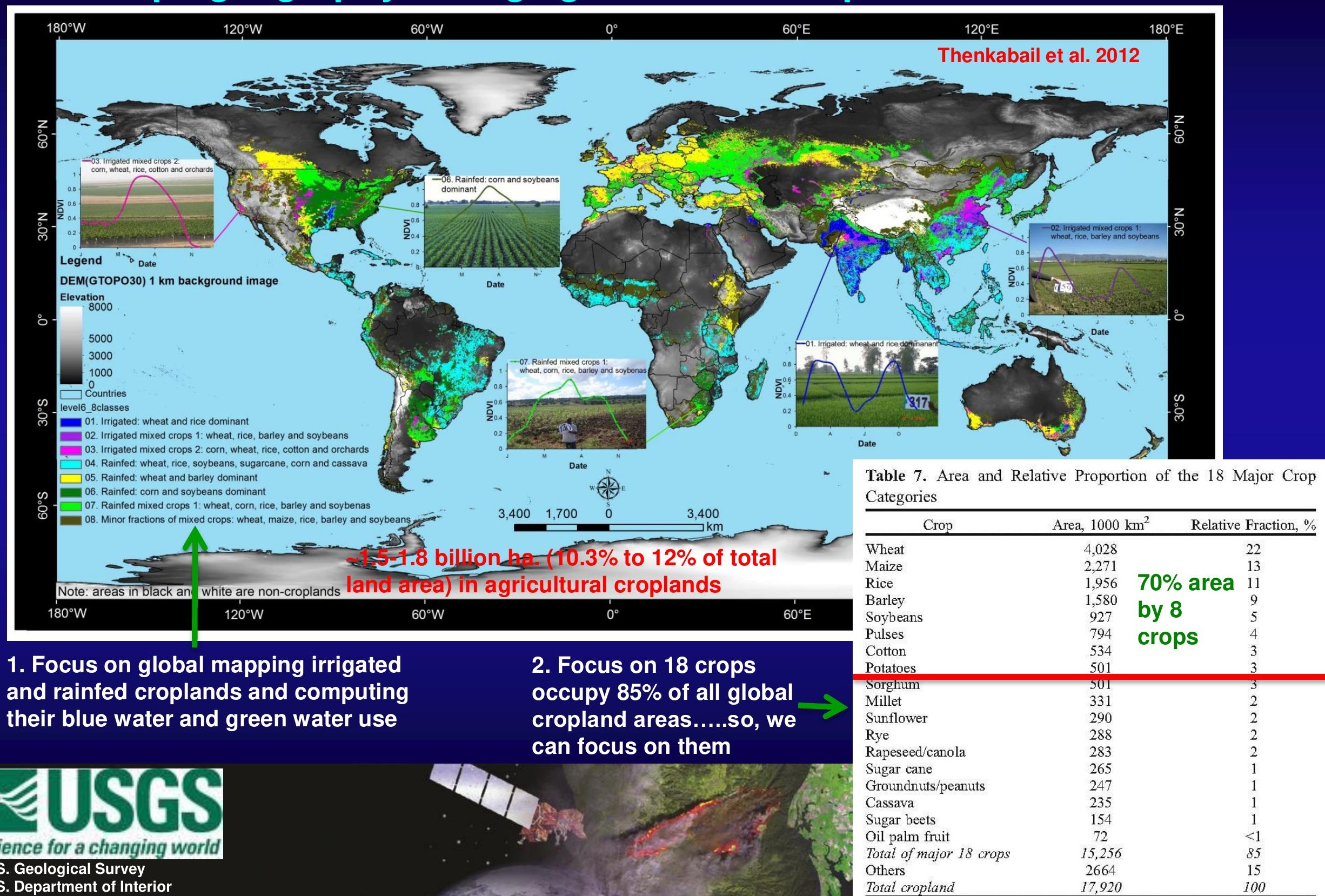




\section{Earth Observation Based Global Agricultural Cropland Monitoring System}

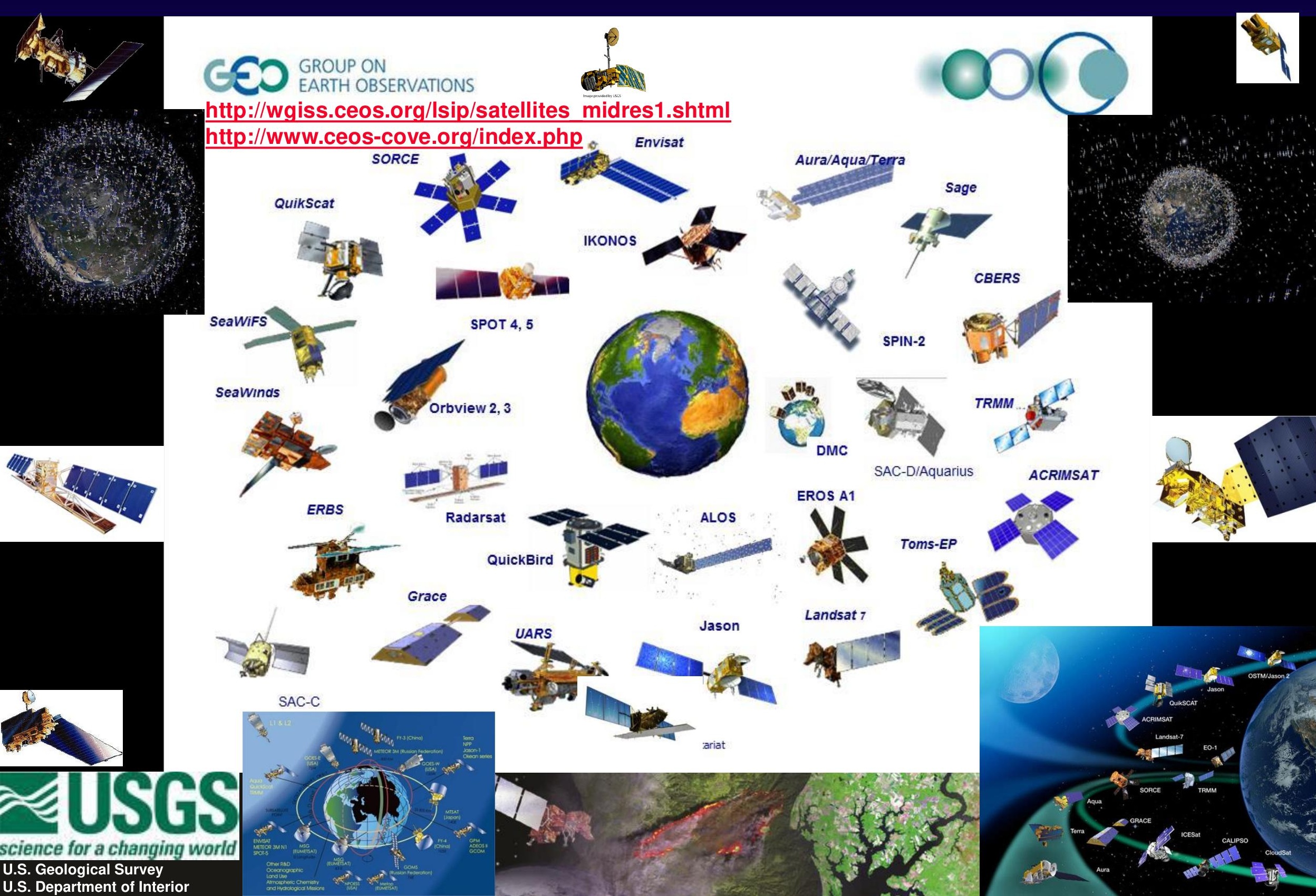




\section{Global Croplands (irrigated + rainfed + permanent crops)}

Source: AVHRR, SPOT VGT, Secondary (e.g., precipitation, elevation), groundtruth (Primarily remote sensing) Earth Observation (EO) Data for Cropland Monitoring

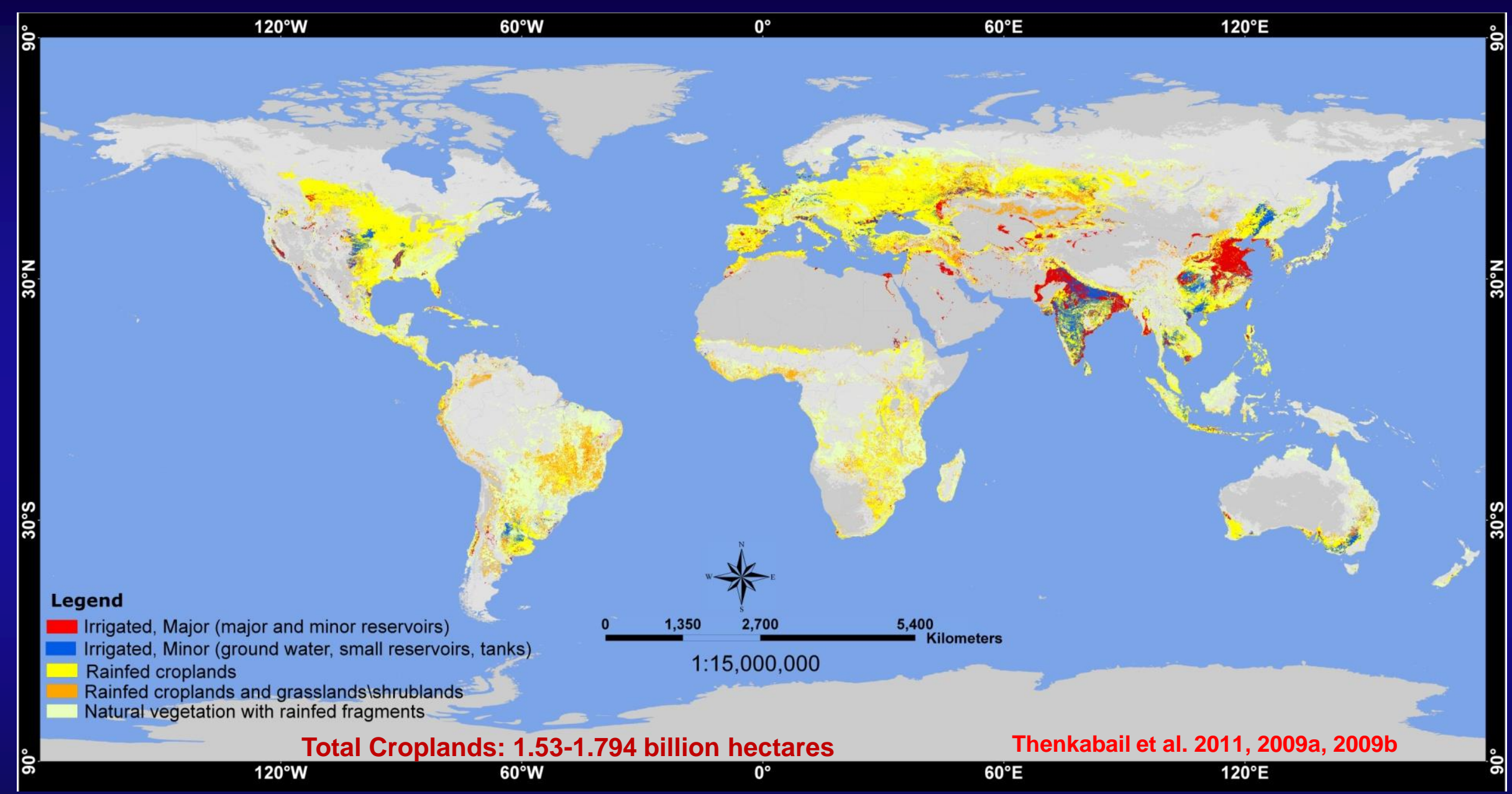

Note: total land area $=14.894$ billion hectares $\left(148,940,000 \mathrm{~km}^{2}\right)$. Total cropland area is $10.3-12 \%$ in year 2000 
Global Food Security in the 21 $1^{\text {st }}$ Century: Increasing Need of Cropland Areas and Agriculture Water for Food Security Global Agricultural Cropland Monitoring System using EO Data

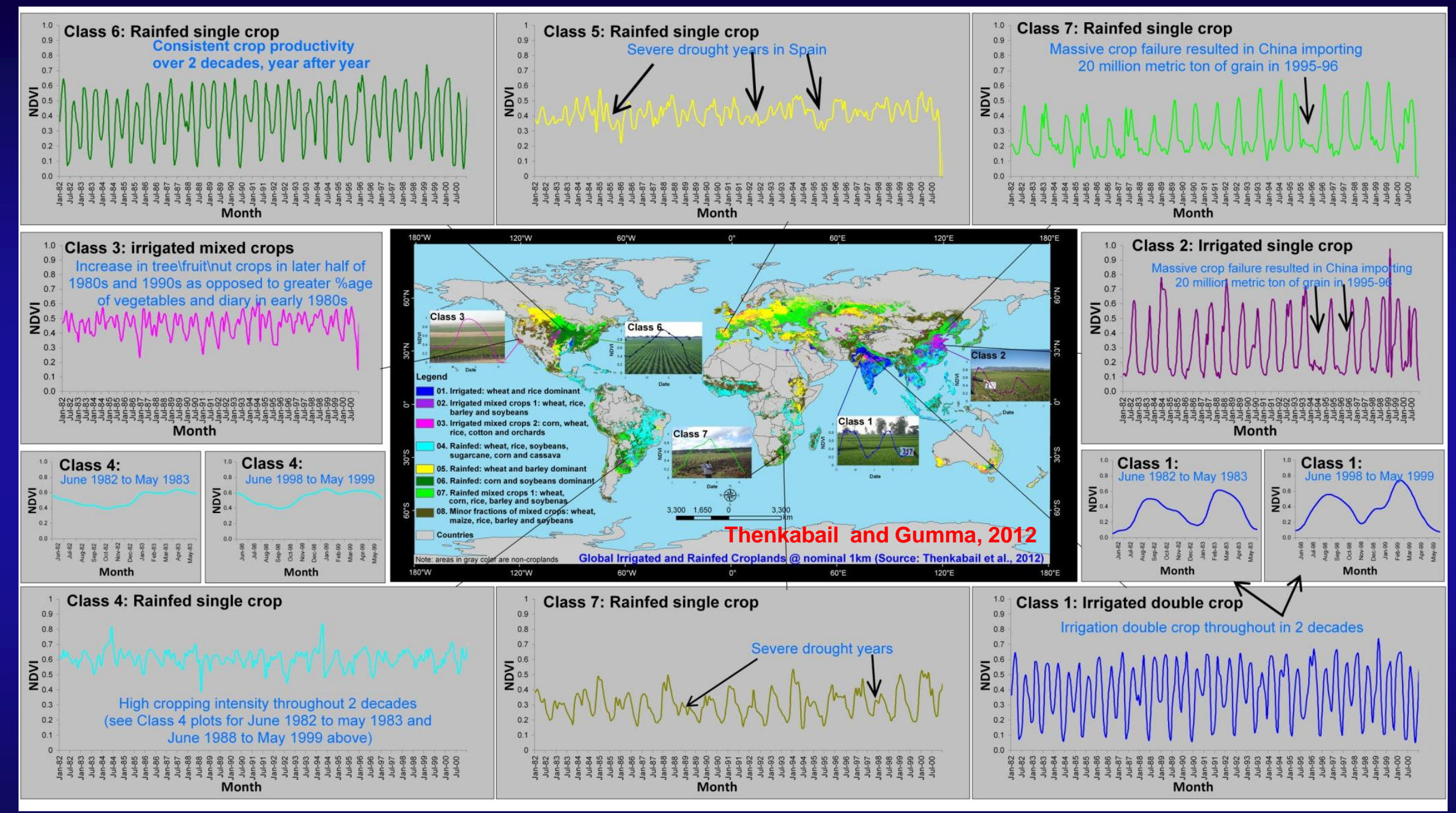

\section{Month by Month NDVI dynamics of global croplands. Years 1982-2000}
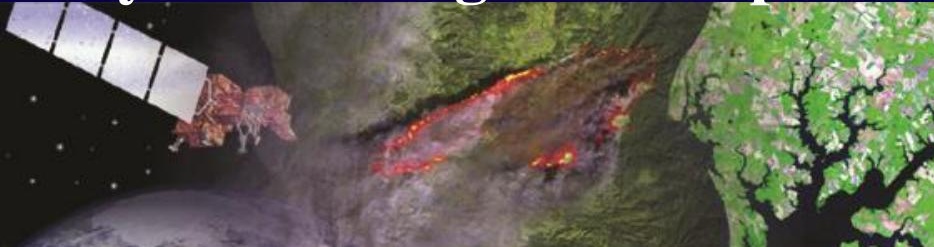


\section{Opportunities and Challenges for}

Advancing Accurate Cropland Maps and Statistics: Need for Time-series data EO Data Looking at Crop Dynamics: Month of April from 1981-2001
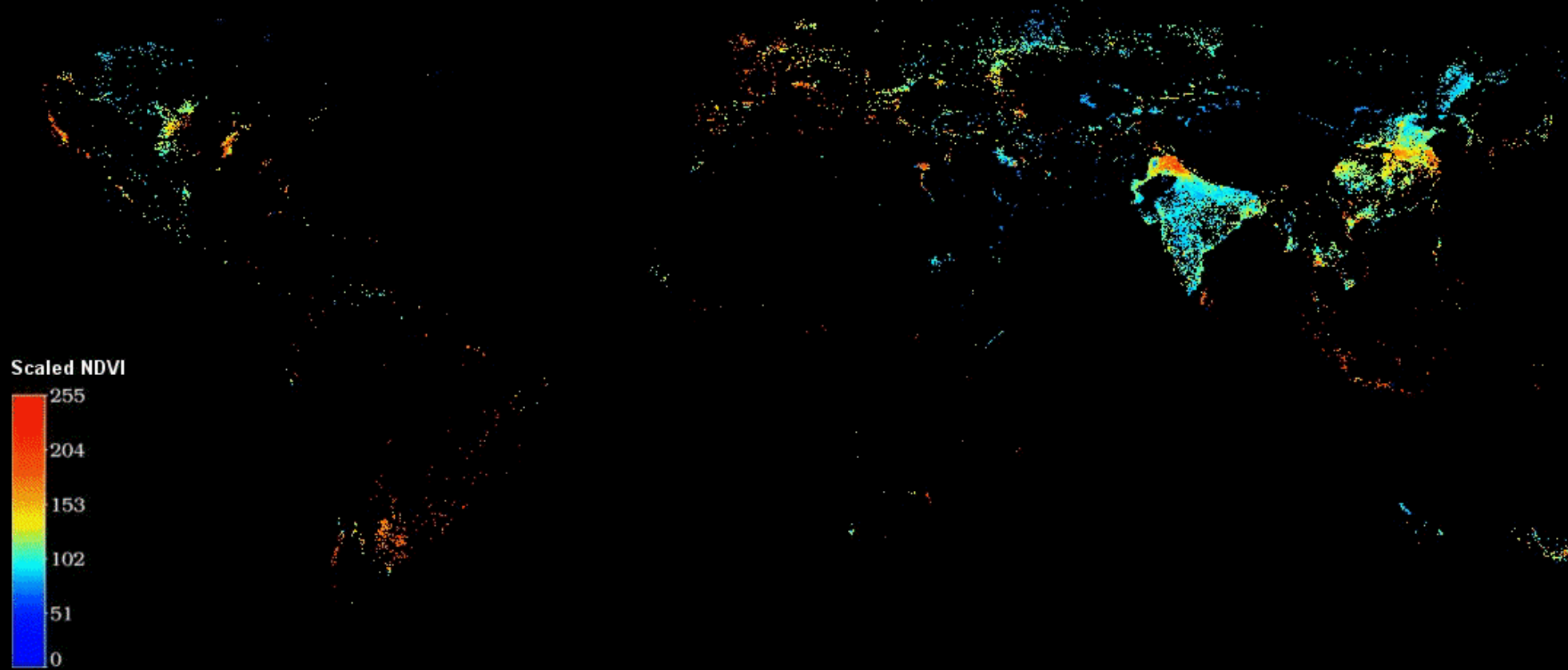

April 1982

....current GIMMS (Global Inventory Modeling and Mapping Studies) bi-monthly global data: 1982-2011, followed by MODIS (Moderate Resolution Imaging Spectroradiometer) terralaqua from 2000-present, then onto NPP (NPOESS Preparatory Project) 2011-, and NPOESS (National Polar-orbiting Operational Environmental Satellite System) upcoming.

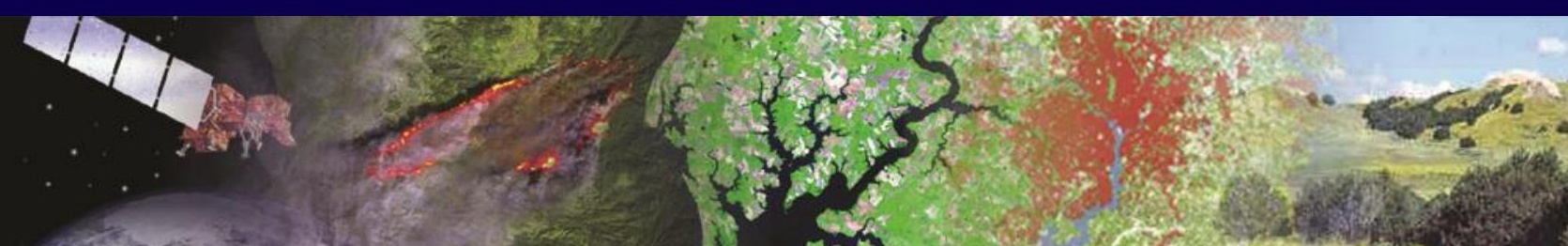


Multi-sensor imagery from NOAA AVHRR+SPOT VGT + secondary data (e.g., precip., temp, elev.) + ground data

\section{Annualized Irrigated} Areas $(\mathrm{AIAs})=152$ Mha
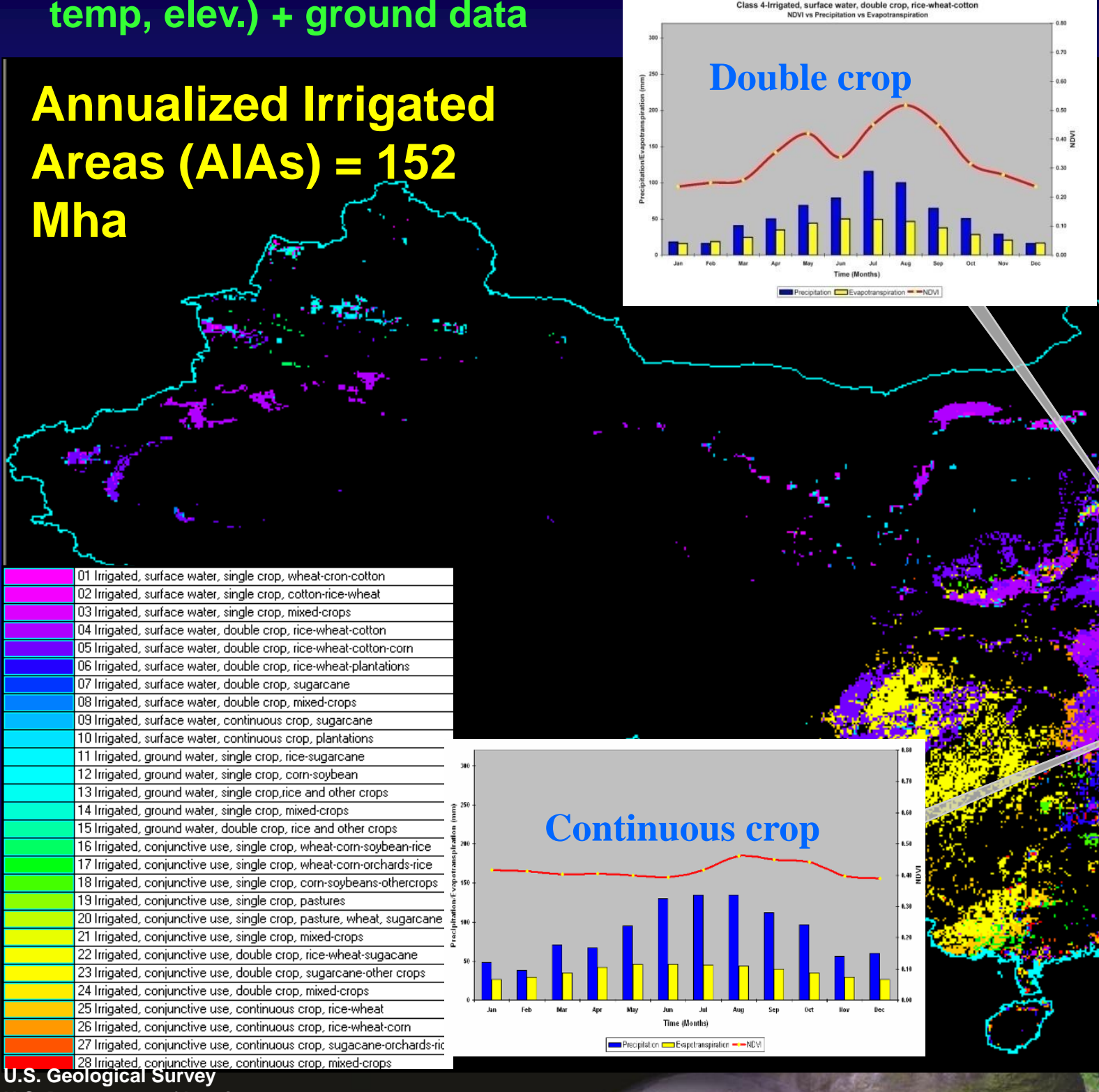

U.S. Department of Interior
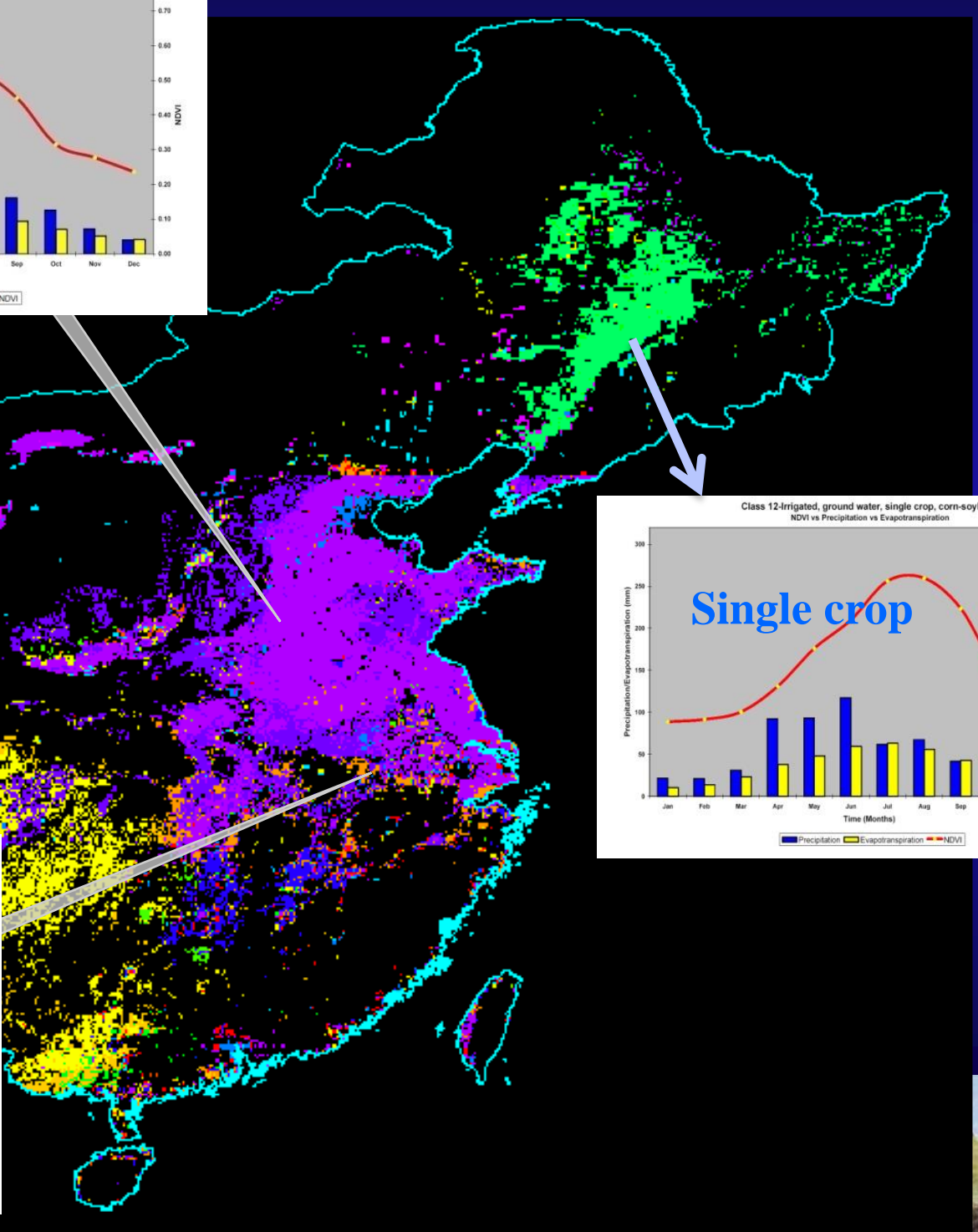
Global Food Security-support Analysis Data @ 30 m (GFSAD30) Project

\section{Overarching Goal}

Monitoring global croplands (GCs) is imperative for ensuring sustainable water and food security to the people of the world in the Twenty-first Century. However, the currently available cropland products suffer from major limitations such as:

(1) Absence of precise spatial location of the cropped areas; (b) Coarse resolution nature of the map products with significant uncertainties in areas, locations, and detail; (b) Uncertainties in differentiating irrigated areas from rainfed areas; (c) Absence of crop types and cropping intensities; and (e) Absence of a dedicated webldata portal for the dissemination of cropland products.

\section{The overarching goal of this project is to produce} consistent and unbiased estimates of global agricultural cropland areas, crop types, crop watering method, and cropping intensities using Multi-sensor, Multi-date Remote Sensing and mature cropland mapping algorithms (CMAS).

http://geography.wr.usgs.gov/science/croplands/index.html 
GFSAD30: NASA MEaSUREs Project on Global Food Security Key Products for the Entire World @ 30m (Landsat + MODIS + secondary) http://geography.wr.usgs.gov/science/croplands/index.html

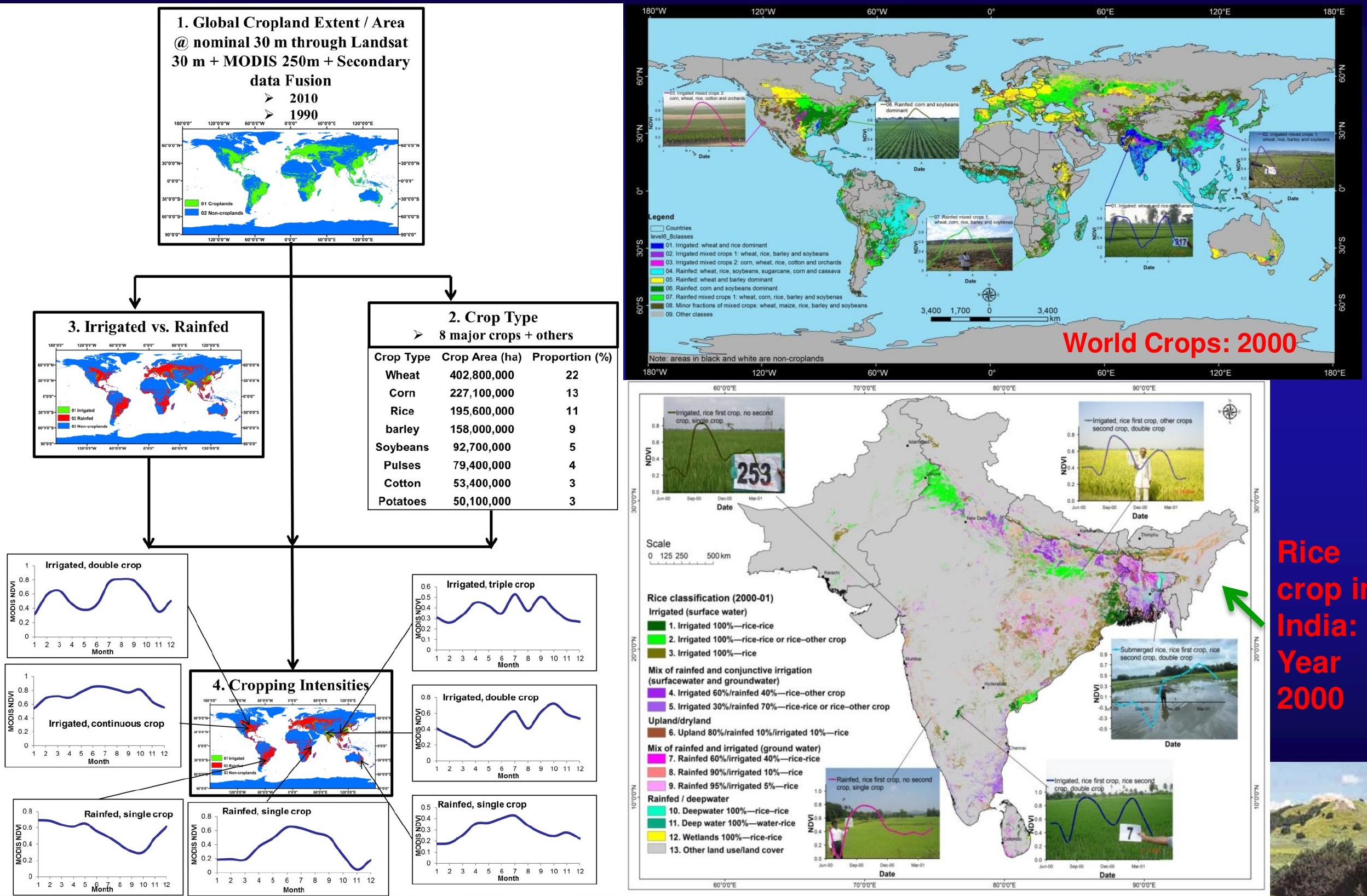




\section{Global Agricultural Monitoring System}

Crop Type Distribution: 4 Major crops that occupy $~ 55 \%$ of Total global Cropland Area (1.5 billion ha.)
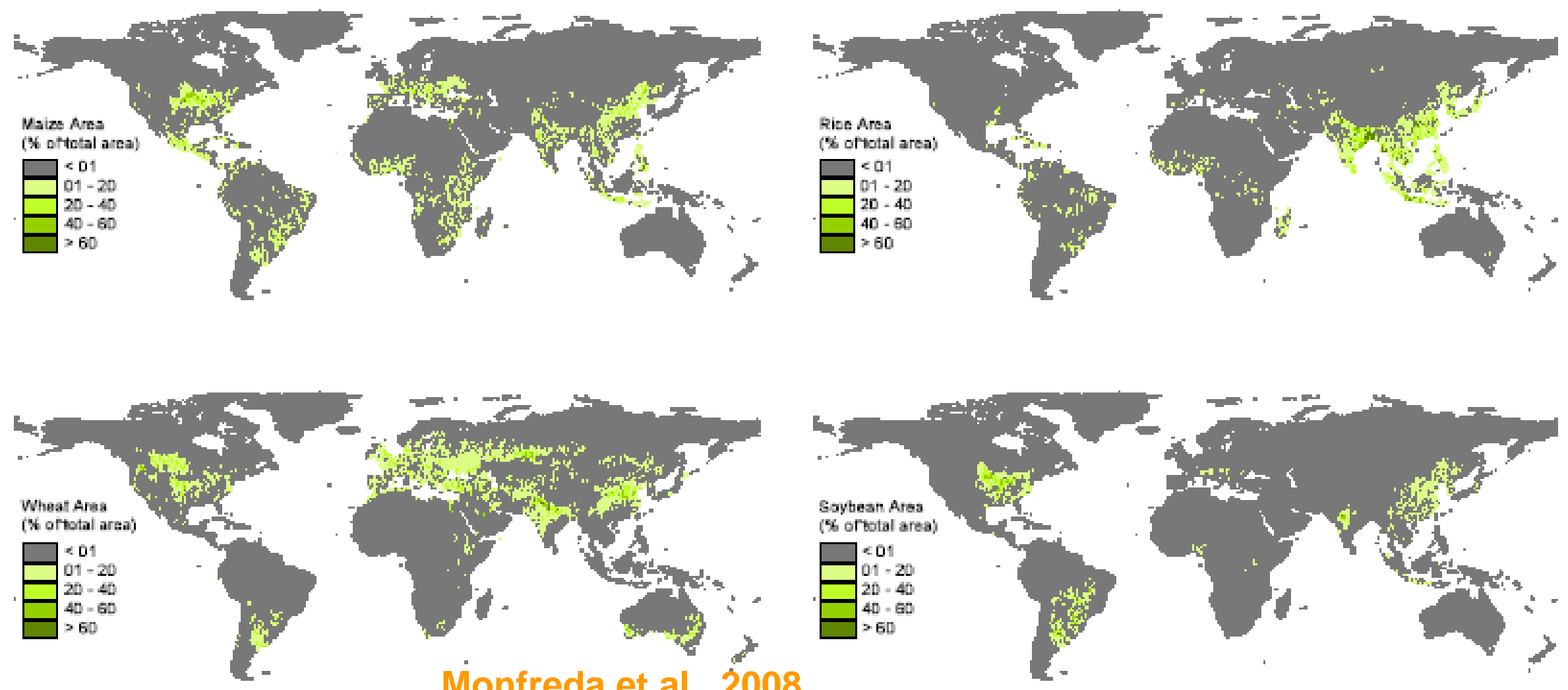

Mionfreda et al., 2008

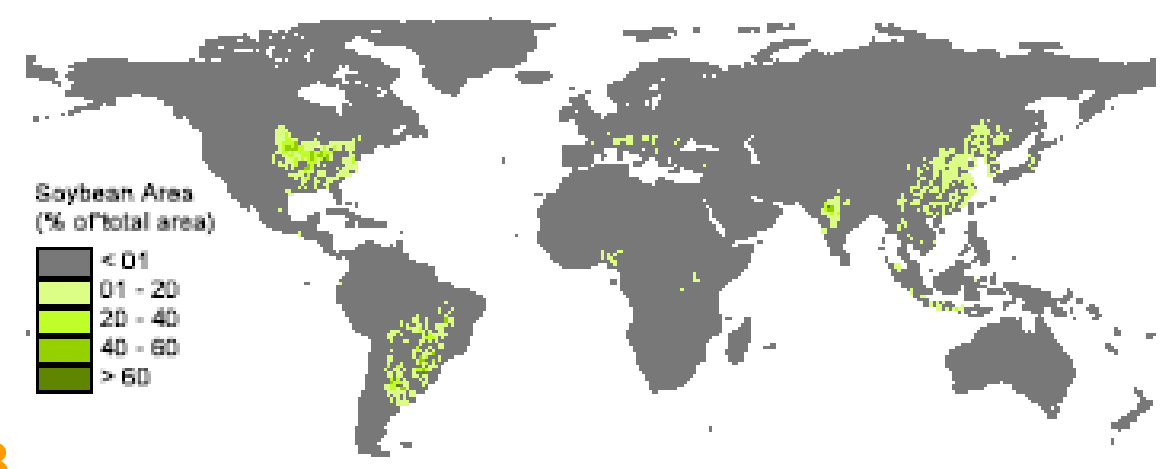

....focus on these crops to increase crop productivity ("crop per unit of land") and water productivity ("crop per unit of water")
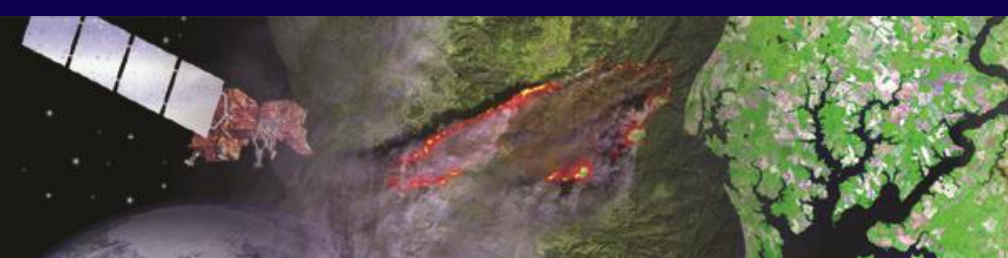


\section{Global Food Security-support Analysis Data @ 30 m (GFSAD30) Project Cropland Products @ Different Resolutions}

1A. GCE 1km Crop Dominance (aka GCE V0.0)

- Cropland extent and areas;

- Cropland watering method: irrigation versus rainfed To a lesser extent

- Crop dominance (not type)

1B. GCE 1 km Multi-study Crop Mask (aka GCE V1.0)

- Cropland extent and areas;

- Cropland watering method: irrigation versus rainfed

2. GCE $250 \mathrm{~m}$ Crop Dominance (aka GCE V2.0)

- Cropland extent and areas;

- Cropland watering method: irrigation versus rainfed;

- Cropping intensity;

To a lesser extent

$1 \mathrm{~km}$

- Crop type andlor dominance

3. GCE 30m Crop Dominance (aka GCE V3.0)

- Cropland extent and areas;

- Cropland watering method: irrigation versus rainfed;

- Cropping intensity;

- Crop type andlor dominance

http://geography.wr.usgs.gov/science/croplands/index.html

\section{$250 \mathrm{~m}$}

\section{$30 \mathrm{~m}$}




\section{Opportunities and Challenges for}

Advancing Accurate Cropland Maps and Statistics: Need for Time-series Data
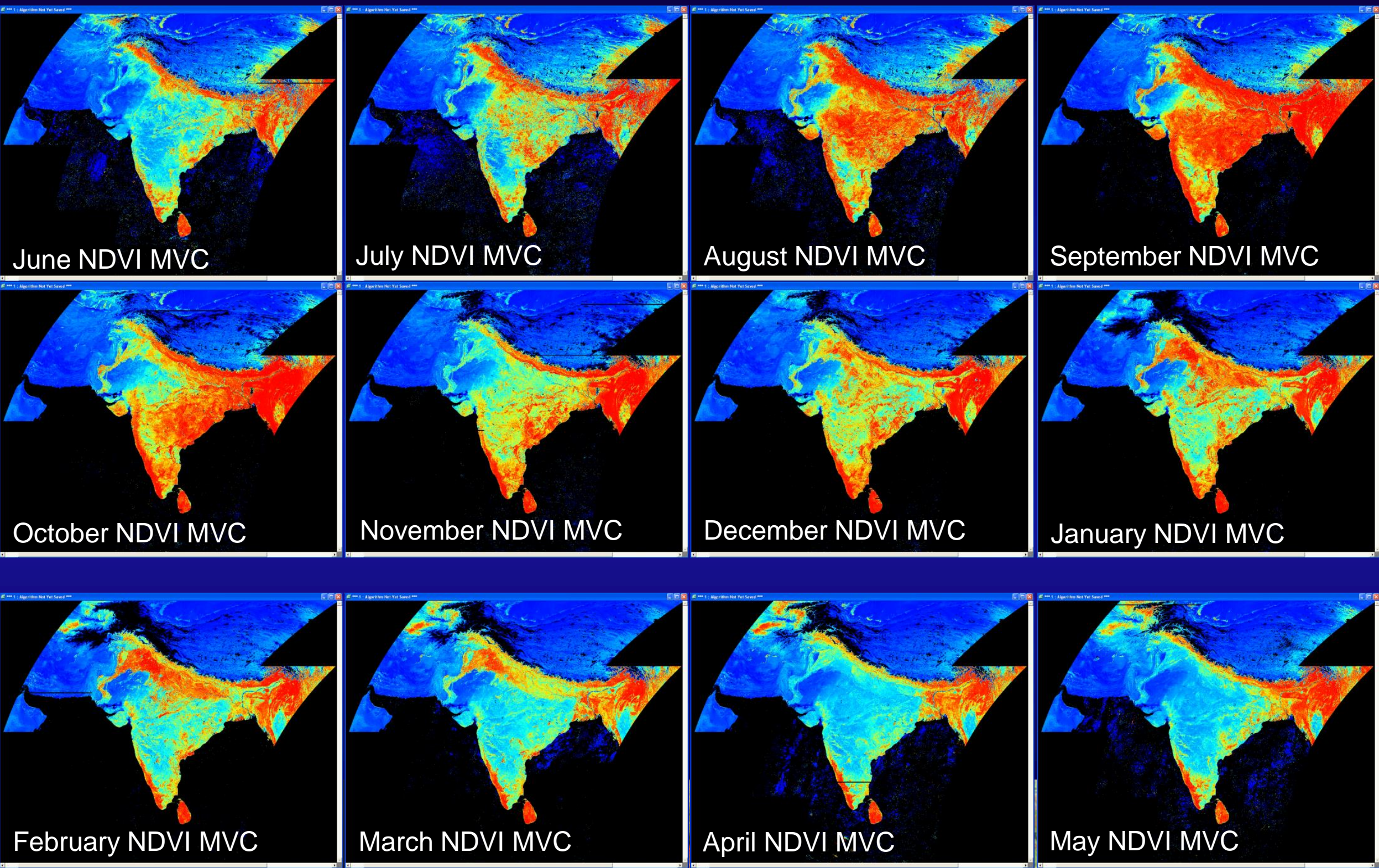
Global Food Security in the $21^{\text {st }}$ Century: Increasing Need of Cropland Areas and Agriculture Water for Food Security

\section{Mapping Crop Types of South Asia using EO Data} http://geography.wr.usgs.gov/science/croplands/index.html

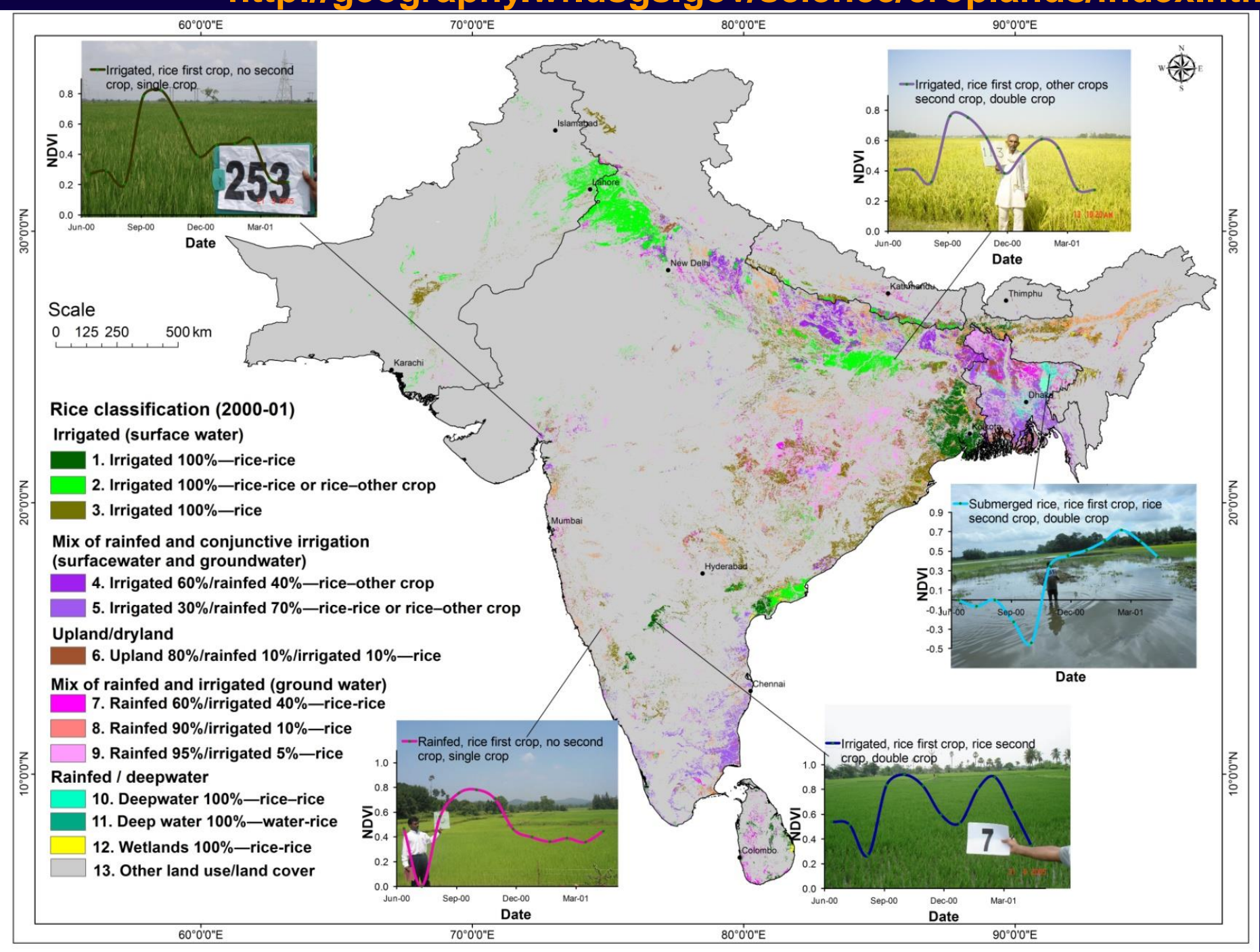

Rice map of South Asia for year 2010-11 using MODIS 250 m time-series Satellite Imagery
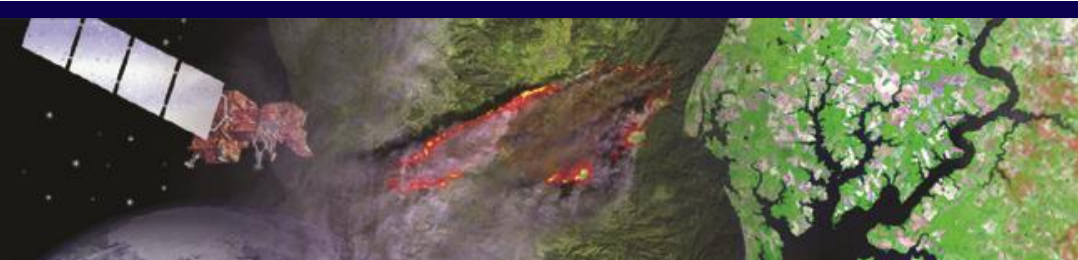
Global Food Security in the $21^{\text {st }}$ Century: Increasing Need of Cropland Areas and Agriculture Water for Food Security Global Agricultural Cropland Monitoring System using EO Data Future EO data (e.g., Hyperspectral) will allow us to Capture crop biophysical and biochemical properties with ever greater precision

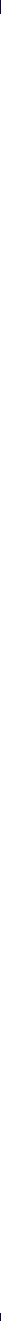




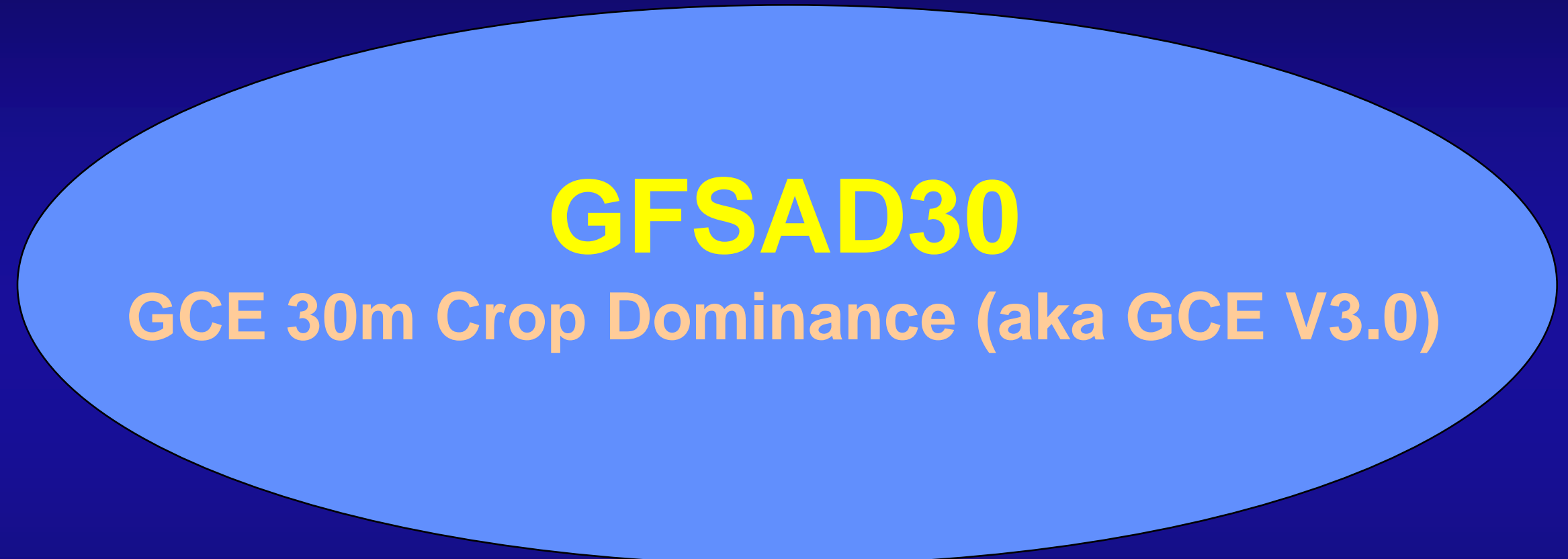

http://geography.wr.usgs.gov/science/croplands/index.html 


\section{GCE 30m Crop Dominance (aka GCE V3.0) @ nominal 30m Study Areas Splitting the World with sub-Teams}

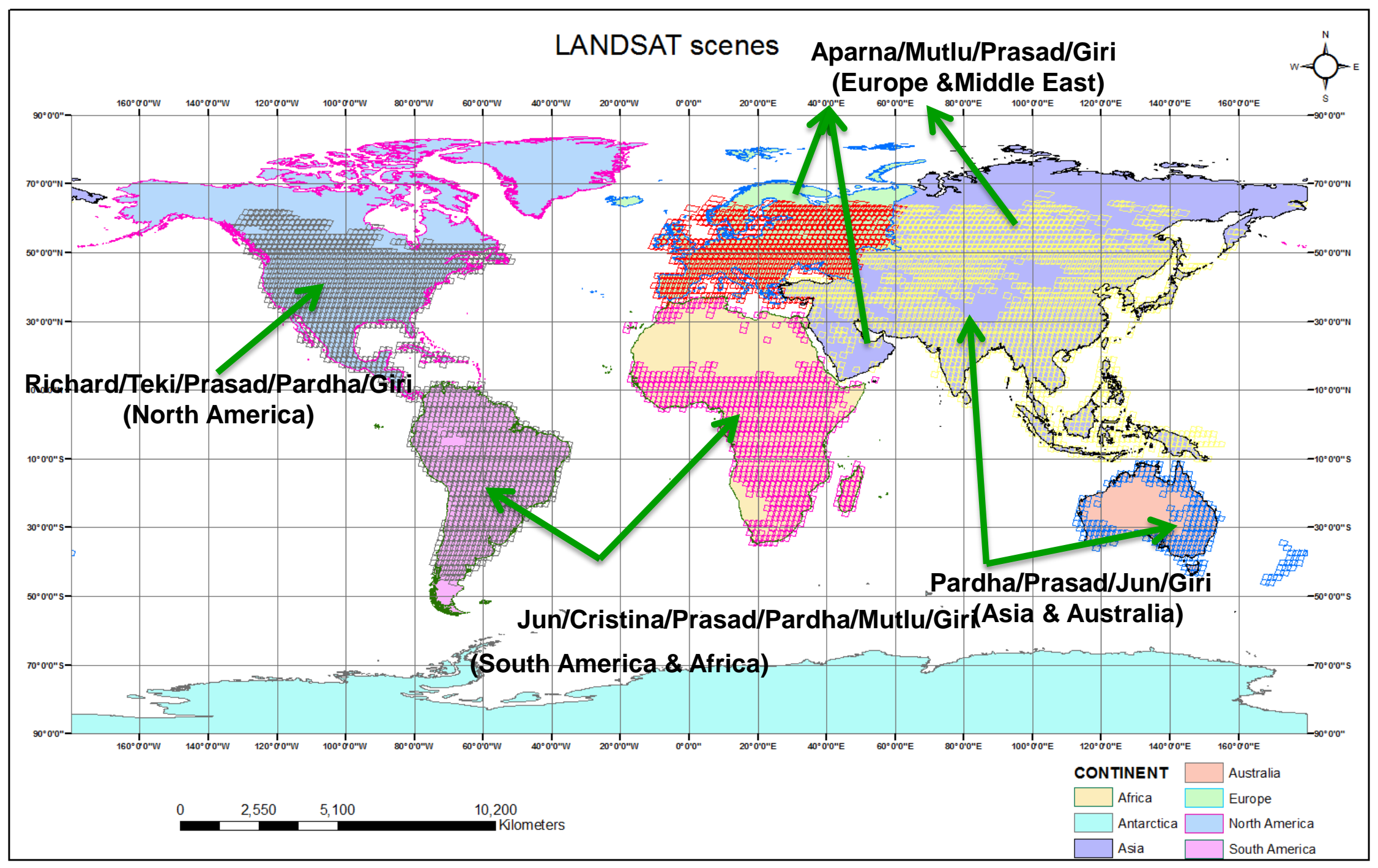




\section{GCE 30m Crop Dominance (aka GCE V3.0) @ nominal 30m Landsat Data of the World}

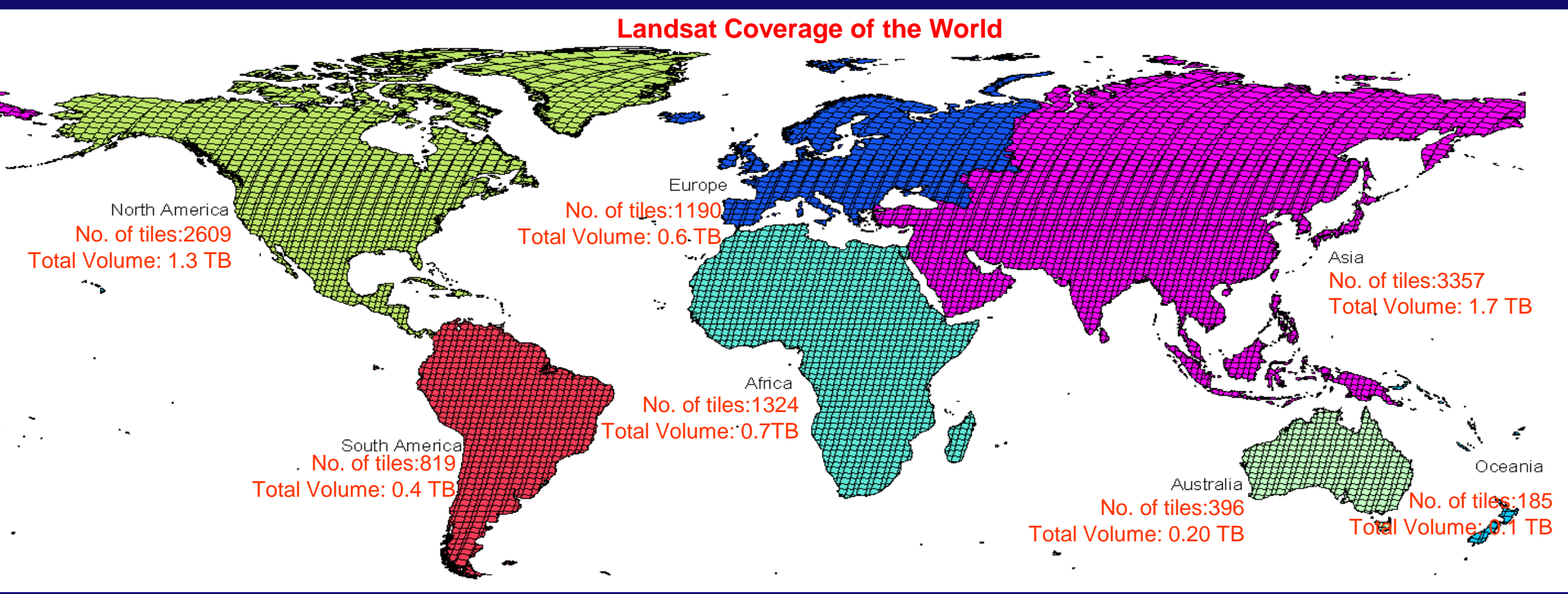

Total no of tiles needed: 9,770 (Digital number files) Average size of single tile: $500 \mathrm{Mb}$ (excluding thermal and panchromatic bands) Total volume for the Globe*: 4.8 TB (DN Images) Total volume for the Globe: 20.0 TB (Reflectance Images) \# 
Web-enabled (free) Landsat Data and Rapid Generation Products via Supercomputers NASA AMES NEX supercomputer and Google Earth Engine to Enable Computing Power

\section{http://earthexplorer.usgs.gov; http://glovis.usgs.gov/}

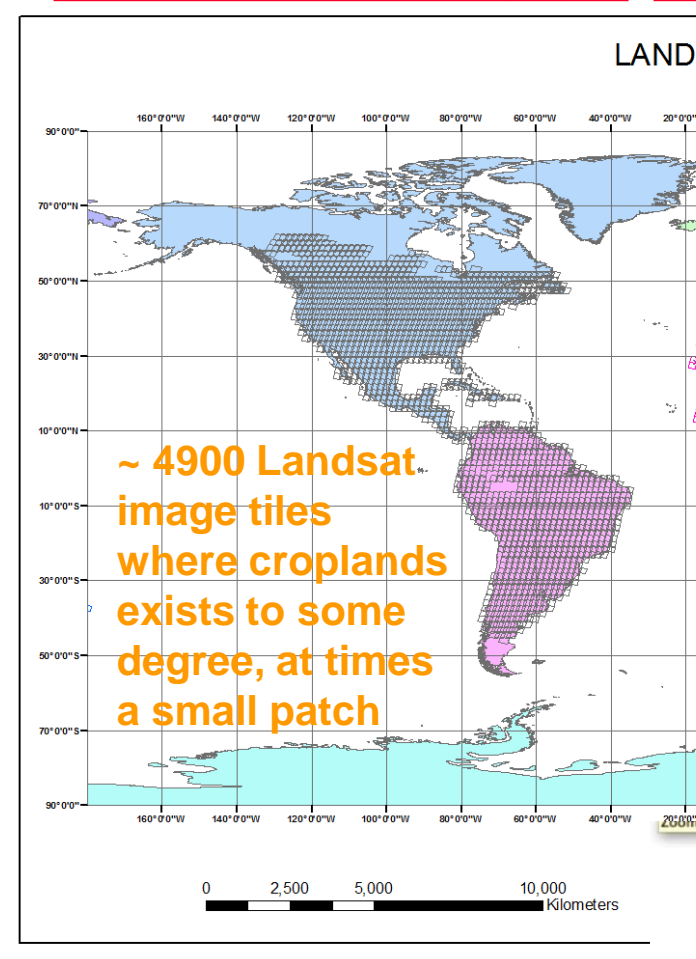

Ability to mosaic, run algorithms, and generate global products within few hours to few days.....challenge is to go from products like NDVI to Cropland Products (e.g., crop types, crop stressldrought, crop

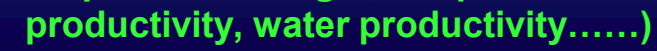
$\approx$ USGS

science for a changing world U.S. Geological Survey U.S. Department of Interior
NDVI

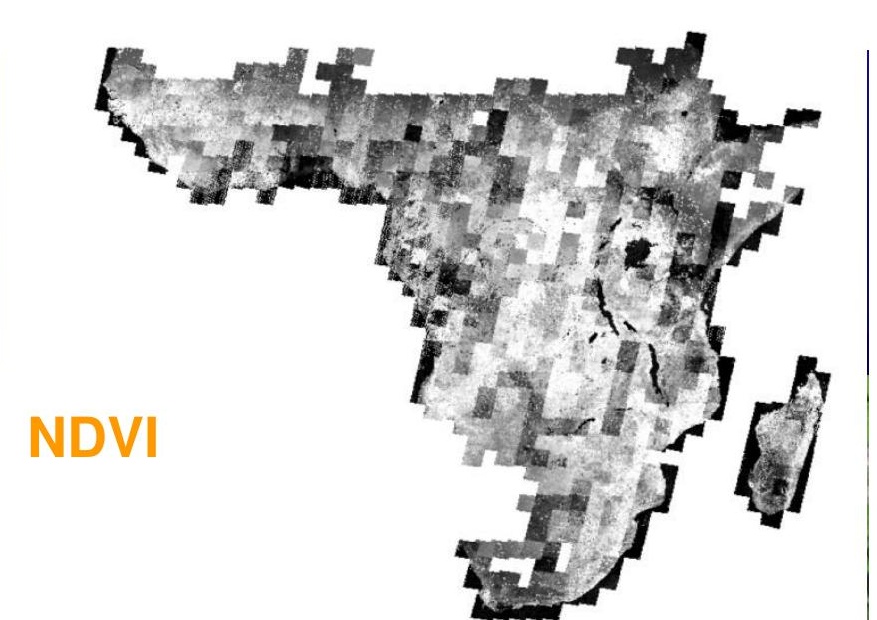

$20091114-52010050 \frac{42010092}{42} 7^{42011040}$

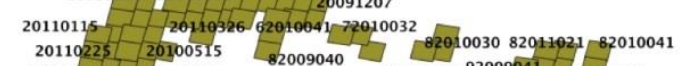
020101222009120420110227

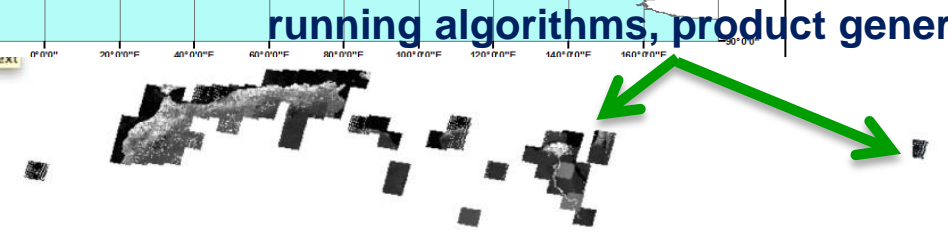

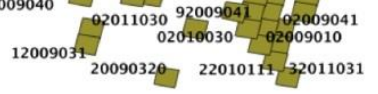

$20100227-20100220 \quad 20140321-20100209 \quad 82009020-\frac{72009041}{82011032}$ 20091006 02009110 $20091115-82010121 \quad 0201009192009021 / 02011032$

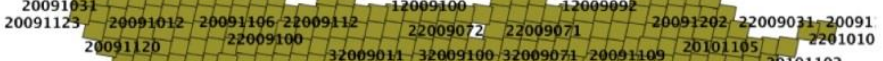

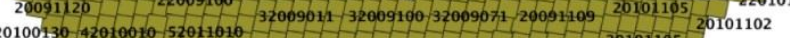

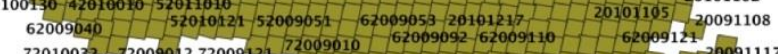

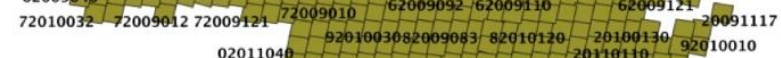

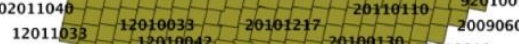
22011033 . 12010042 22010030 2010013022010010 $4201003232009052-20090625-20090701$ \begin{tabular}{r|c|c|c|c|c|}
\hline 62010051 & 20090702 & 20090526 & 20100201 \\
72010051 & 20090520 & 2010707
\end{tabular}

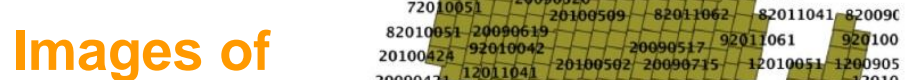

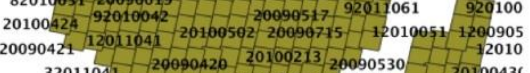

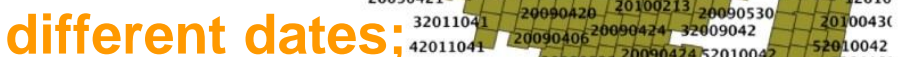

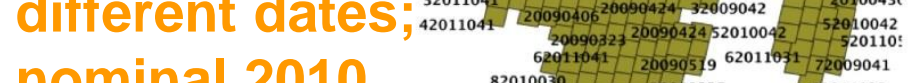
nominal 2010

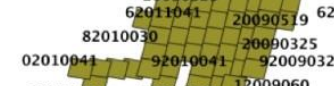
Data normalization, harmonization, mosaicking, $32010042-22009040-20100328$ 32010042 2011036 42010062
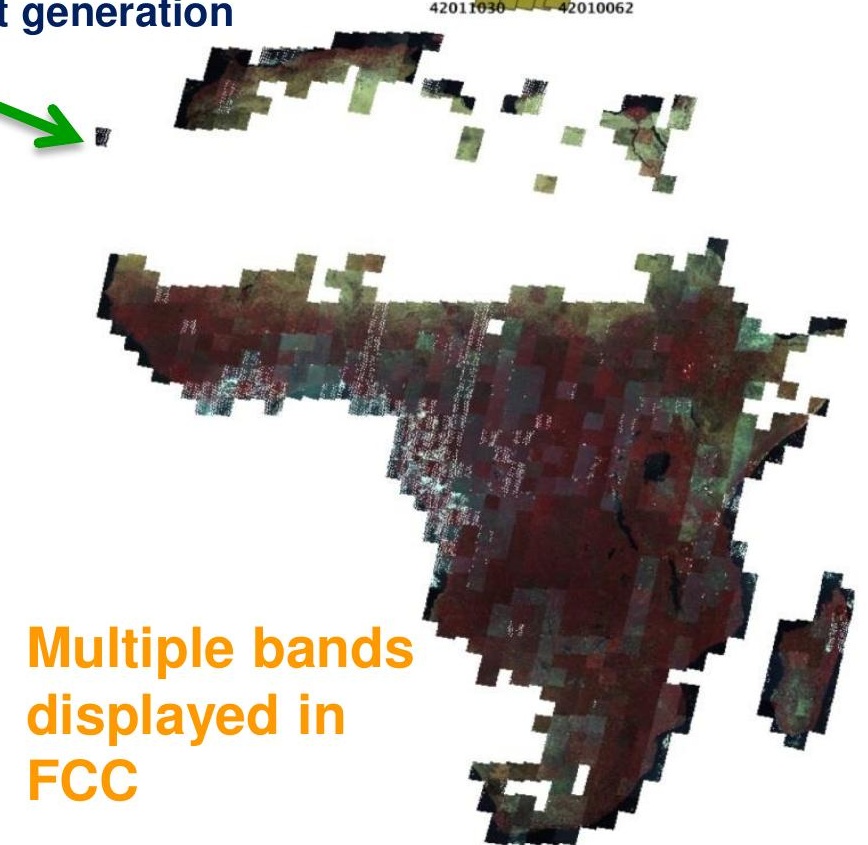


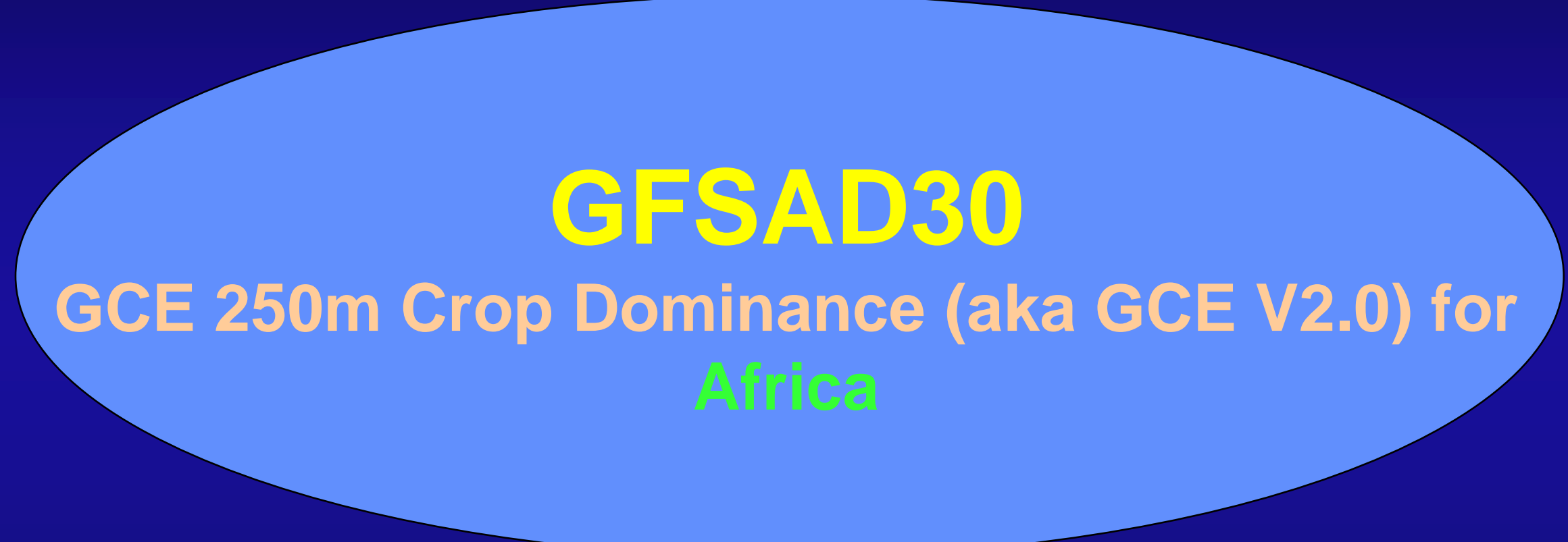

http://geography.wr.usgs.gov/science/croplands/index.html 
GCE $250 \mathrm{~m}$ Crop Dominance (aka GCE V2.0) @ nominal $250 \mathrm{~m}$ for Africa Africa is Growing at Rapid Phase and So is Agriculture

1. African population is expected to grow from little over 1 billion now to 4 billion by 2100 ;

2. Africa has hitherto been mostly limited to smallholder agriculture;

3. But, large farms are emerging, eventhough consequences of that is up for debate.

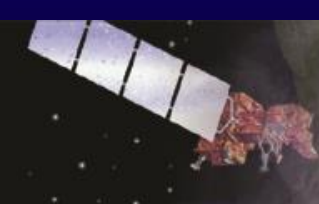


GCE 250m Crop Dominance (aka GCE V2.0) @ nominal 250 m for Africa Creating an Holistic System for Multi-Source Ground Knowledge to Overcome Complex Land Use Systems of Africa
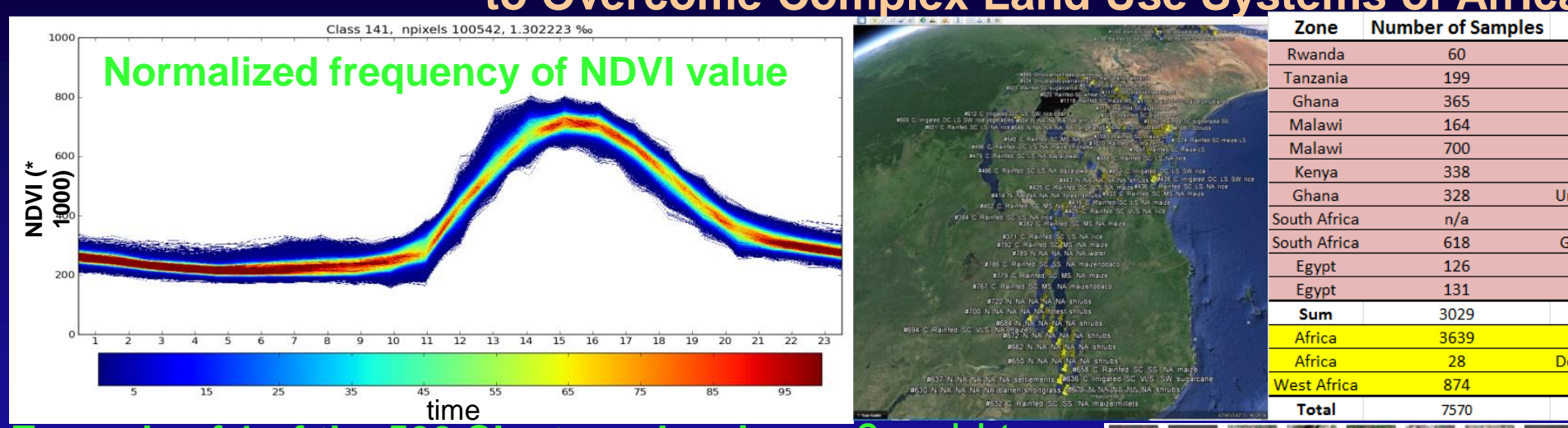

Ground data

collected by team

for all classes

Example of 1 of the 500 Clusters showing

11 year MODIS NDVI Times series in

Africa

Ground data

collected by team

for all classes

Provider

Date

\begin{tabular}{cccccc} 
Zone & Number of Samples & Provider & Date & Type & Field \\
\hline Rwanda & 60 & Murali & Nov-07 & Field Work & Full \\
\hline Tanzania & 199 & Murali & May-13 & Field Work & Full \\
\hline Ghana & 365 & Murali & Jun-08 & Field Work & Full \\
\hline Malawi & 164 & Murali & May-14 & Field Work & Full \\
\hline Malawi & 700 & Murali & May-14 & Field Work & Crop Types \\
\hline Kenya & 338 & Murali & Jun-14 & Field Work & Full \\
\hline Ghana & 328 & University of Ghana & Dec-12 & GIS polygons & Crop Types \\
\hline South Africa & n/a & AGIS & n/a & GIS & Crop Types \\
\hline South Africa & 618 & Google StreetView & \multicolumn{4}{c}{ Ground Photos } & Date, Location \\
\hline Egypt & 126 & Shalaby & Jun-05 & Landsat Class Map & LU \\
\hline Egypt & 131 & Ayad & 2005 & Landsat Class Map & LU \\
\hline Sum & 3029 & \multicolumn{5}{|l}{} & \\
\hline Africa & 3639 & Geo Wiki & n/a & user-submit & LU \\
\hline Africa & 28 & Degree_Confluence & n/a & user-submit & LU \\
\hline West Africa & 874 & Thenkabail & before 2000 & Field Work & Full \\
\hline Total & 7570 & \multicolumn{5}{l}{} & \\
\hline
\end{tabular}

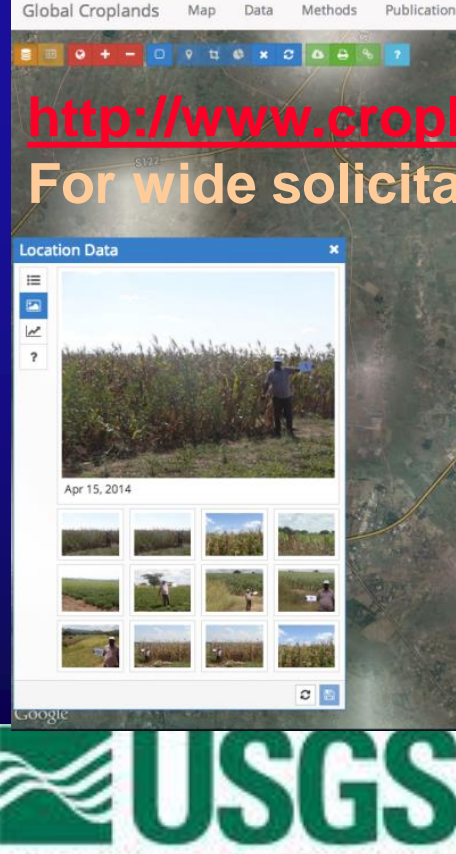

science for a changing world

U.S. Geological Survey

U.S. Department of Interior

Credits: Jun Xiong et al.

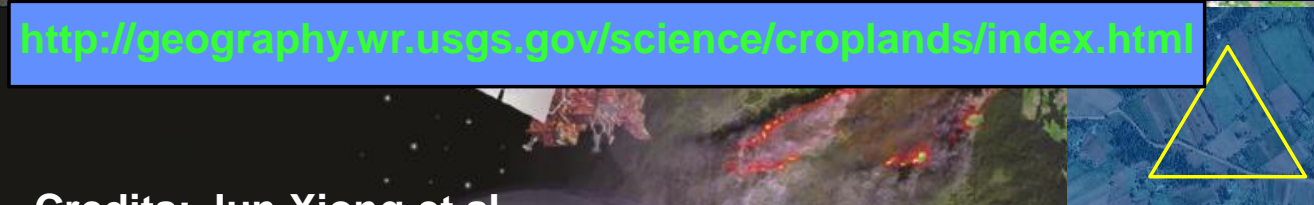

Example: gathering data from

$\Delta 4,4, \quad$ homogeneous pixels for cropland

$-1,4 d, 4$ and VHRI

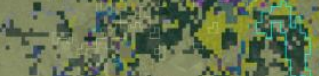


GCE 250m Crop Dominance (aka GCE V2.0) @ nominal 250 m for Africa Irrigated and Rainfed Croplands of Africa: Composite 2003-2013
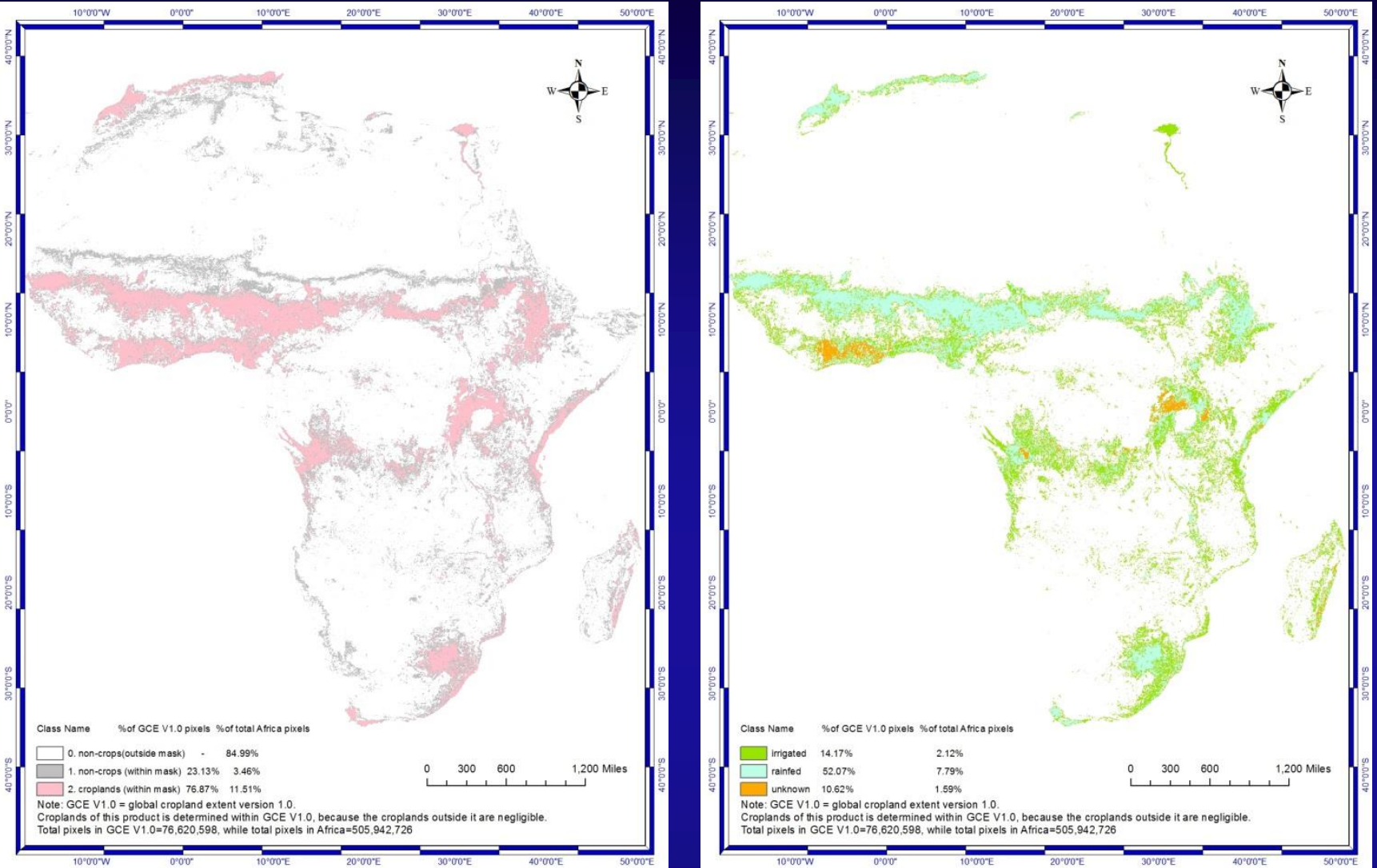

GCE 250m Crop Dominance (aka GCE V2.0) @ nominal $250 \mathrm{~m}$ for Africa provides 1. Croplands vs. non croplands;

2. Irrigation vs. rainfed;

3. Cropping intensity (single, double, continuous);

4. Crop type andlor dominance 
GCE 250m Crop Dominance (aka GCE V2.0) @ nominal 250 m for Africa Irrigated and Rainfed Croplands of Africa: Composite 2003-2013
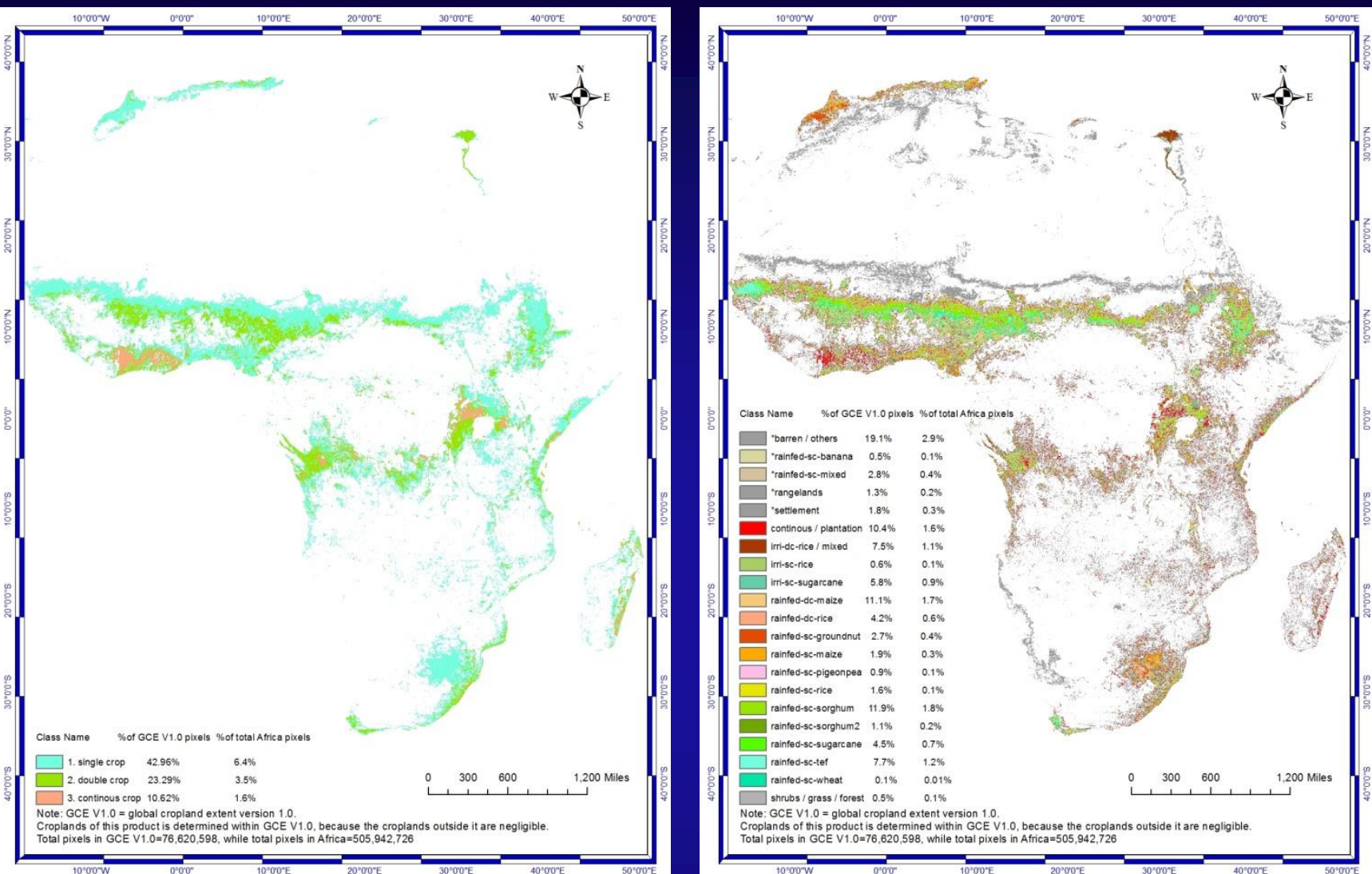

GCE 250m Crop Dominance (aka GCE V2.0) @ nominal $250 \mathrm{~m}$ for Africa provides 1. Croplands vs. non croplands;

2. Irrigation vs. rainfed;

3. Cropping intensity (single, double, continuous);

4. Grop type andlor dominance 
Automated Cropland Classification Algorithm (ACCA) for Croplands, Irrigated, Rainfed Algorithm Development based on MODIS, Landsat, and Secondary Data
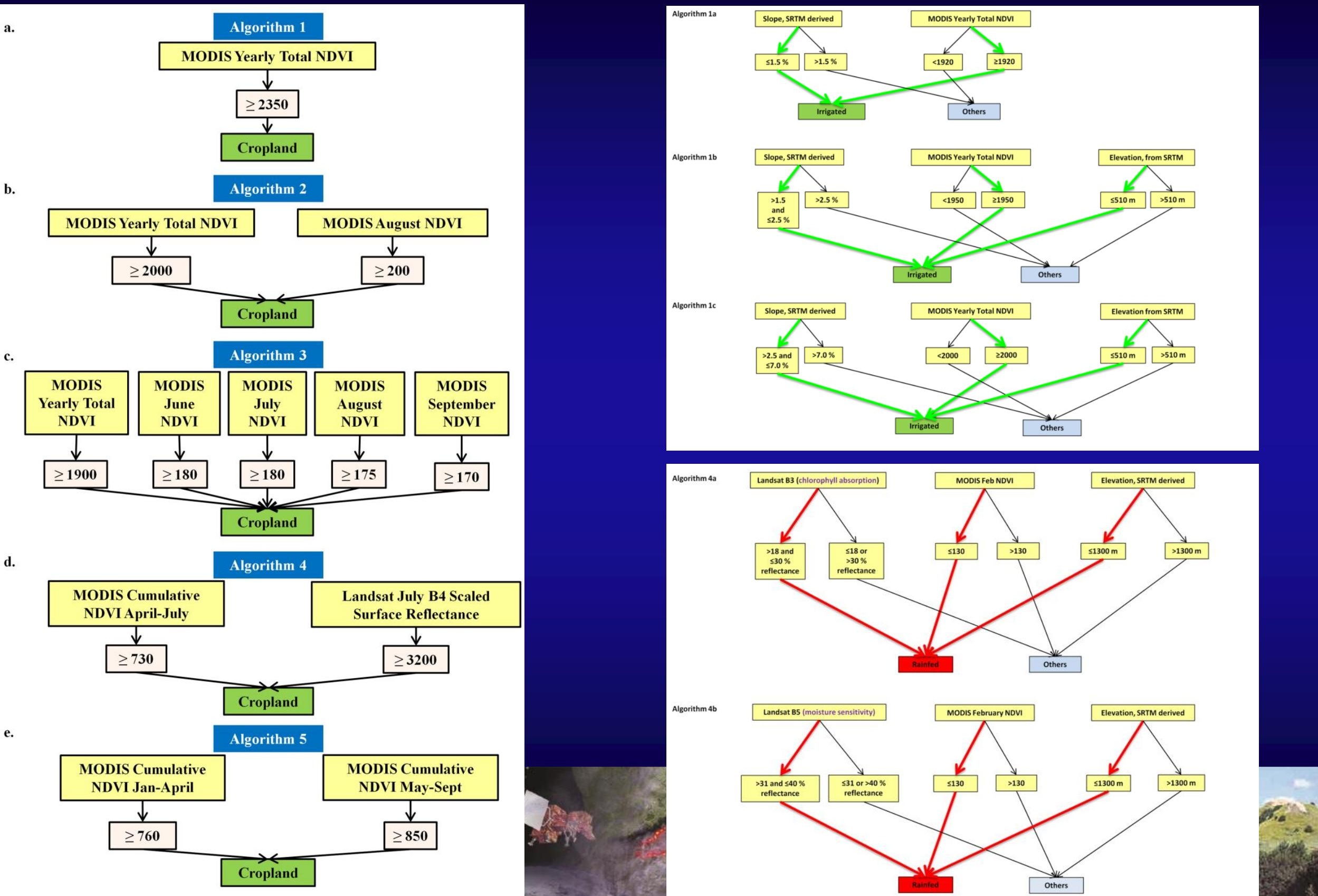
Global Food Security-support Analysis Data @ 30 m (GFSAD30) Project Ground Data from Numerous Sources

1. Existing ground data has been harmonized; 2. New ground data is being collected;

3. uploading ground data on GEE for sysnthesis and generating cropland signatures; 4. Development of a ground data App in progress
Ground reference data points (Global collection: Total 125796 points)

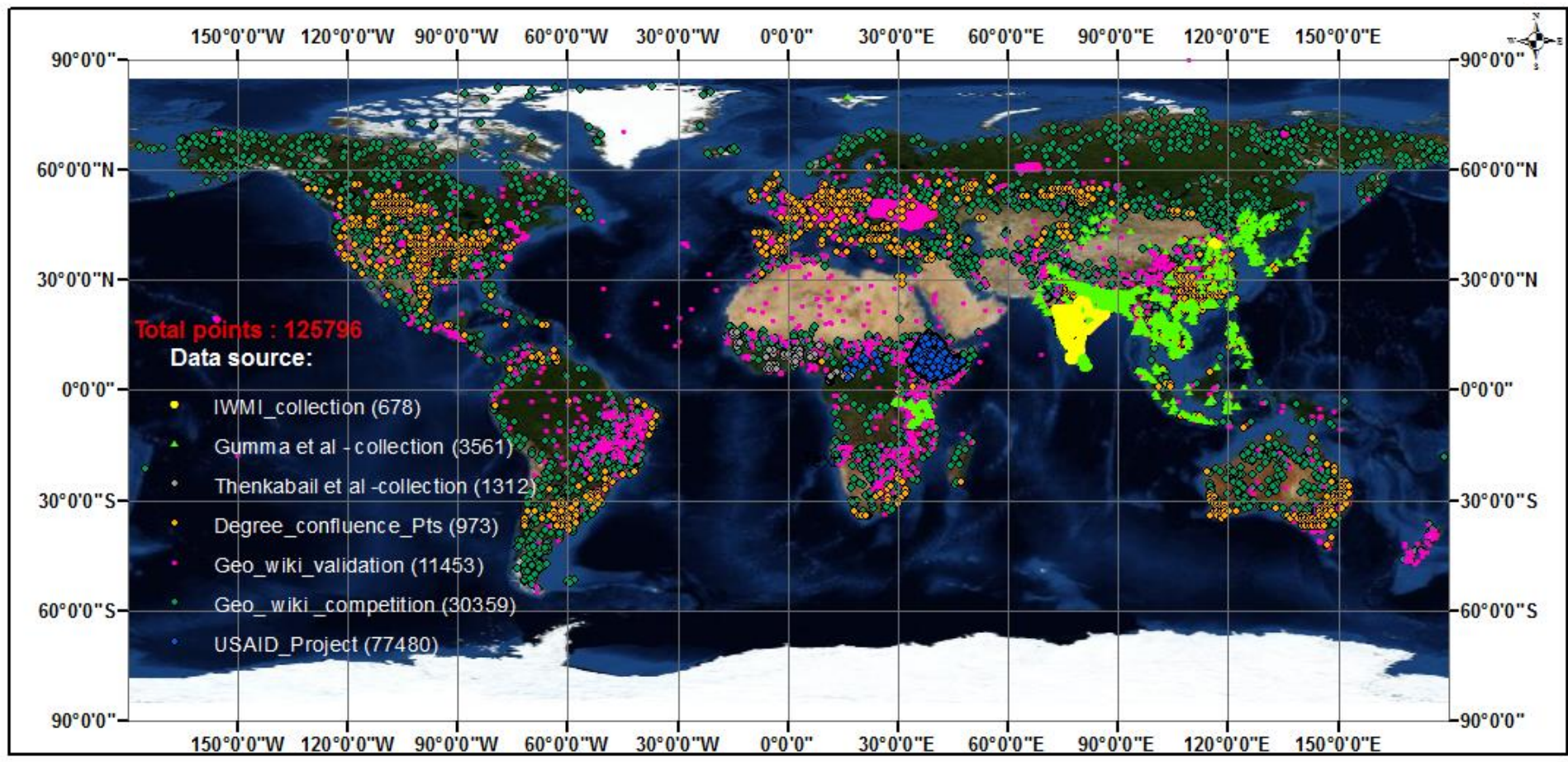

\section{http://www.croplands.org/}

Credits: Justin Poehnelt, Mutlu Ozdogan et al 
Collaborations for Validation and Feedback Recent

Recent (December, 2014 and Januarv-2015 ) Field Data in India; ICRISAT (Dr. Gumma)

ÆUSGS science for a changing world

U.S. Geological Survey U.S. Department of Inter

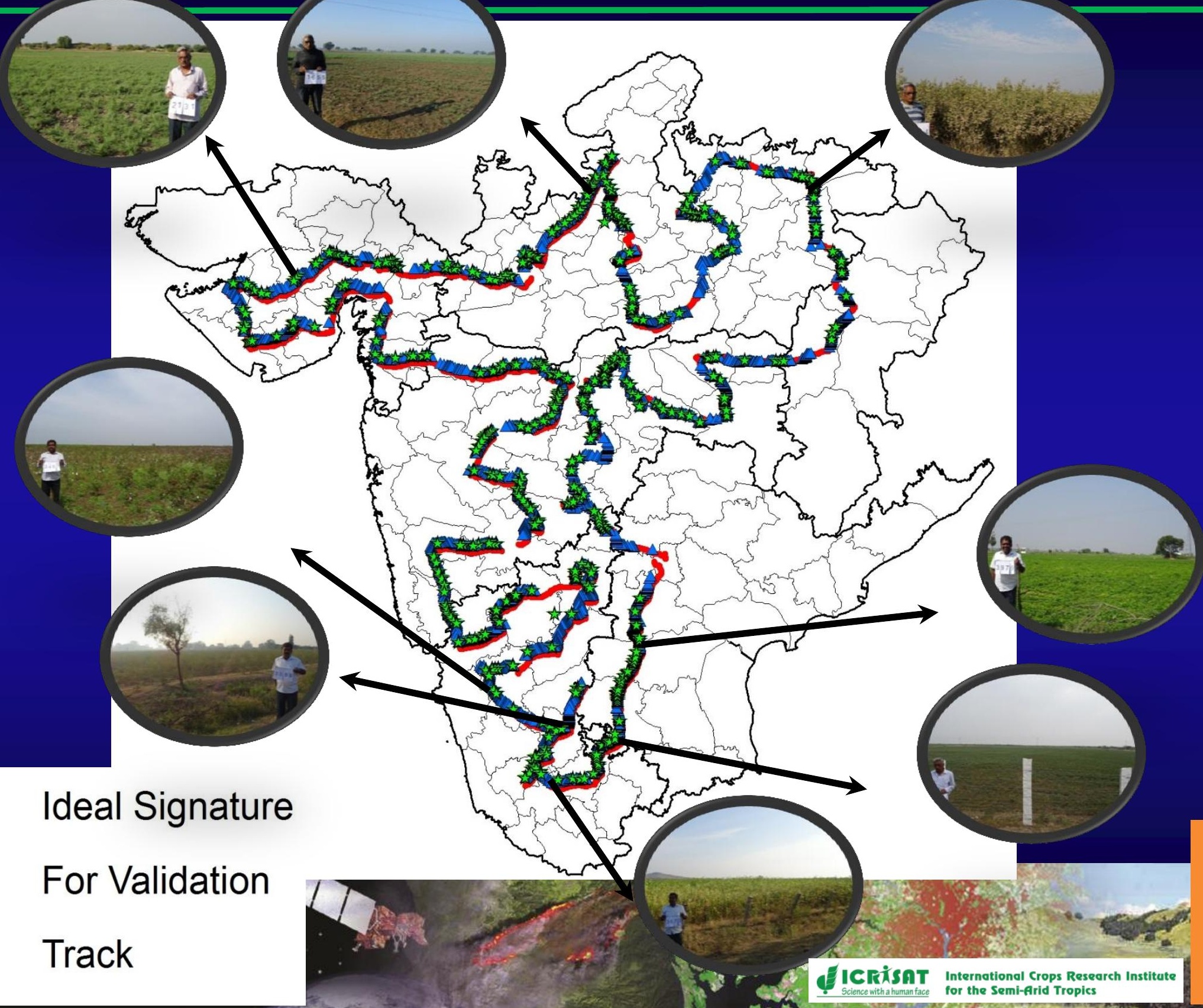


Recent (December, 2014 and January, 2015 ) Field Data in India; ICRISAT (Dr. Gumma)

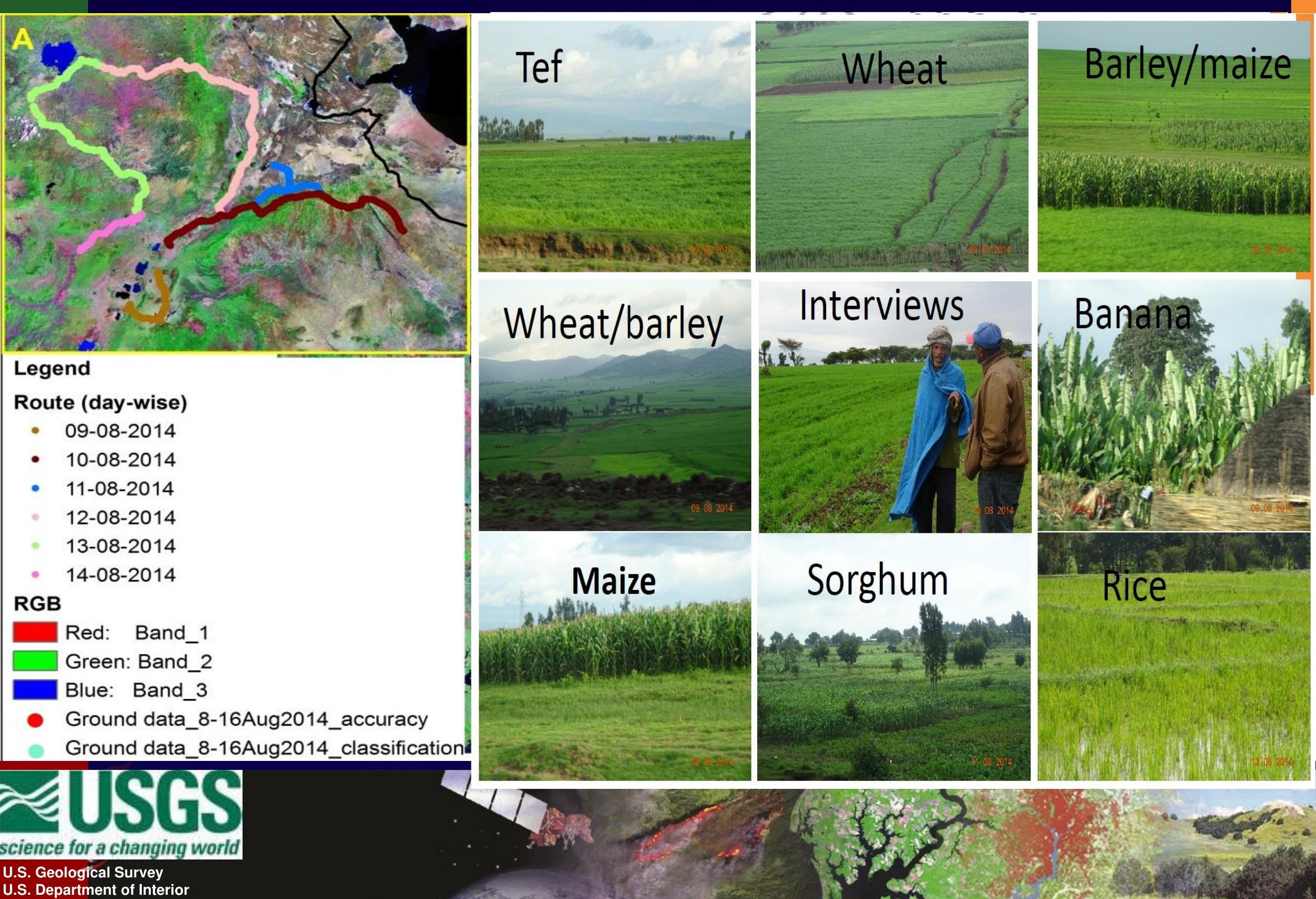




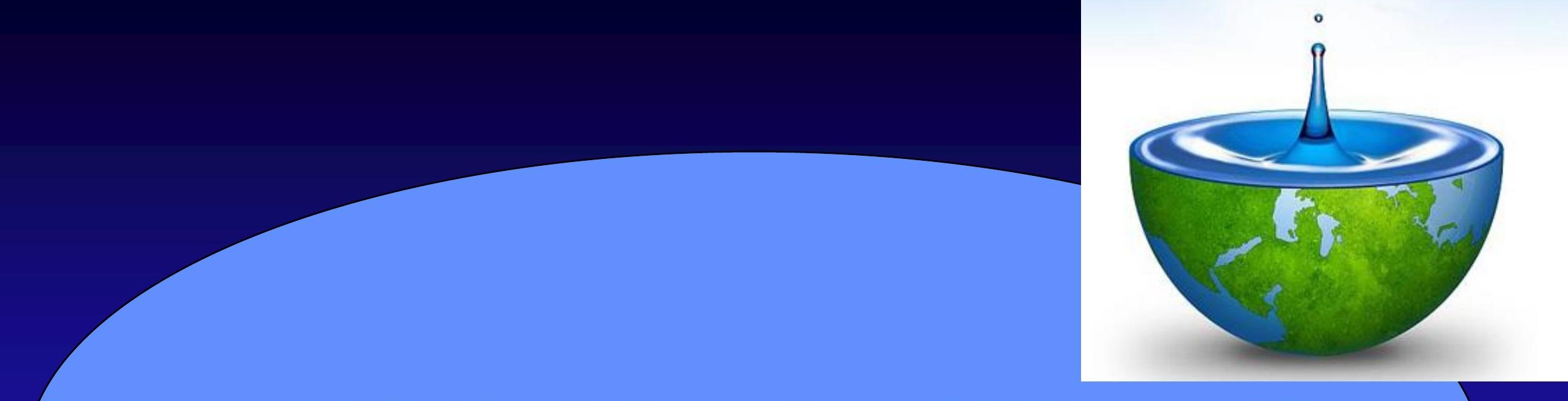
Role of Global Cropland Water Use in Ensuring Global Food Security

$\approx$ \#SGS

U.S. Geological Survey

U.S. Department of Interior

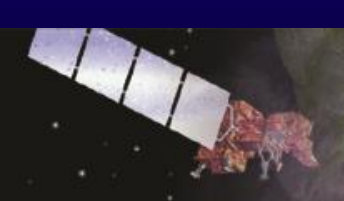


Blue water (from lakes, reservoirs, rivers, ground water) + Green Water (from soil moisture) use by croplands

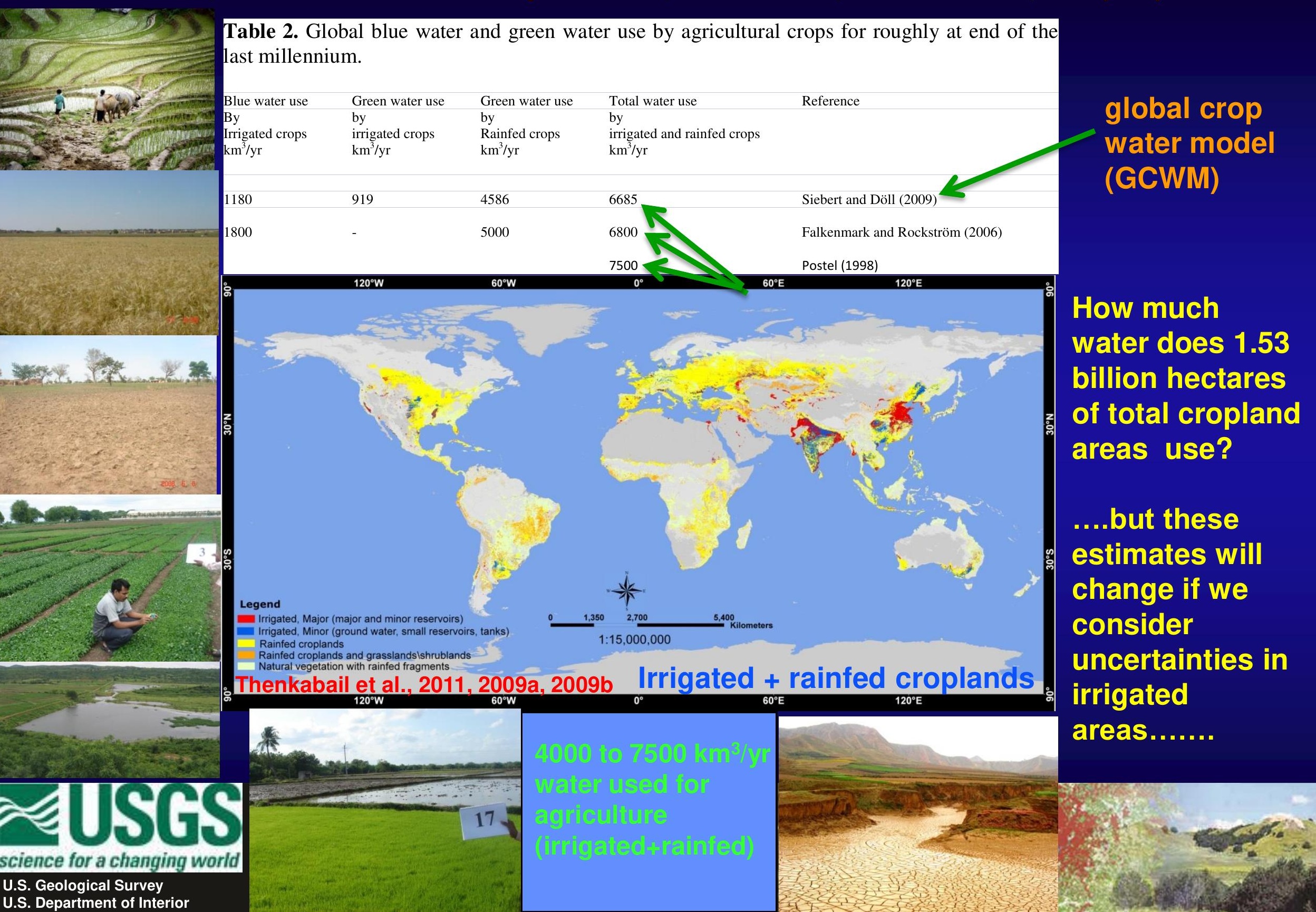




\section{Total Global Water Used by Rainfed Croplands}

Green Water (from soil moisture in unsaturated zone + direct rainfall on rainfed croplands) use by croplands

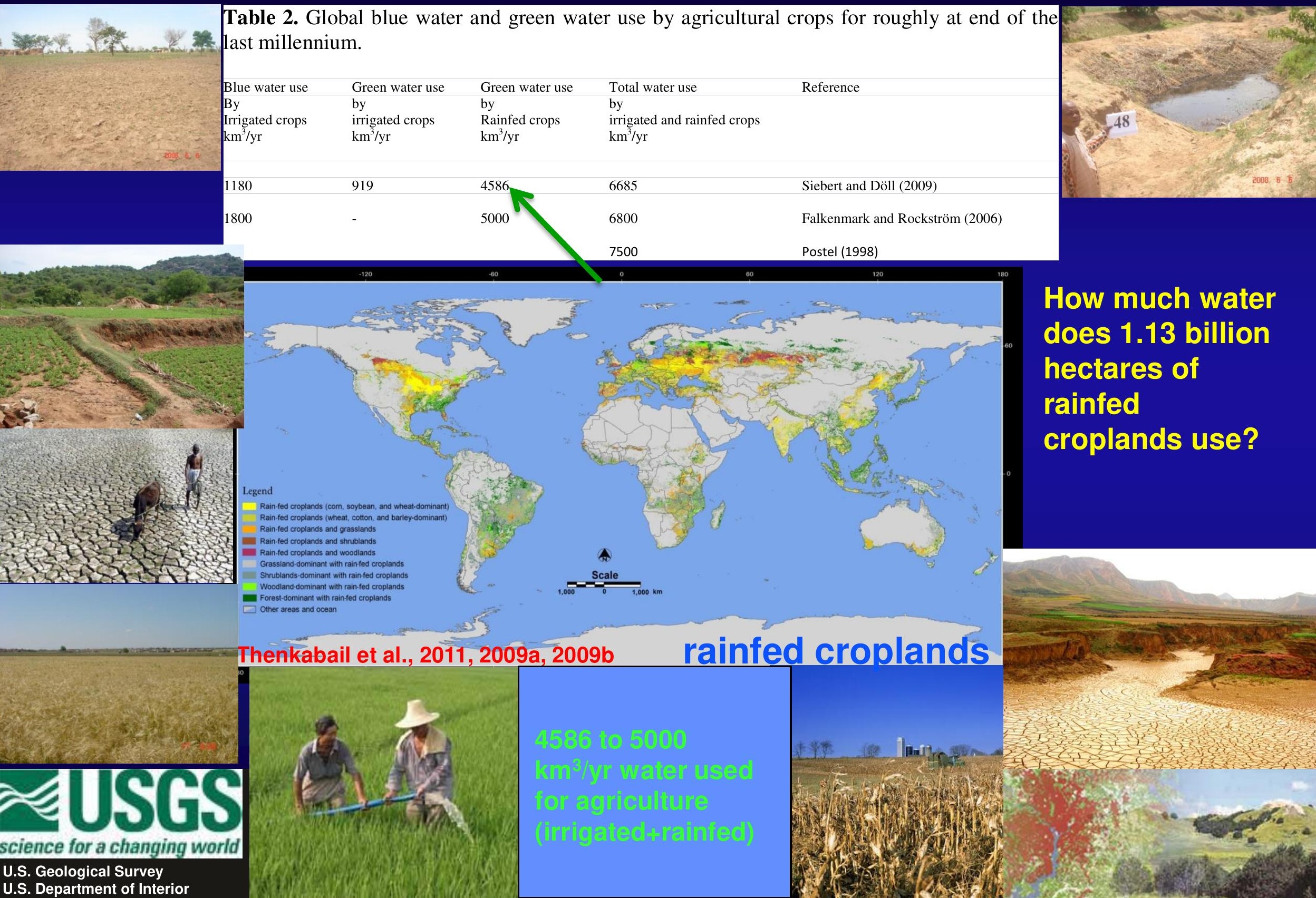


Blue water (from lakes, rivers, reservoirs, ground water) + direct rainfall over irrigated croplands

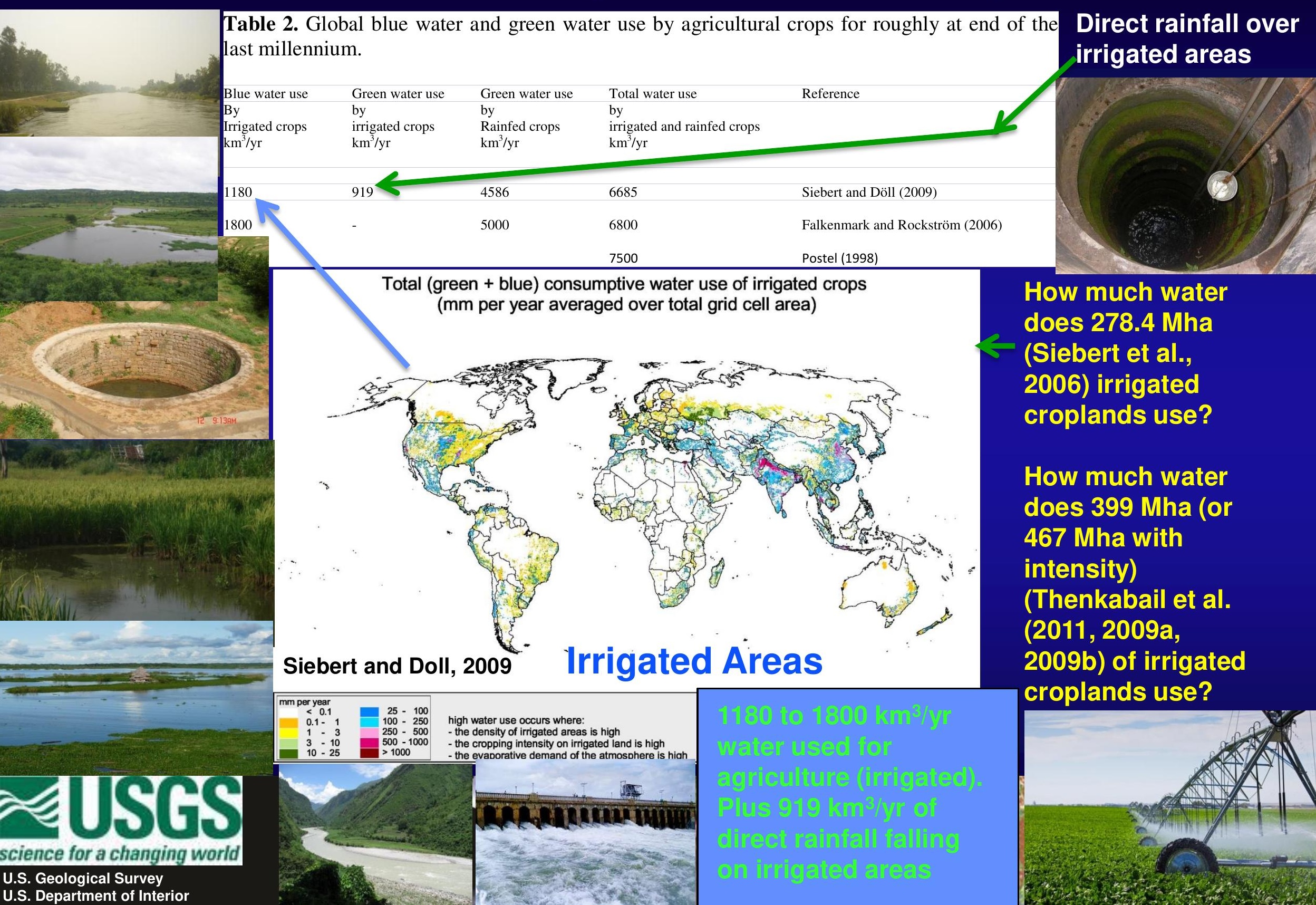




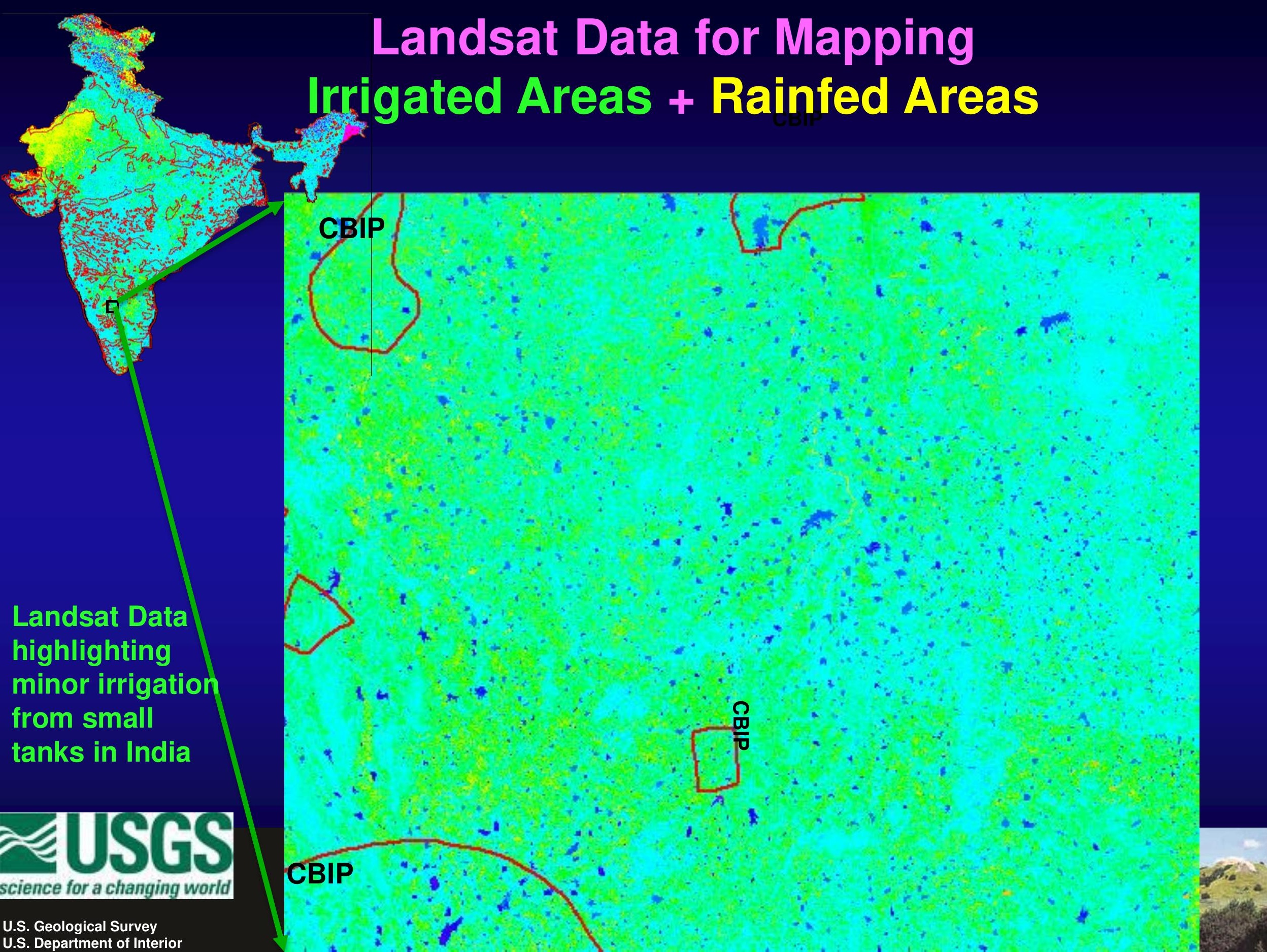


Global Food Security in the $21^{\text {st }}$ Century: Increasing Need of Cropland Areas and Agriculture Water for Food Security

\section{Desert Agriculture and Water Use}
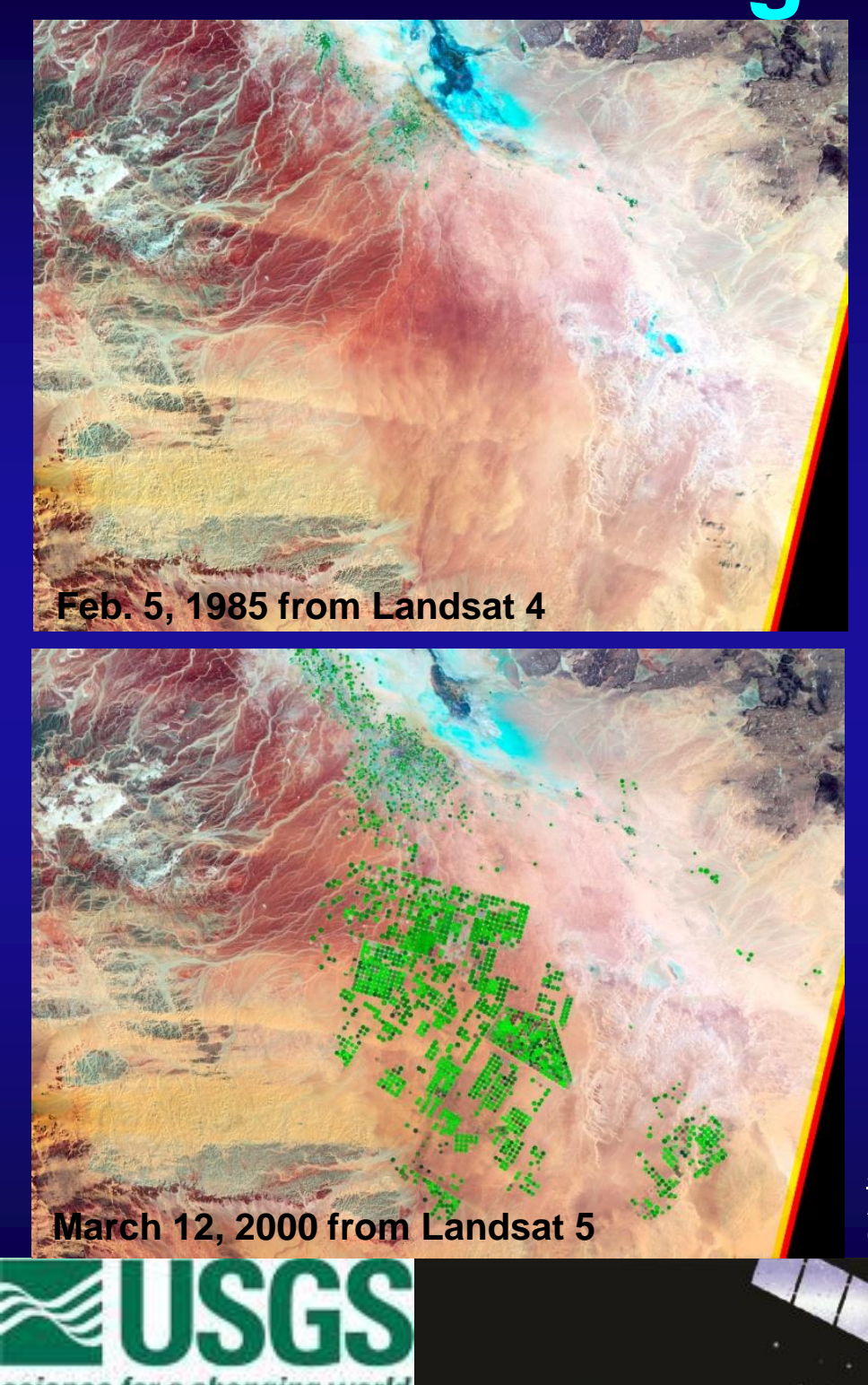

Each circle is 100 hectares of farmland. Uses ground water from 1-km deep wells. Desert agriculture water use in Saudi Arabia: 6.8 cubic kilometers in 1980 to 21 cubic kilometer in 2006. Rainfall just 100 to $200 \mathrm{~mm}$ per yr. Also, as per 2006 statistics of FAO, the Sudi Arabian Surface water resources was 2.4 cubic kilometers. However, annual water use was 23.7 cubic kilometers.

Source: Robert Simon and Jesse Allen. NASA Earth Observatory, $\mathrm{CIA}$, and FAO.

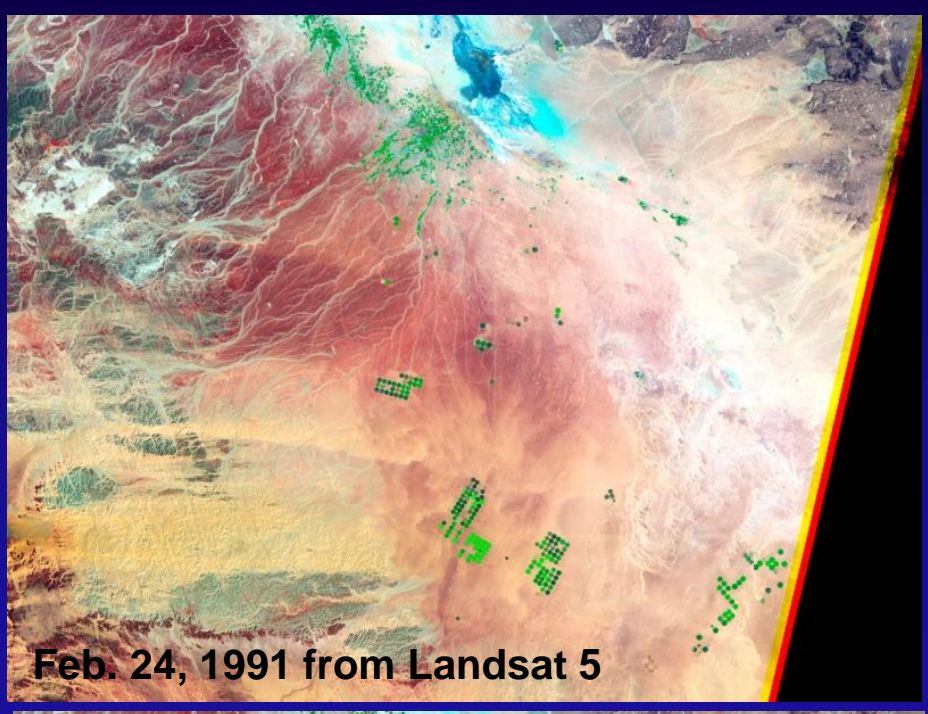

\section{Feb. 24, 1991 from Landsat 5}

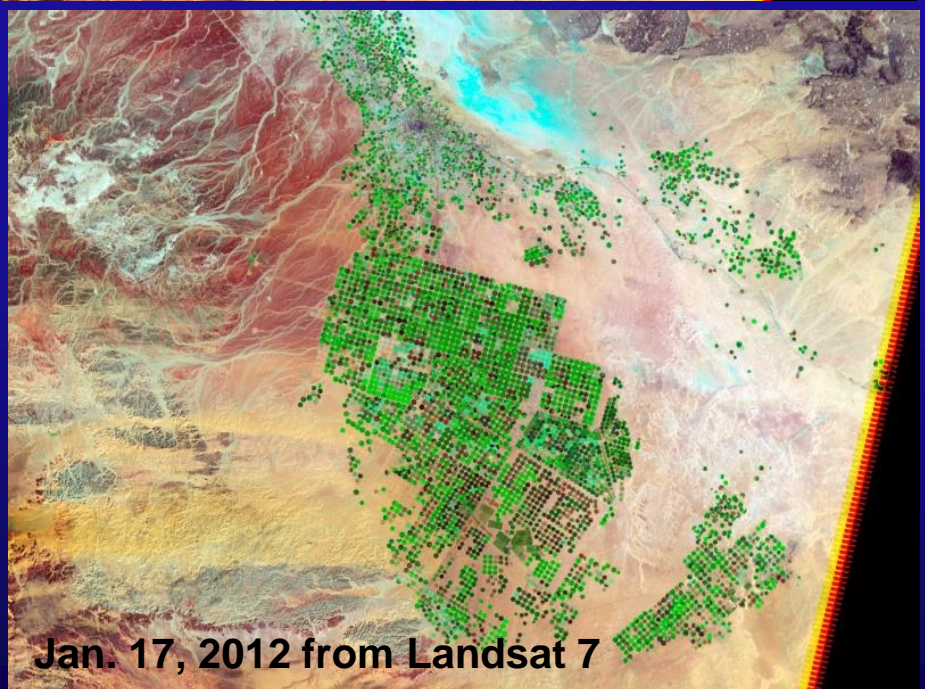

17,2012 from landsat 7

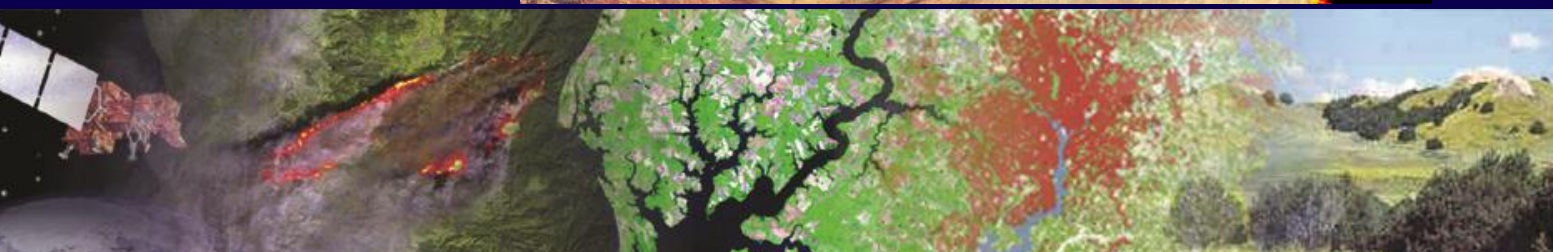


Global Food Security in the $21^{\text {st }}$ Century: Increasing Need of Cropland Areas and Agriculture Water for Food Security Virtual Water: Water Importers and Water Exporters in A Global Economy

잡

$\sim 20 \%$ of world's water use is virtual

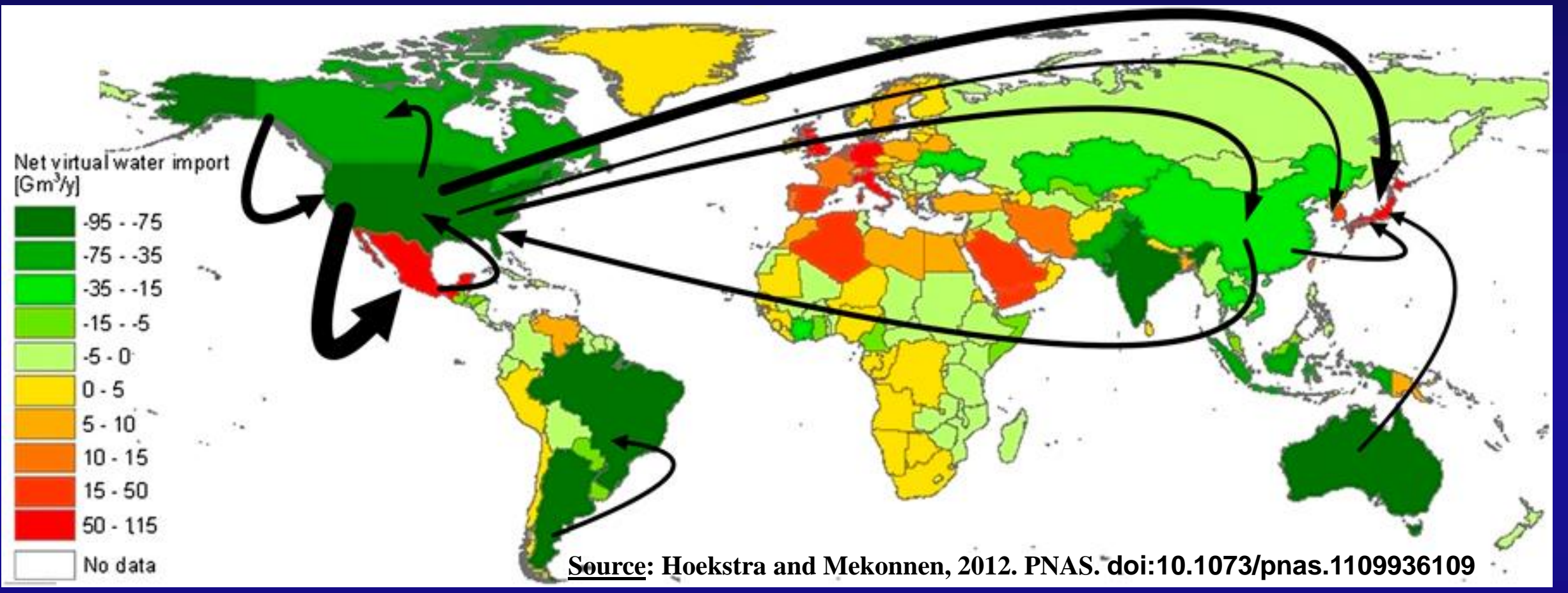

\section{Red: water importers; Green: water Exporters.}

\#USGS

science for a changing world U.S. Geological Survey

U.S. Department of Interior
Note: $1 \mathrm{Gm}^{3} / \mathrm{yr}$ (billion cubic meter per year)
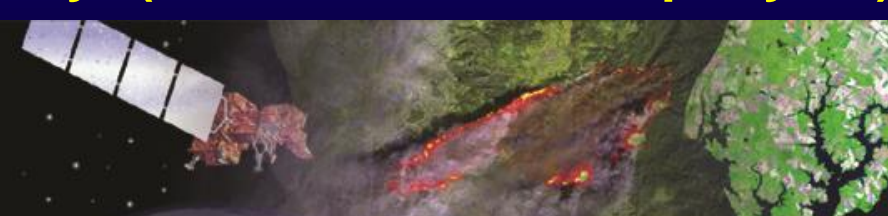


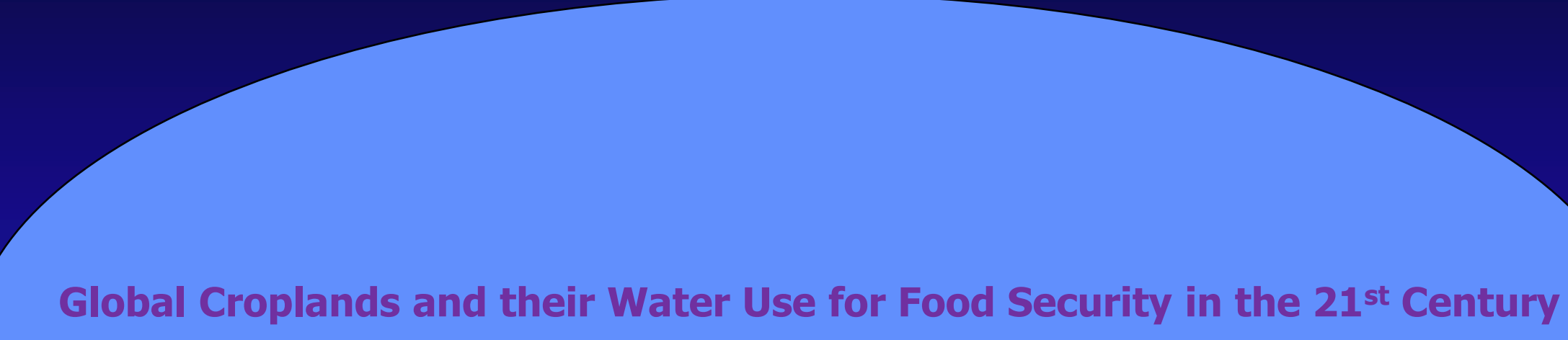

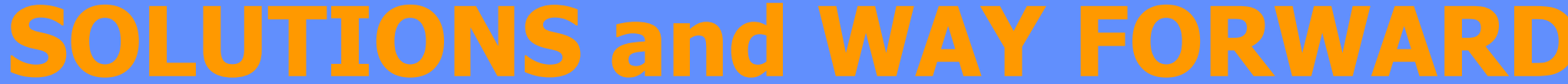


Global Food Security in the 21 $1^{\text {st }}$ Century: Increasing Need of Cropland Areas and Agriculture Water for Food Security Blue Revolution: Single Biggest Opportunity

Green revolution has virtually ended: the focus was on increasing productivity per unit of land $\left(\mathbf{k g} \backslash \mathrm{m}^{2}\right)$

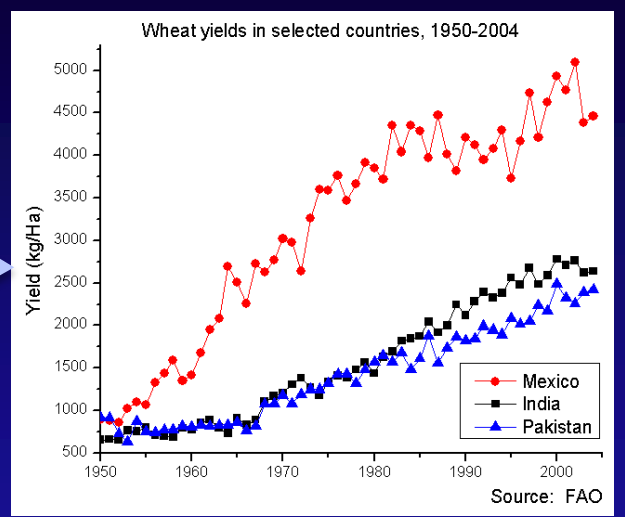

e.g., Wheat yield no more increasing....similarly, crop yields of other crops have stagnated. Similarly, 1. irrigated areas no more increasing; 2. croplands have stagnated; 3. increase in crop intensities have plateaued (also due to water limitations.

Blue revolution is in the nascent stage and offers the single biggest opportunity to grow more food from same land and water: the focus is on increasing productivity per unit of water $\left(\mathrm{kg} / \mathrm{m}^{3}\right)$ or crop per drop.

ÆUSGS

science for a changing world U.S. Geological Survey U.S. Department of Interior

\section{Liu, 2007 Crop Water Productivity of Wheat (2000)}

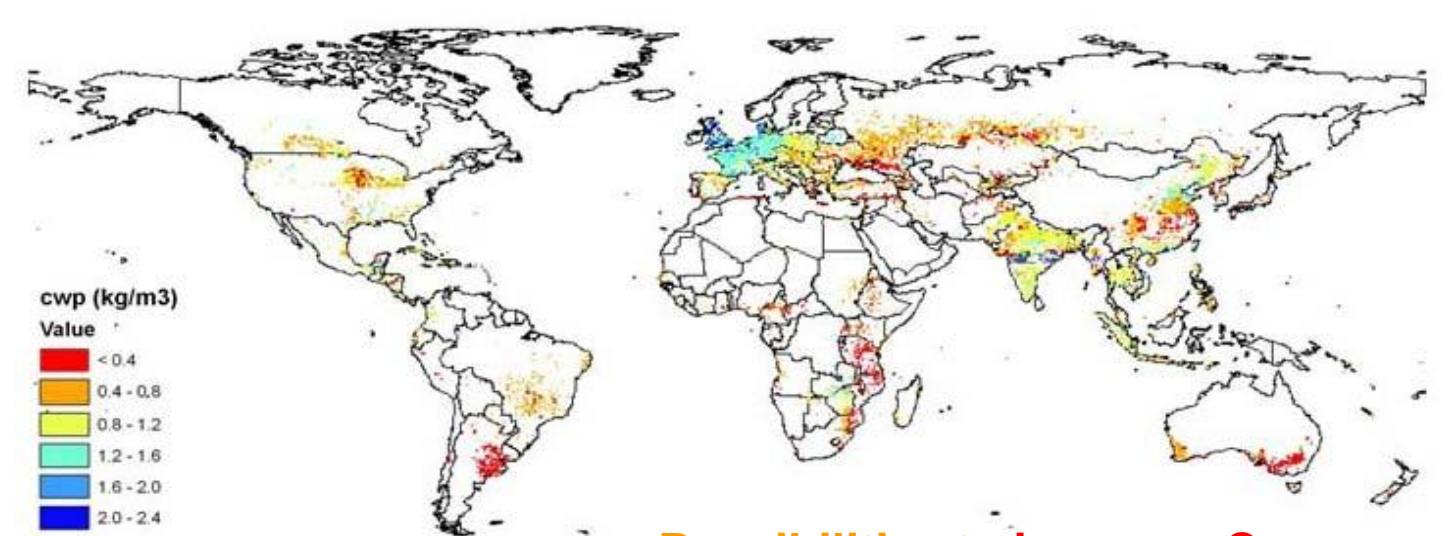

Possibilities to increase Crop per drop a ând grow moré food from sanas land and water is, possibly, the biggest and 
Global Food Security in the $21^{\text {st }}$ Century: Increasing Need of Cropland Areas and Agriculture Water for Food Security

\section{Ongoing USGS Mendenhall Research in California}
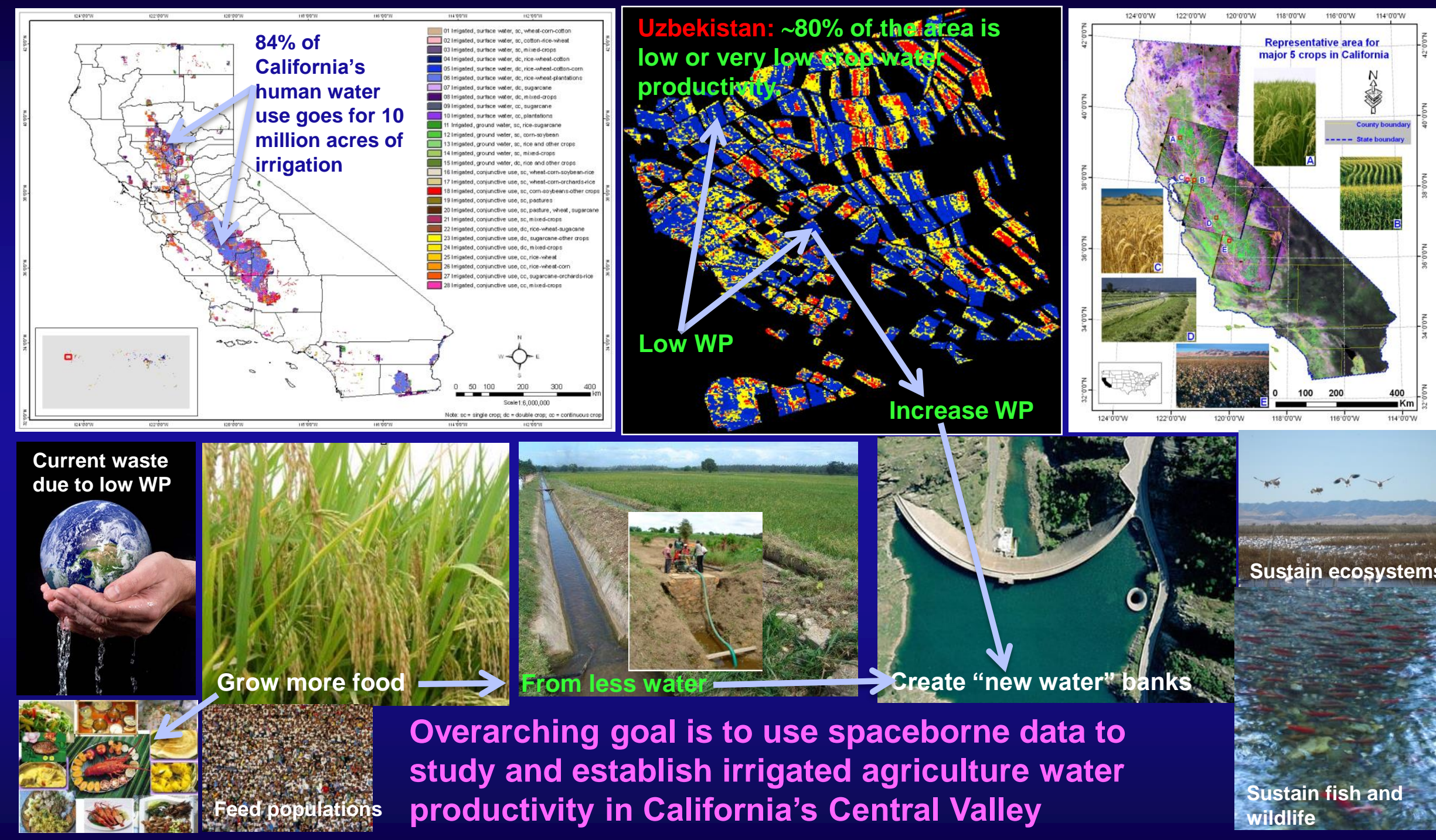

Overarching goal is to use spaceborne data to study and establish irrigated agriculture water productivity in California's Central Valley
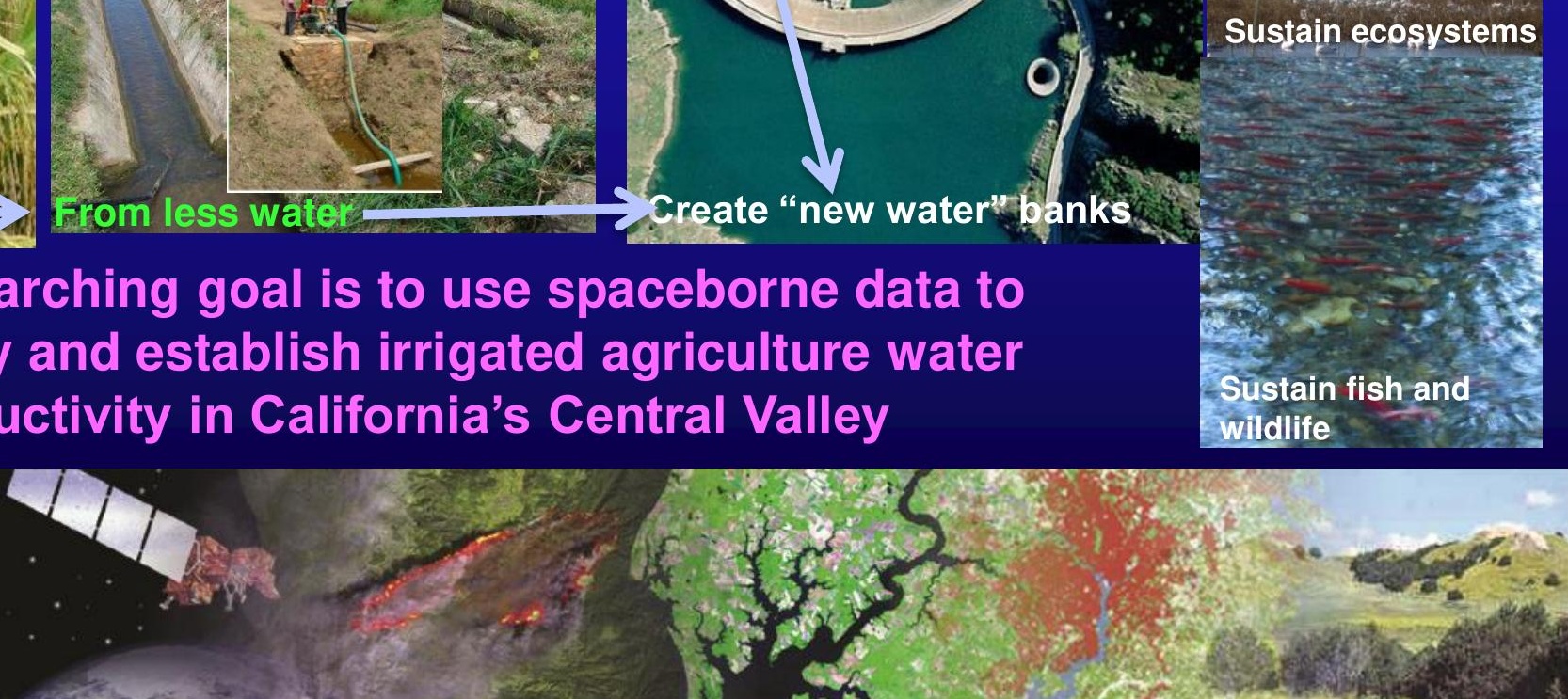
Global Food Security in the $21^{\text {st }}$ Century: Increasing Need of Cropland Areas and Agriculture Water for Food Security

\section{Focus on Key Crops for a Blue Revolution}

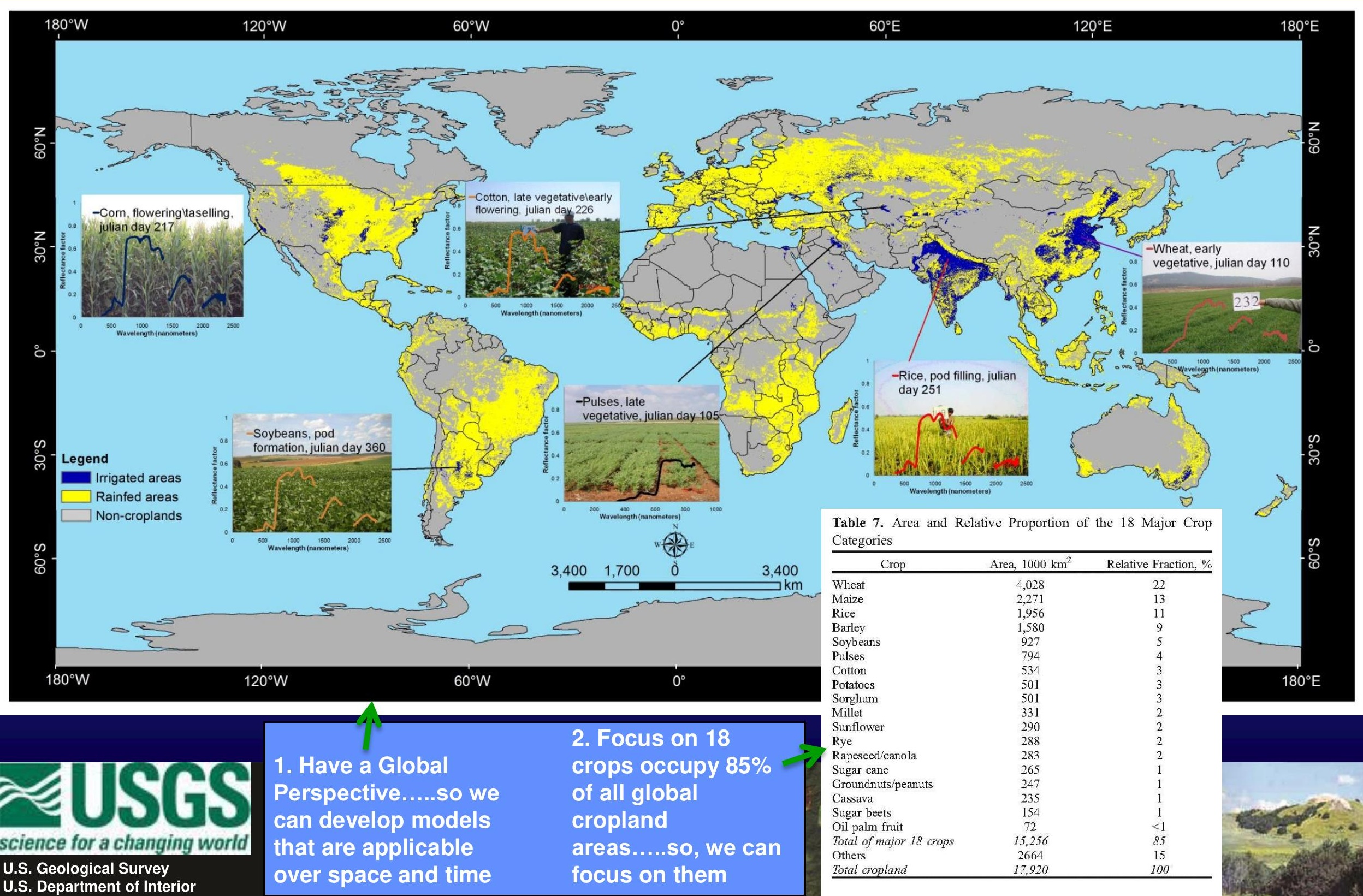


Global Food Security in the $21^{\text {st }}$ Century: Increasing Need of Cropland Areas and Agriculture Water for Food Security Continued Green Revolution: To Close the Yield Gap in Most of the Existing Croplands

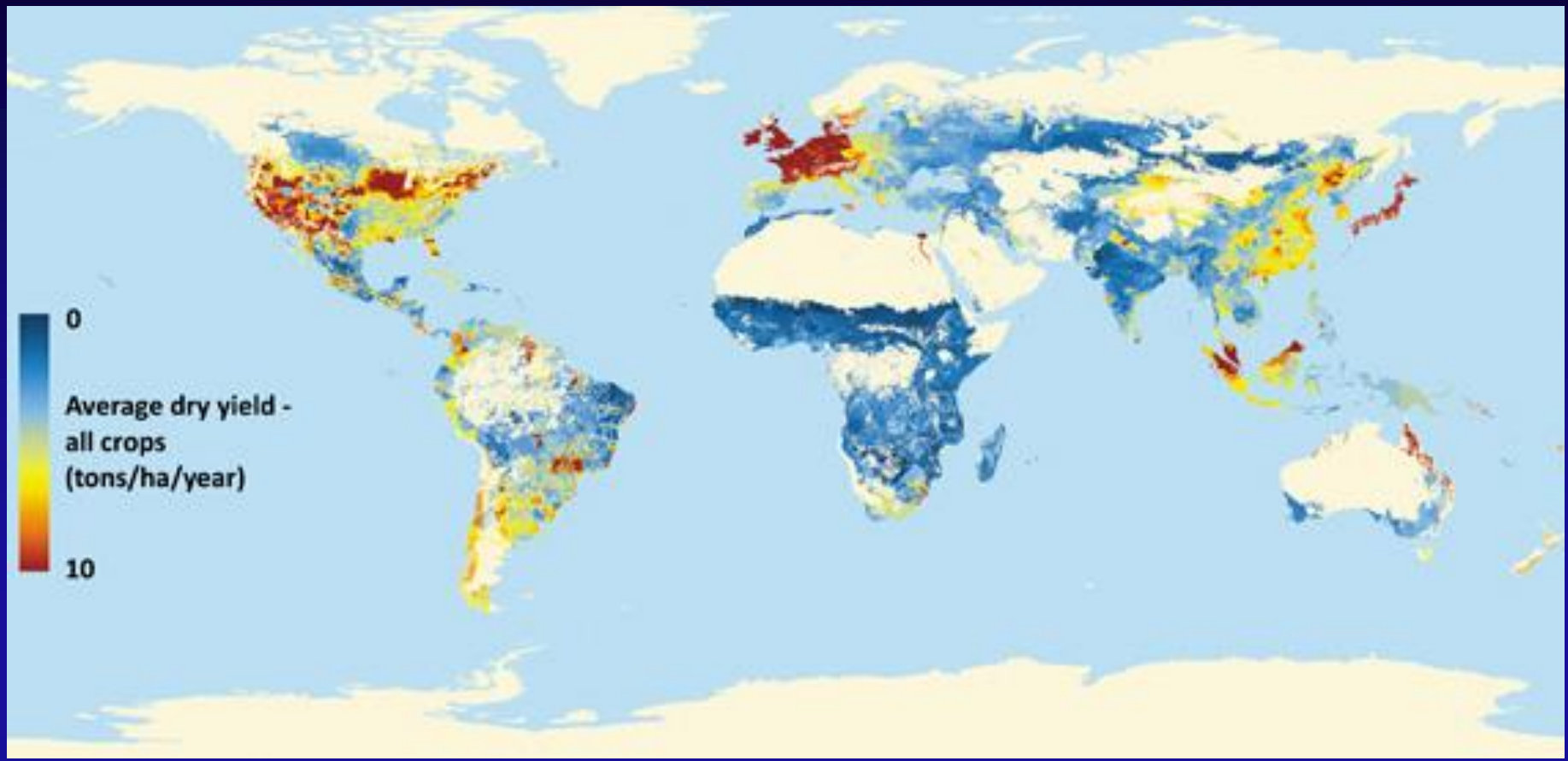

However, watch out for detrimental application of herbicides, pesticides, Nitrogen .....that invariably lead to polluted aquifers, loss of biodiversity (e.g., fish life), and degradation of soils.

Image Source: Paul C. West, Holly K. Gibbs, Chad Monfreda, John Wagner, Carol C. Barford, Stephen R. Carpenter, and Jonathan A. Foley. Trading carbon for food: Global comparison of carbon stocks vs. crop vields on agricultural land. PNAS. DOI: 10.1073/pnas.1011078107.
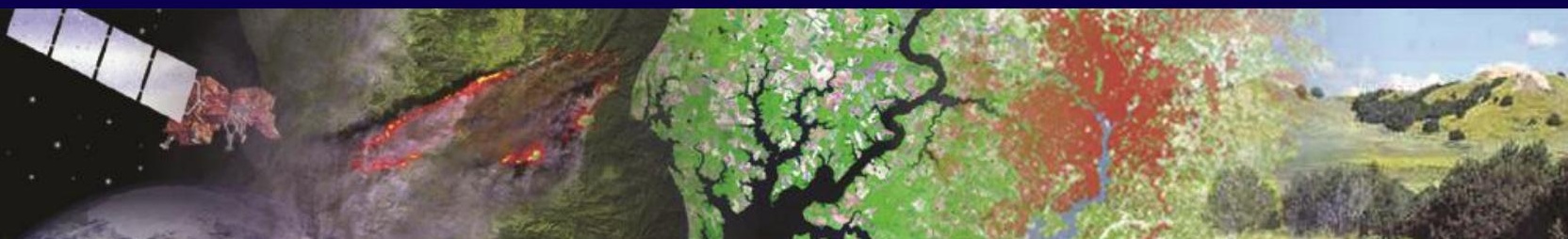
Global Food Security in the 21 $1^{\text {st }}$ Century: Increasing Need of Cropland Areas and Agriculture Water for Food Security Rainfed Croplands: Great Opportunity for Production Increase in 1.1 billion hectares
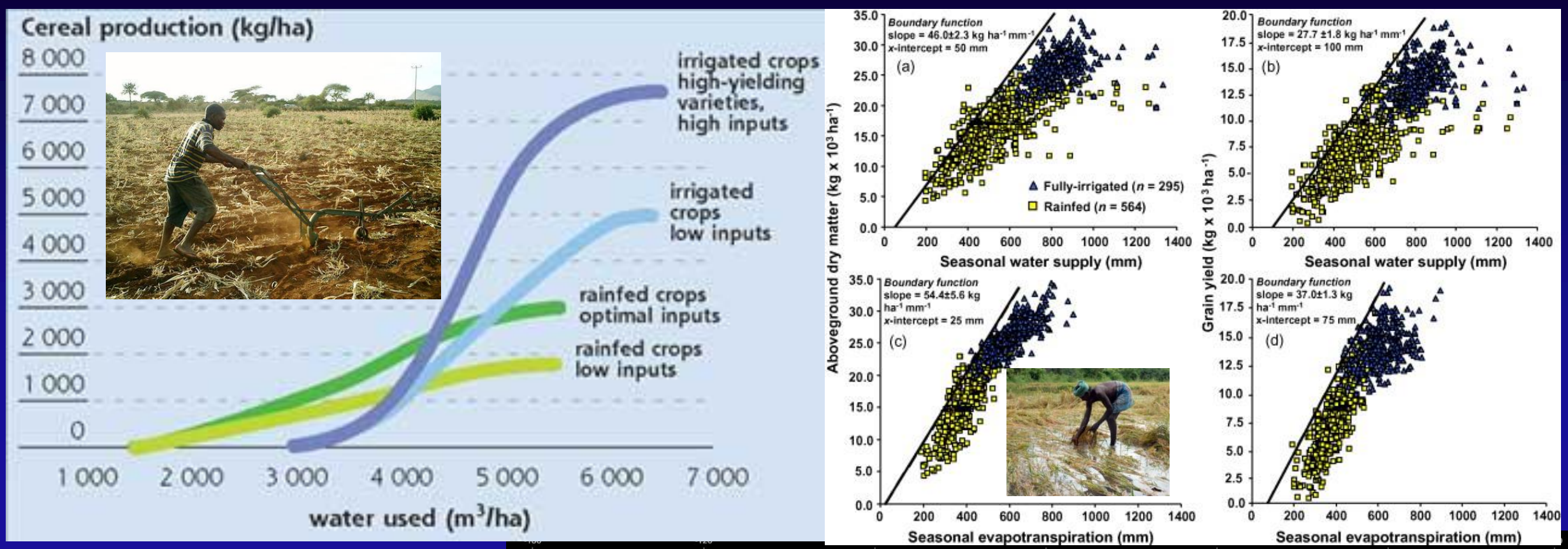

Yield gap in rainfed croplands relative to irrigated croplands is great. Further, there is tremendous scope for increasing the crop productivity and water productivity of rainfed croplands of the world. With 1.1 billion hectares of rainfed croplands this is one great opportunity to increase food production.
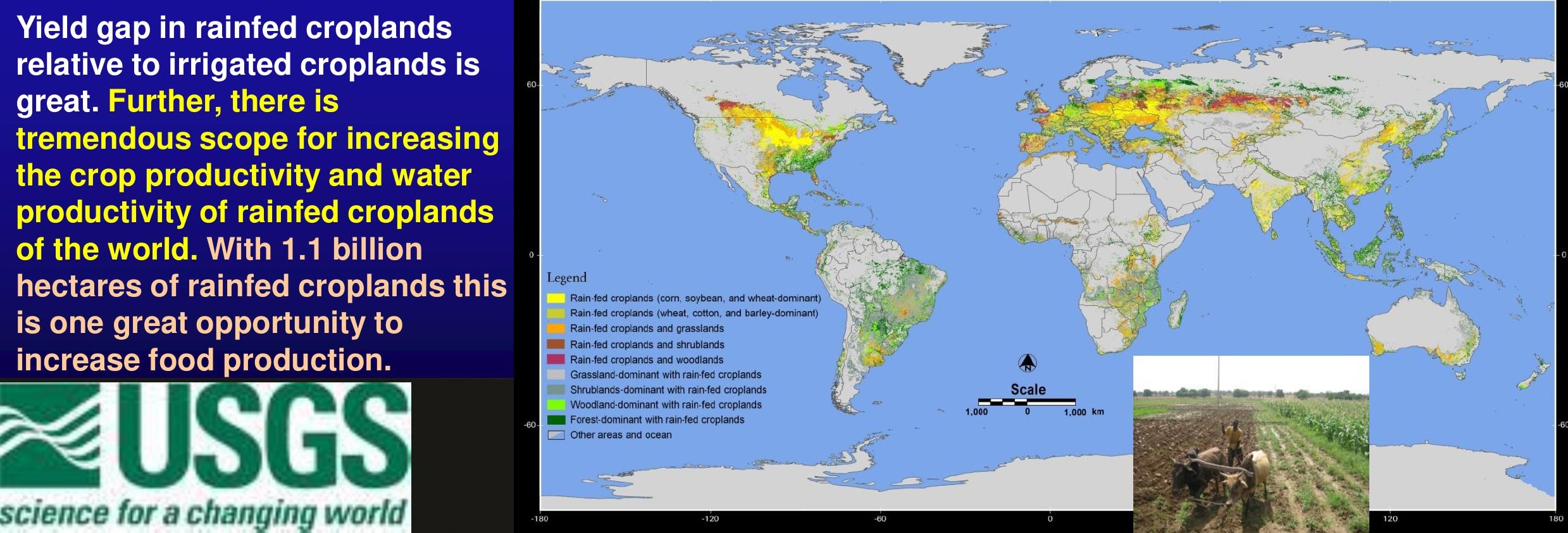
Global Food Security in the 21 $1^{\text {st }}$ Century: Increasing Need of Cropland Areas and Agriculture Water for Food Security Irrigation expansion in Africa?: Contributing to Africa's/Global Food Security

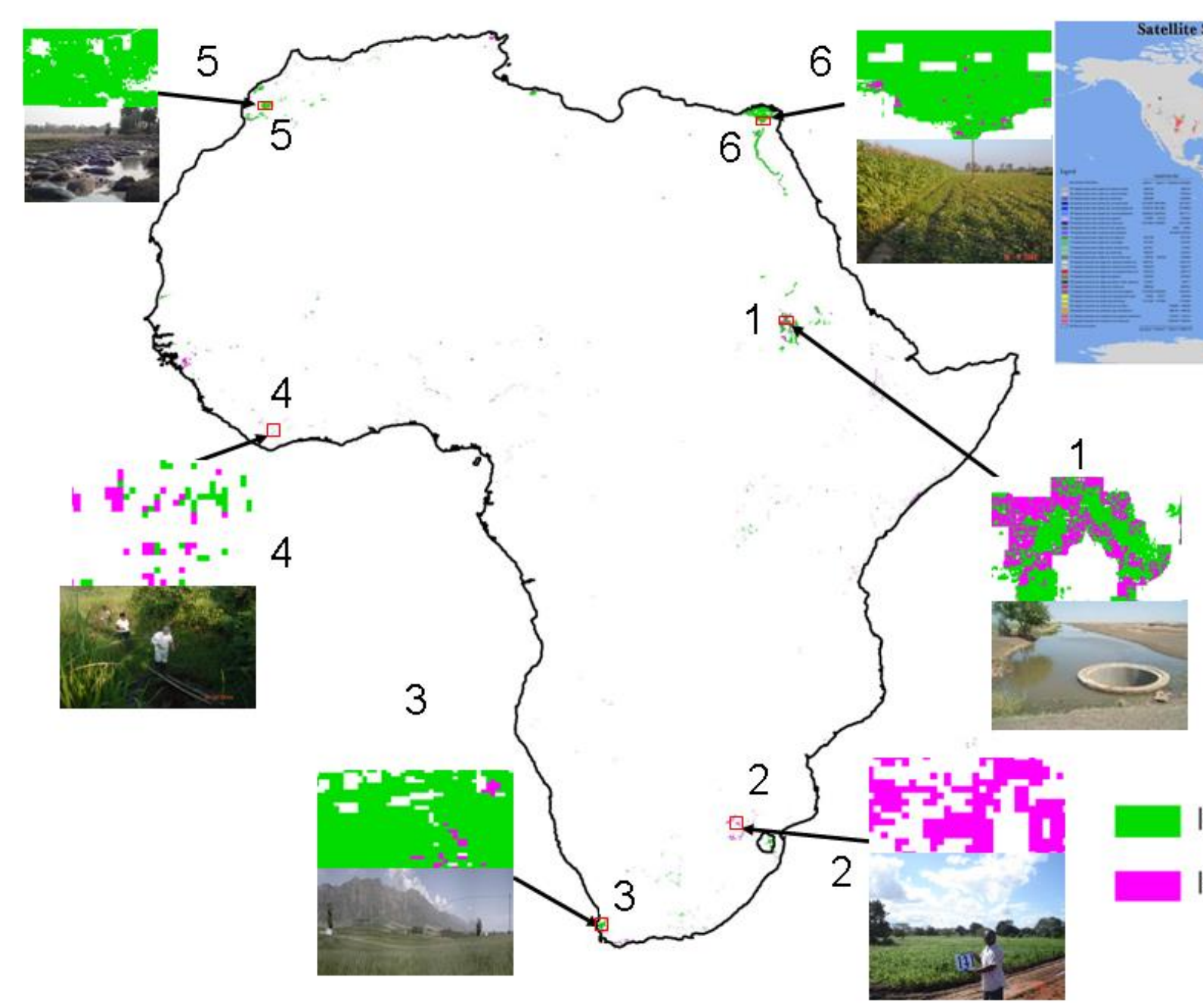

Thenkabail et al., 2009

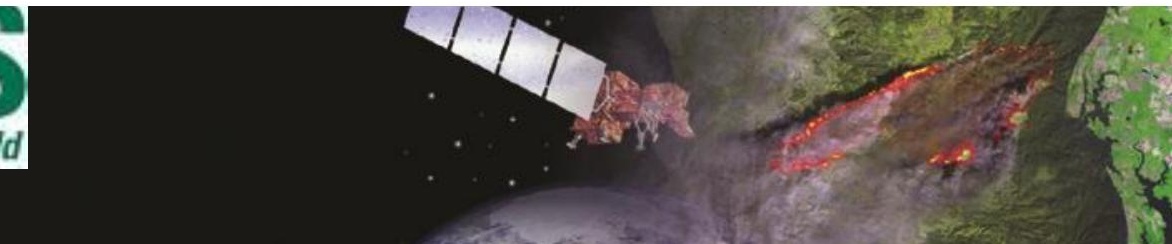

Irrigated cropland areas of Africa. The global annualized irrigated area (AIA) in the African continent is only about $2 \%$ compared to $14 \%$ of the global population. There is a real opportunity to expand irrigated areas in Africa to facilitate green and blue revolutions.

Irrigated, surface water

Irrigated, conjunctive use 
Global Food Security in the $21^{\text {st }}$ Century: Increasing Need of Cropland Areas and Agriculture Water for Food Security Irrigation expansion in Africa?: Contributing to Africa's/Global Food Security

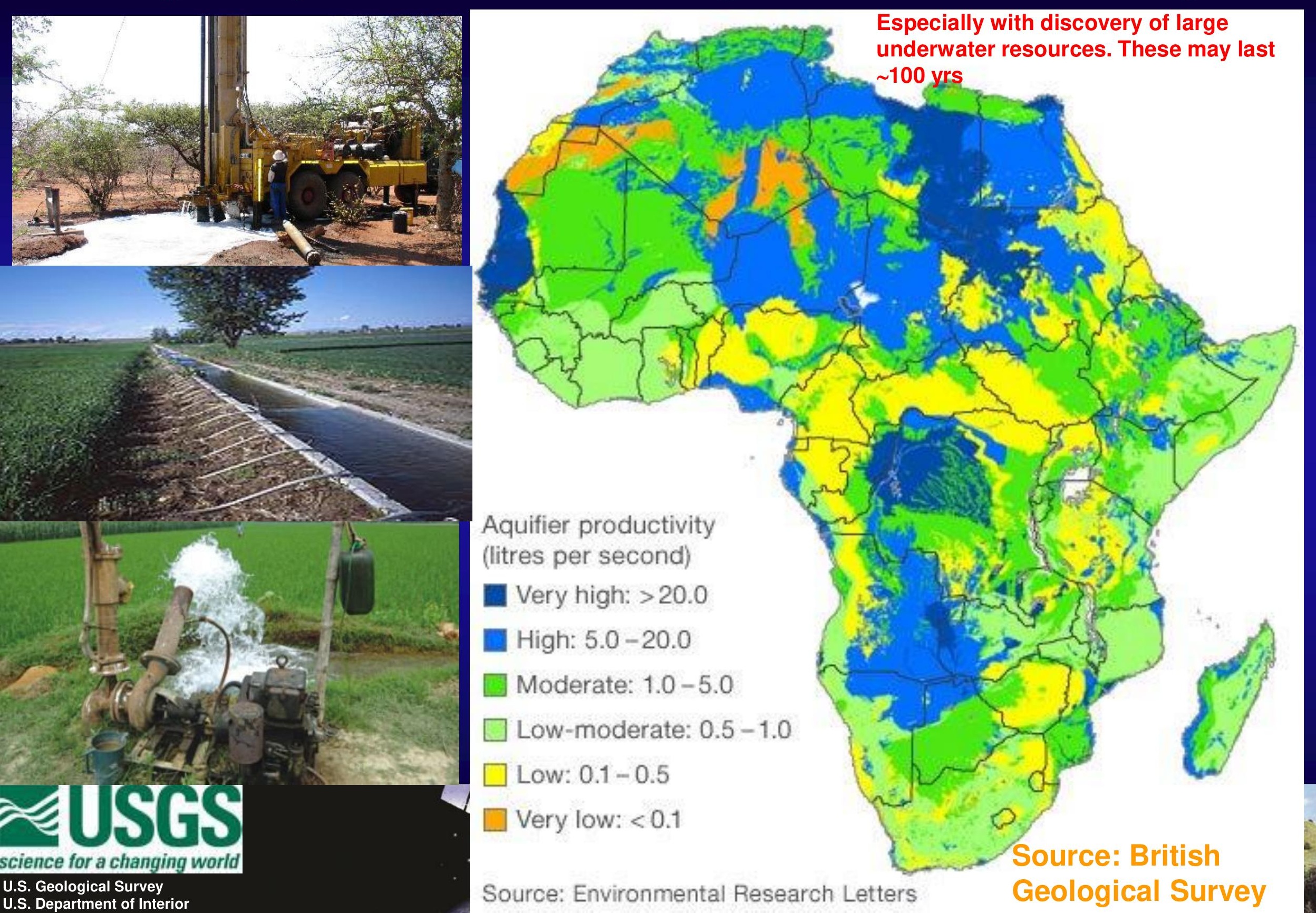



About 30\% ( 1.3 billion tonslyr) of the Food Produced for Human Consumption Goes Waste

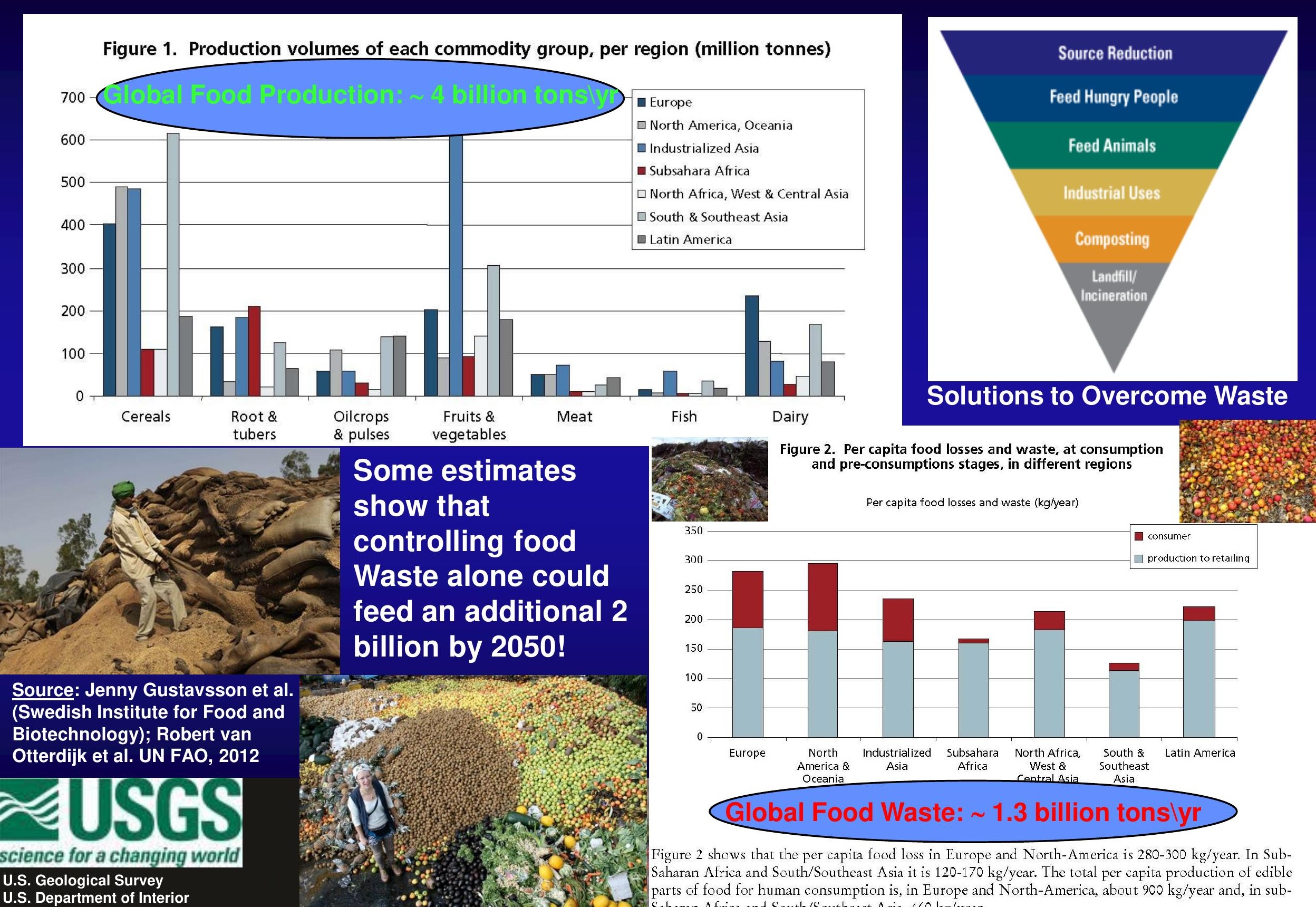


Global Food Security in the 21 $1^{\text {st }}$ Century: Increasing Need of Cropland Areas and Agriculture Water for Food Security African Wetlands: Potential Source of Agricultural Development

The wetlands of Africa are increasingly considered "hotspots" for agricultural development and for expediting Africa's Green and Blue Revolution. Currently, these IV wetlands are un-utilized or highly under-utilized in WCA (Figure) in spite of their rich soils and abundant water availability as a result of:

(a) limited road access to these wetlands, and

(b) prevailing diseases such as Malaria, Trypanosomiasis (sleeping sickness) and Onchocerciasis (river blindness).

However, the utilization of IV wetlands for agriculture is becoming unavoidable in WCA countries due to increasing pressure for food from a ballooning human population and difficulty finding arable land with access to water resources.

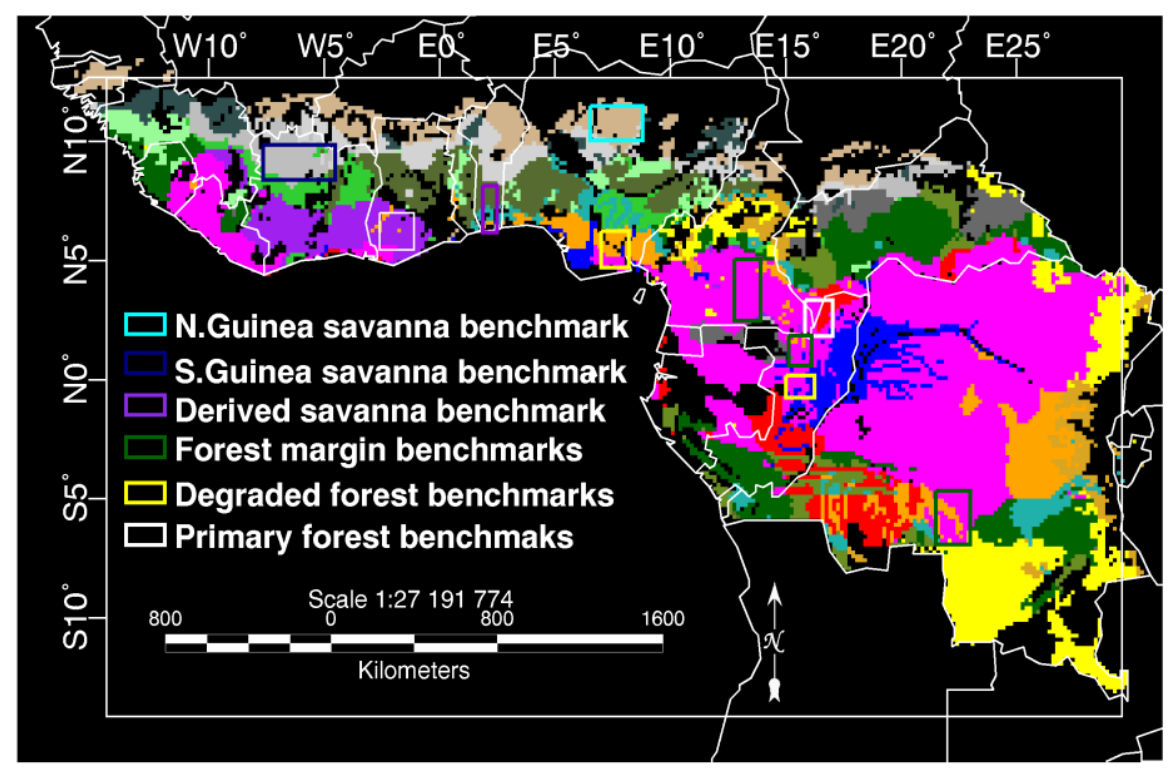

Agroecological and Soil Zones (AESZ) in Humid-forests and savannas of West and Central Africa

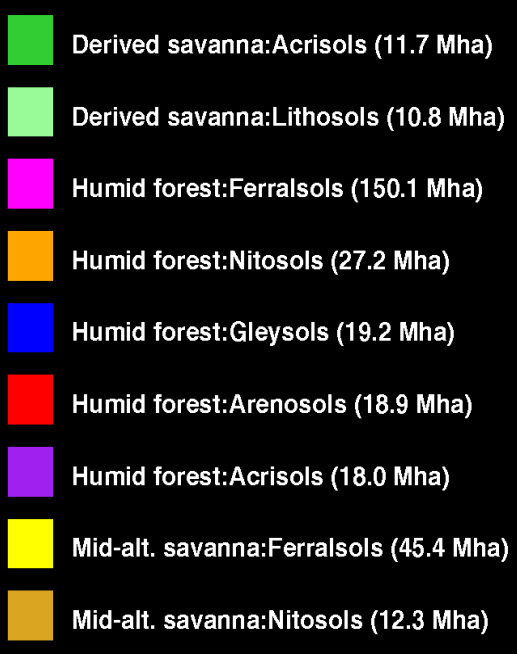

Classification Key
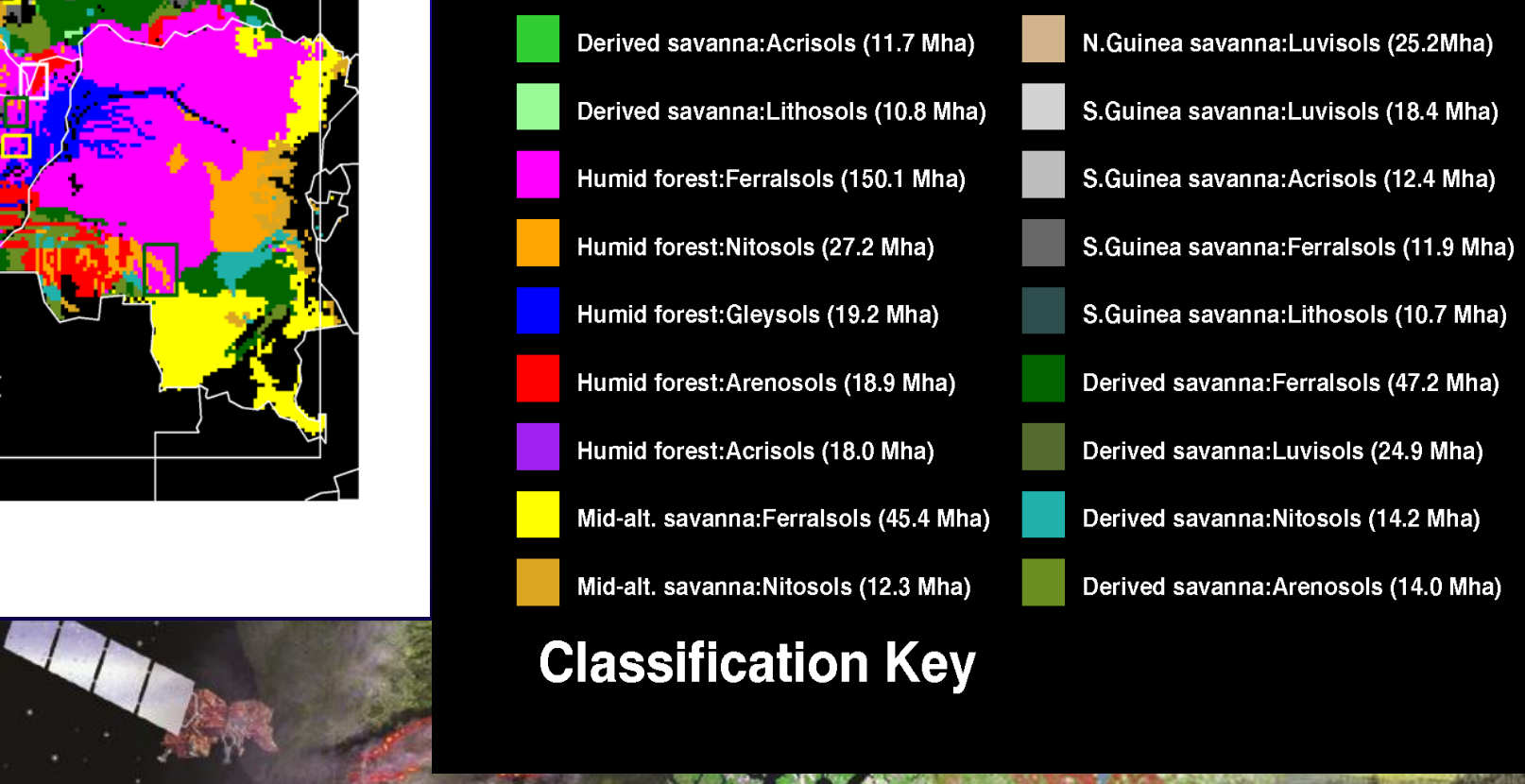
Global Food Security in the $21^{\text {st }}$ Century: Increasing Need of Cropland Areas and Agriculture Water for Food Security African Wetlands: Potential Source of Agricultural Development
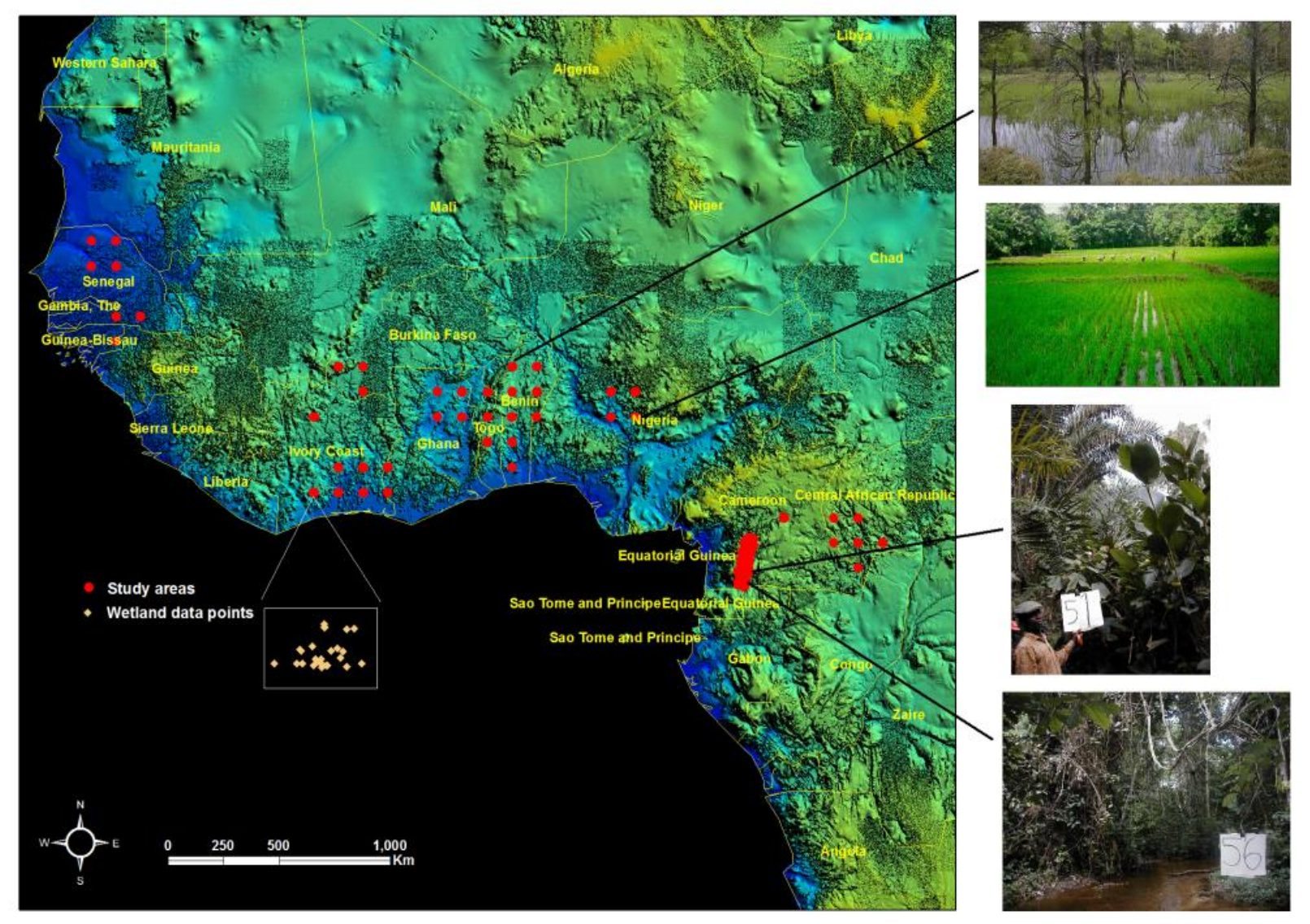

However, we need to Determine Wetlands: (a) Best Suited for cultivation, and (b) Prioritized for Conservation

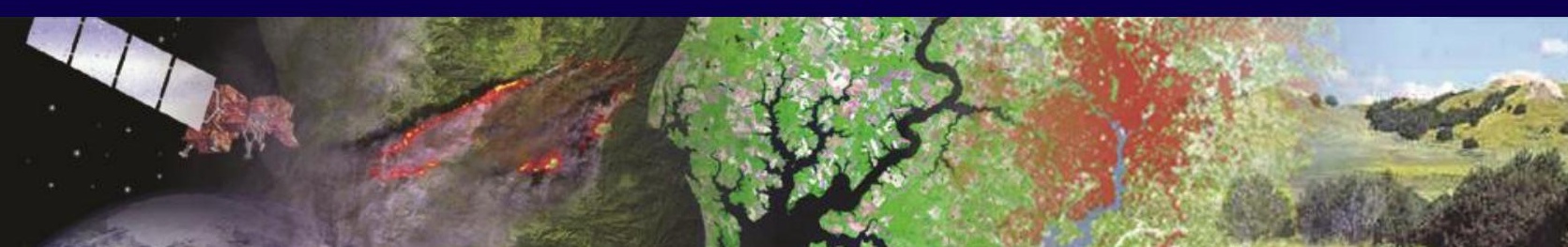


Global Food Security in the 21 $1^{\text {st }}$ Century: Increasing Need of Cropland Areas and Agriculture Water for Food Security Grow Crops that Consume Less Water (e.g., More Wheat than Rice)

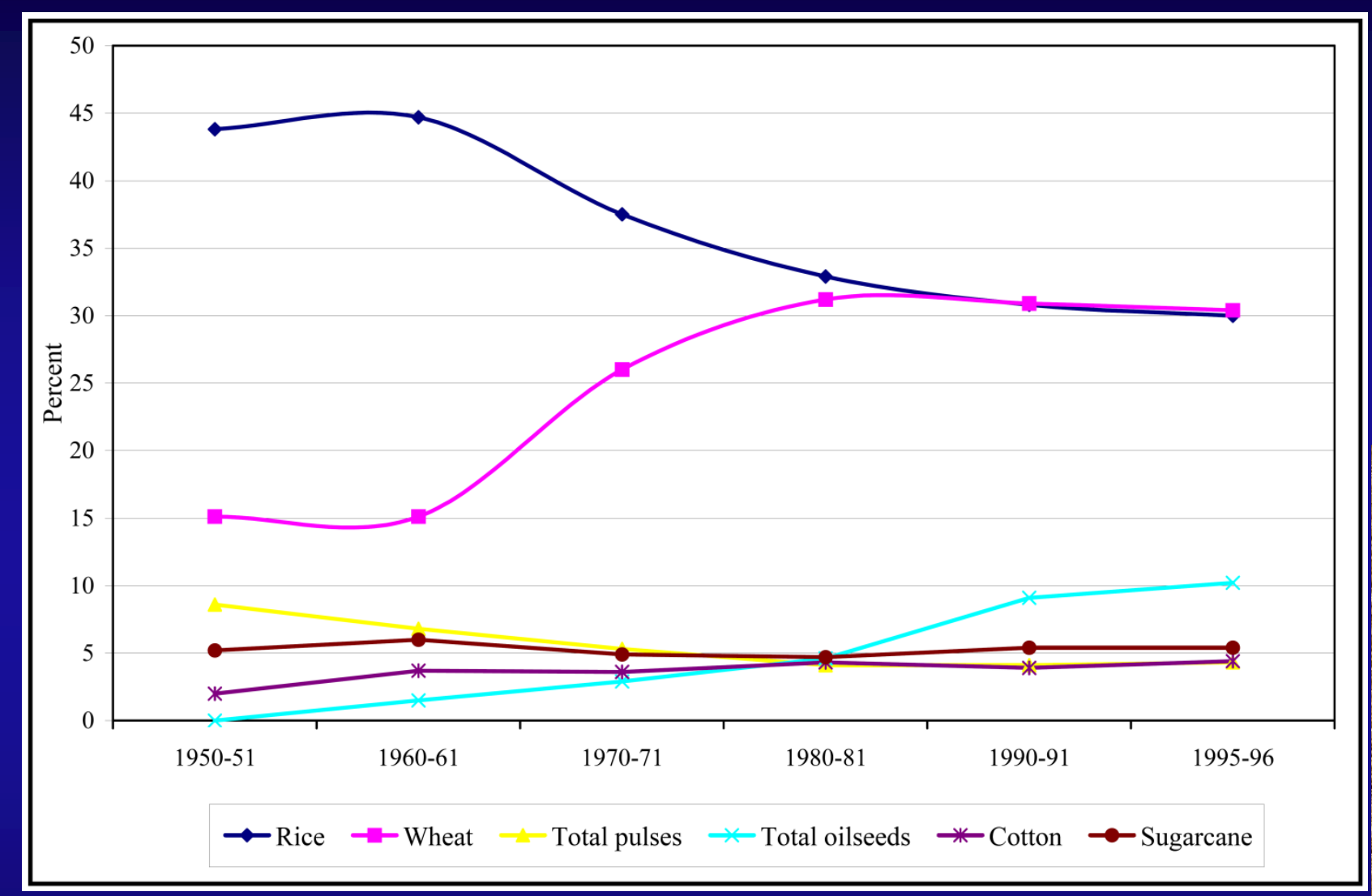

$1 \mathrm{~kg}$ rice requires 1912 liters of water

Currently, India produces about 93 million tonnes of rice per year requiring water of $178 \mathrm{~km}^{3}$. If we convert $50 \%$ of rice area to wheat, we will save about 45 $\mathbf{k m}^{3}$ (45000000000000 liters or 45 trillion liters of water).
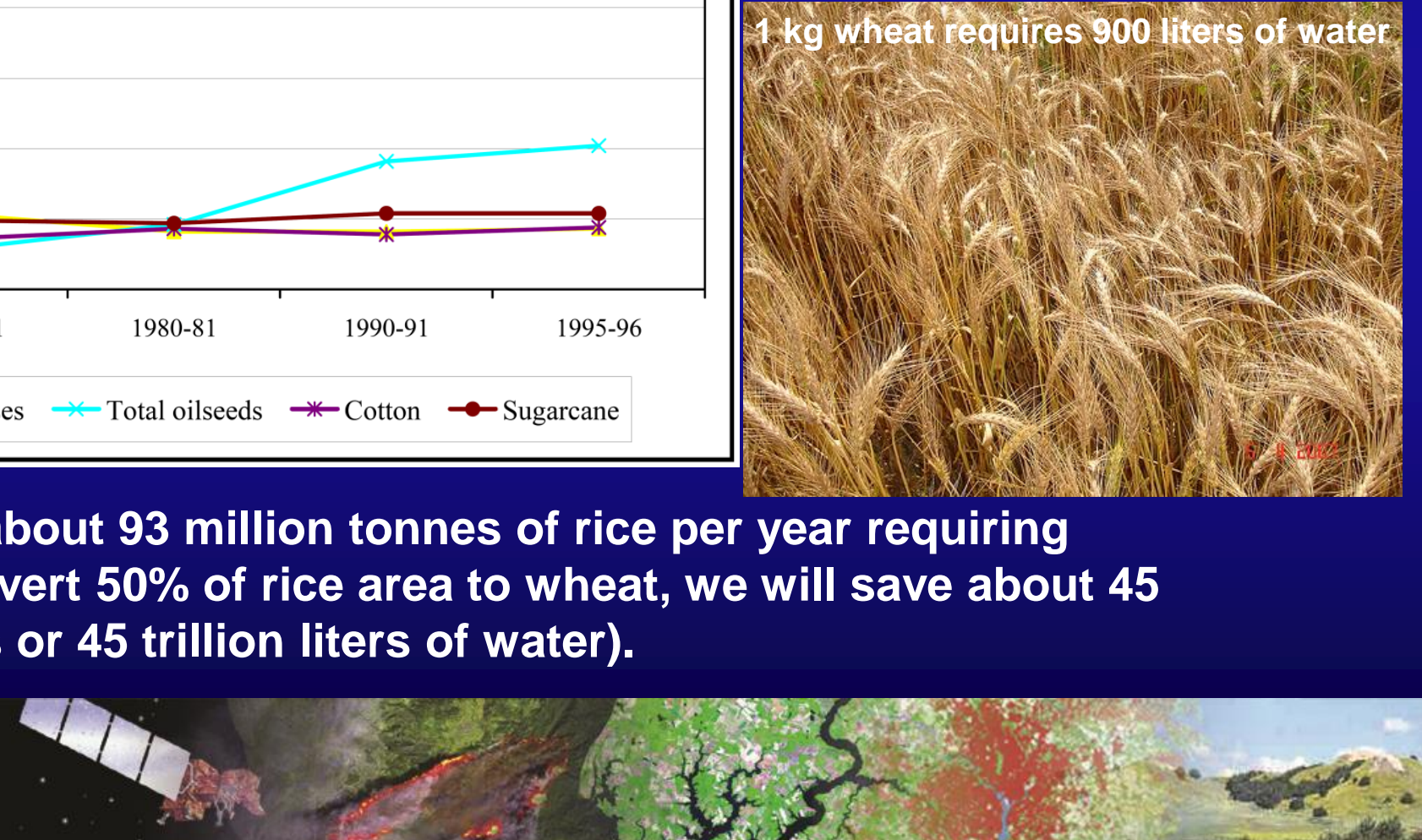

Other measures: Reduce individual and National Waterfootprint

A. Vegetarian

$\begin{array}{ll}\text { Wheat } & 1 \mathrm{~kg} \\ \text { Rice } & 1 \mathrm{~kg} \\ \text { Barley } & 1 \mathrm{~kg} \\ \text { Potato } & 1 \mathrm{~kg} \\ \text { Corn } & 1 \mathrm{~kg} \\ \text { Bread } & 1 \mathrm{slice} \\ \text { Apple } & 1 \mathrm{apple} \\ \text { Cheese } & 1 \mathrm{~kg}\end{array}$

B. Non-Vegetarian

$\begin{array}{ll}\text { Beef } & 1 \mathrm{~kg} \\ \text { Goat meat } & 1 \mathrm{~kg} \\ \text { Chicken } & 1 \\ \text { Egg } & 1 \mathrm{egg}\end{array}$

C. Beverage Coffee Tea Wine Beer
Water footprint (individual)

Global = $1240 \mathrm{~m}^{3} \mid$ yr $\mid$ person

USA $=2480 \mathrm{~m}^{3} \mid$ yrlperson

China $=700 \mathrm{~m}^{3} \mid \mathrm{yr} /$ person

India $=980 \mathrm{~m}^{3} \mid \mathrm{yr} /$ person

1300

900

900

40

70

5000

15500

4000

3900

200

Countries with highest water footprint:

India $=\mathbf{9 8 7}$ trillion cubic meters per year

China $=\mathbf{8 8 3}$ trillion cubic meters per year

USA $=696$ trillion cubic meters per year

Russia $\mathbf{2} \mathbf{2 7 0}$ trillion cubic meters per year Indonesia $\mathbf{2} 269$ trillion cubic meters per year Nigeria $=\mathbf{2 4 8}$ trillion cubic meters per year Brazil $=233$ trillion cubic meters per year

Note: Water foot print can depend on what you produce where (e.g., Virtual water content of cotton will be $5,404 \mathrm{~m} 3 /$ ton if produced in China but 21,563 $\mathrm{m} 3$ /ton if produced in India.)

Source: http://www.waterfootprint.com

Hoekstra, A. Y and Chapagain, A. K., 2007. Water footprints of nations: Water use by people as a function of their consumption pattern. Water Resource Management, 21: 35-48.

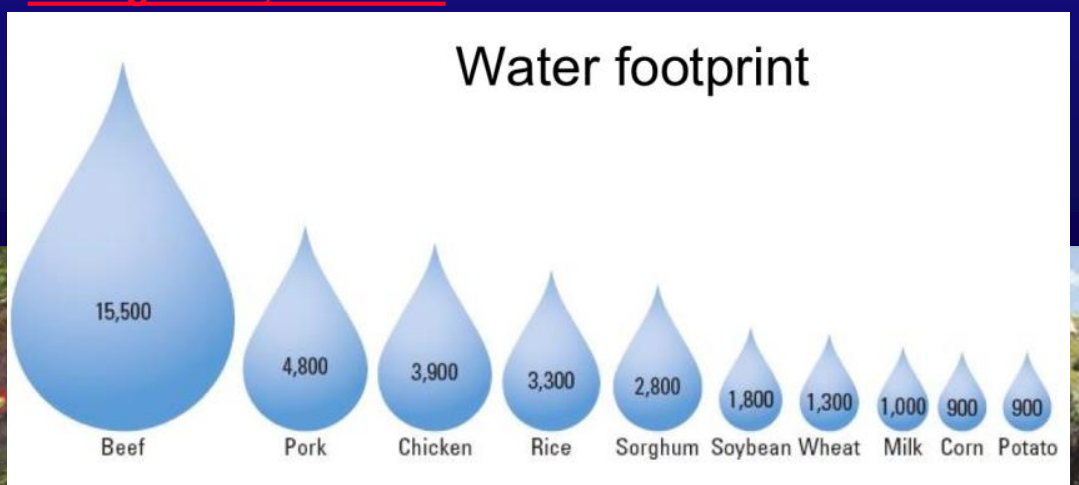


Many other Measures

1. Reduce waste: anywhere between $\mathbf{2 0 - 3 5 \%}$ of all food is wasted;

2. Desalination: okay for urban water use, too costly for irrigation;

3. Water re-use: Reverse osmosis;

4. Better management: desalinization of croplands, precision farming, advanced water management techniques;

.........and many others.

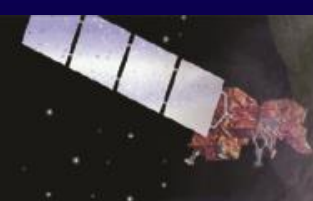




\section{Global Cropland Water Use}

Refierences

U.S. Geological Survey

U.S. Department of Interior 


\section{State-of-Art of Global Croplands and their Water Use}

\section{Inter-linkages between Croplands, their Water use, and Food Security}

Thenkabail P.S., Knox J.W., Ozdogan, M., Gumma, M.K., Congalton, R.G., Wu, Z., Milesi, C., Finkral, A., Marshall, M., Mariotto, I., You, S. Giri, C. and Nagler, P. 2012. Assessing future risks to agricultural productivity, water resources and food security: how can remote sensing help?. Photogrammetric Engineering and Remote Sensing, August 2012 Special Issue on Global Croplands: Highlight Article. Accepted. In press.

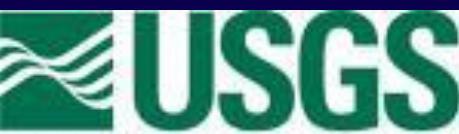

science for a changing world U.S. Geological Survey U.S. Department of Interior
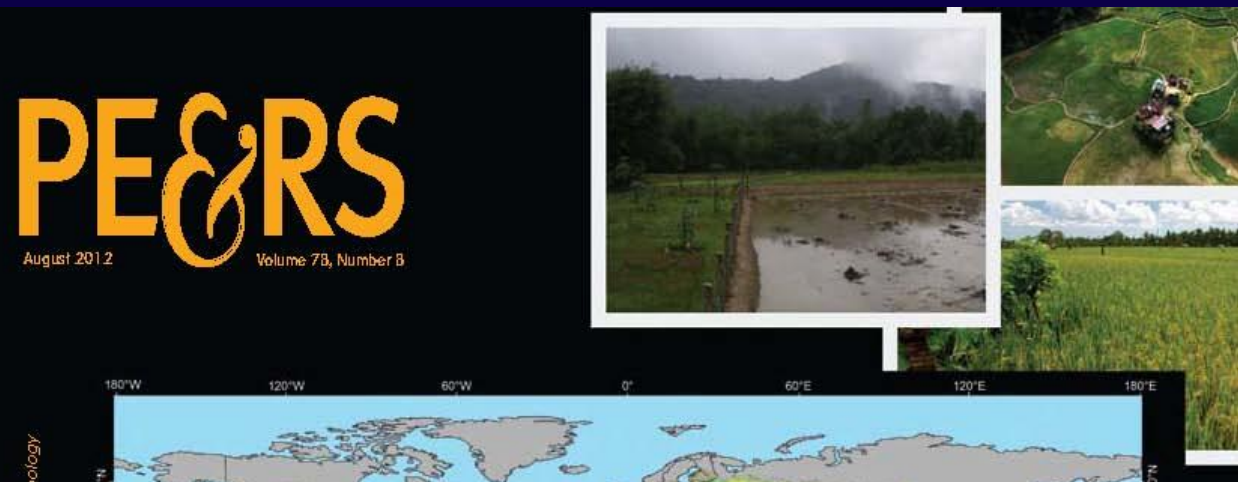

American Society of

Photogrammetry and Remote Sensing (ASPRS) PE\&RS special issue on Global Croplands. August 2012, Vol. 78, No. 8. Guest editor: Thenkabail 


\section{Publications}

\section{Peer review Journal Articles}
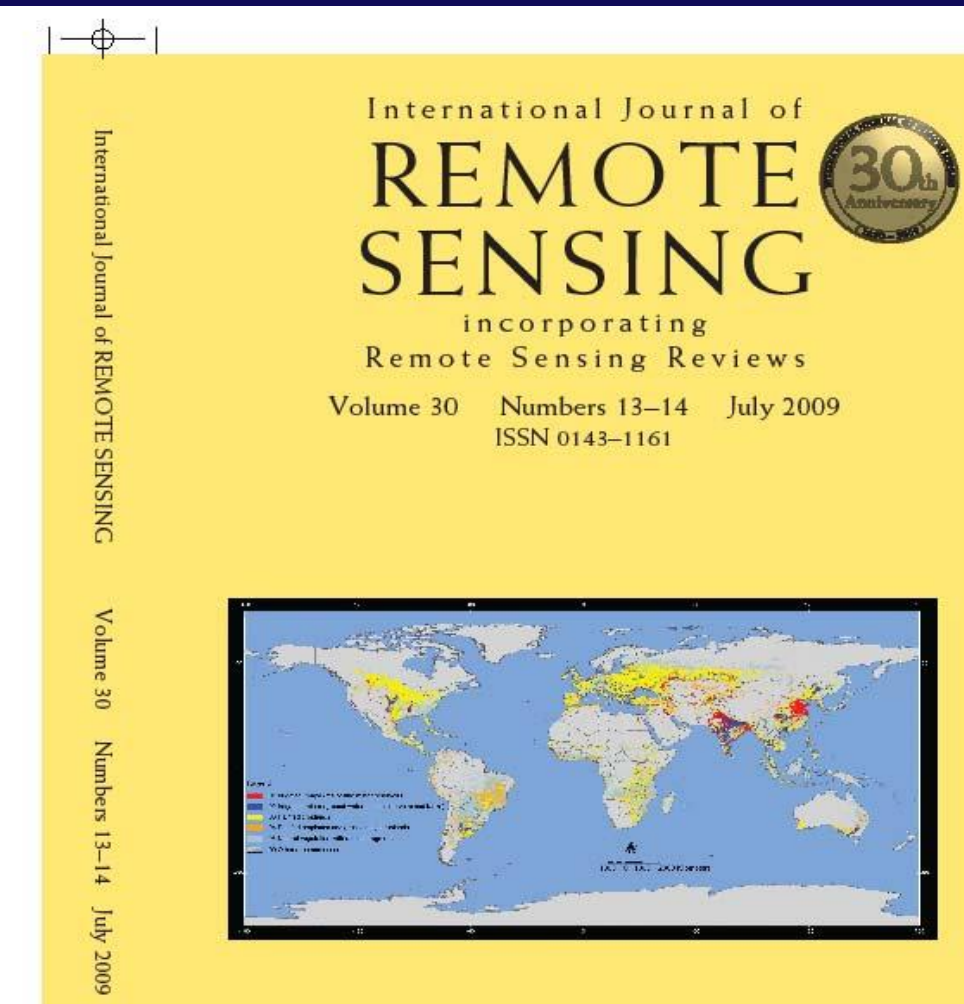

International Journal of REMOTE 30. SENSING incorporating Remote Sensing Reviews

Volume 30 Numbers 13-14 July 2009 ISSN 0143-1161

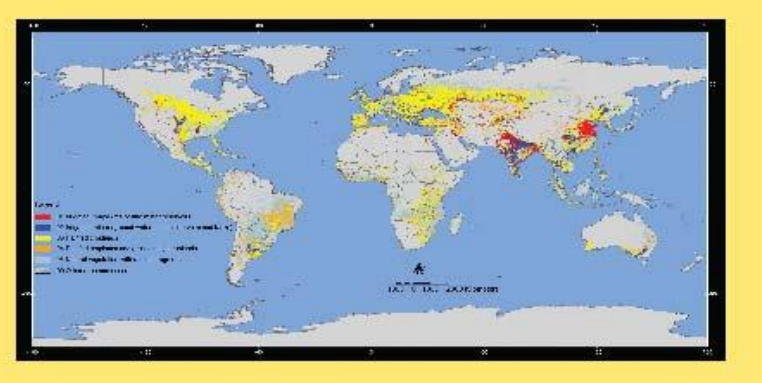

(C)

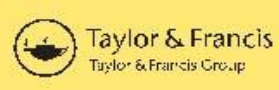

Thenkabail, P.S., Biradar C.M., Noojipady, P., Dheeravath, V., Li, Y.J., Velpuri, M., Gumma, M., Reddy, G.P.O., Turral, H., Cai, X. L., Vithanage, J., Schull, M., and Dutta, R. 2009. Global irrigated area map (GIAM), derived from remote sensing, for the end of the last millennium. International Journal of Remote Sensing. 30(14): 3679-3733. July, 20, 2009.
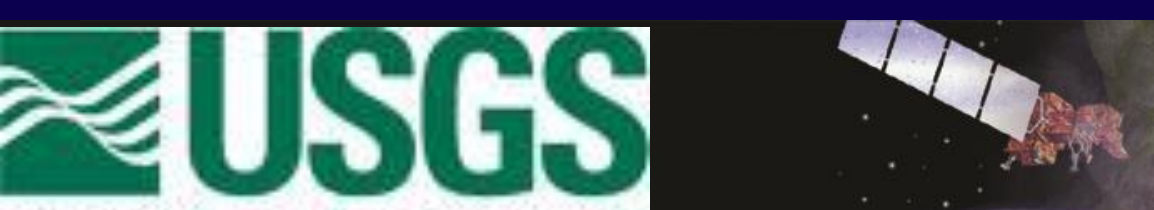


\section{Publications}

Guest Edit a Special Issue on "Global Croplands" for Journal Remote Sensing http://www.mdpi.com/journal/remotesensing/special_issues/croplands

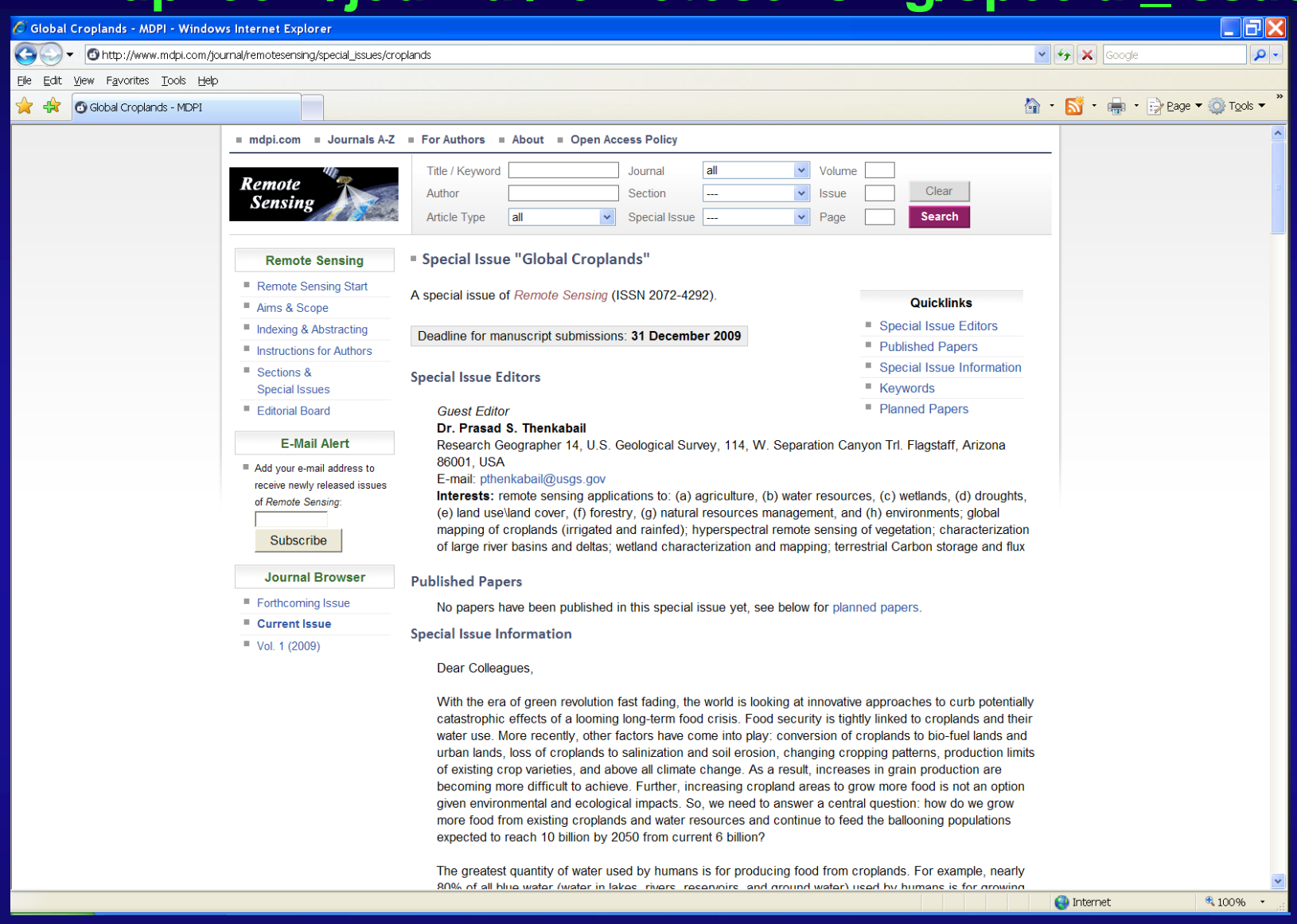

A comprehensive paper on the subject entitled: "A Holistic View of Global Croplands and Their Water Use for Ensuring Global Food Security in the Twenty-First Century through Advance Remote Sensing and Non-Remote Sensing Approaches"' (in review)
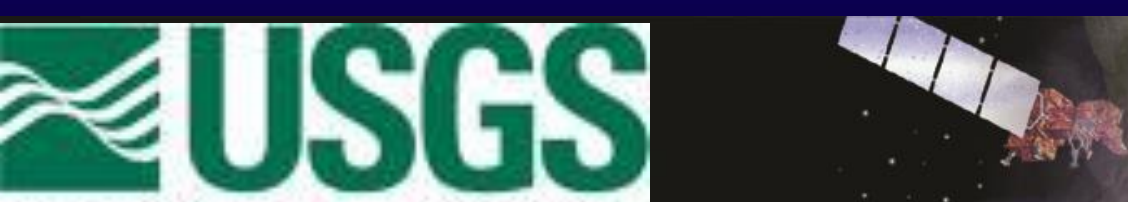
Remote Sensing of Global Croplands for Food Security

\section{Data, Products, Algorithms, Documentations, Manuscripts}

1. Global food security support-analysis data @ 30 m (GFSAD30) web site

http://geography.wr.usgs.gov/science/croplands/index.html

2. Croplands.org for data browsing

http://www.croplands.org/

3. LP DAAC data and products on global croplands

htto://geography.wr.usgs.gov/science/croplands/products.html\#LPDAAC

4. Google Earth Engine (GEE) global croplands

htto://geography.wr.usgs.gov/science/croplands/products.html\#LPDAAC

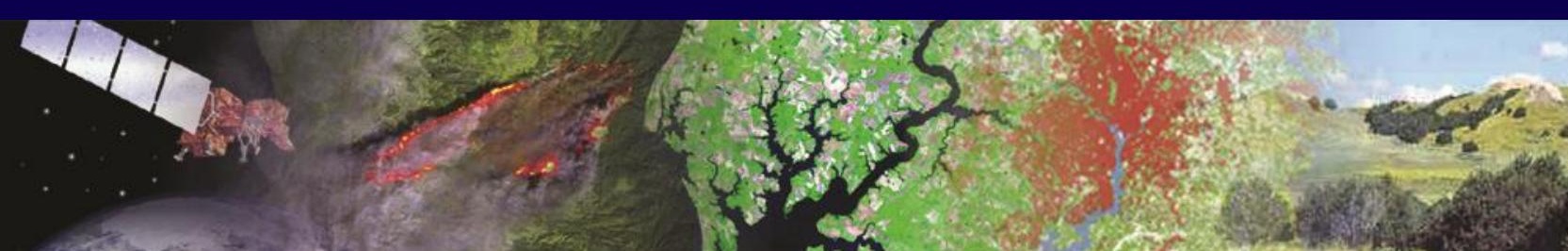

